\title{
MANFAAT PEMBERIAN GELOMBANG ULTRASONIK INTENSITAS RENDAH UNTUK MEMPERCEPAT PEMBENTUKAN KALUS FRAKTUR TIBIA
}

\section{(THE BENEFIT OF LOW INTENSITY ULTRASONIC WAVE TO FASTEN CALLUS FORMATION ON TIBIAL FRACTURES)}

\author{
Sidho Hantoko, Respati Suryanto Dradjat \\ Laboratorium IImu Bedah FK Unibraw-RSU Saiful Anwar Malang
}

\begin{abstract}
Fracture healing relative require more times. Many effort have been done to shorten the time, including stimulation with low intensity ultrasonic. Invitro studies and animal experimentation have been proved in various results. Physical therapy equipments in the hospitals using ultrasonic wave posible to stimulate process of fracture healing. Clinical experimental study was done in our series, the samples was divided randomly into 2 groups. One group was stimulated with low intensity ultrasonic from Sonopuls-591 with 1 $\mathrm{MHz}$ frequency, 0,2 W/cm² intensity, for 15 minutes. The other group withuot stimulation as the control group. The variable were pain, sticky, and callus formation were evaluated perodically. The Results were the degrees of pain in control group higher than control. The bony union (sticky) was no difference within both group. The callus formation was higher in the treatment group ( $p=$ 0,069). Our Conclusion is 15 minutes Low intensity ultrasonic stimulation, that was given 10 times within 3 days time interval was significanly increase callus formation $(p=0,069)$.

Key words: Fracture healing, ultrasonic, callus formation.
\end{abstract}

\begin{abstract}
ABSTRAK
Proses penyembuhan fraktur memerlukan waktu yang relatif lama. Banyak usaha yang telah dilakukan untuk mempercepat penyembuhan fraktur. Salah satunya adalah memberikan rangsang gelombang ultrasonik intensitas rendah. Penelitian invitro dan binatang percobaan telah dilakukan dengan hasil yang bervariasi. Di rumah sakit pemerintah tersedia alat fisioterapi gelombang ultrasonik yang diharapkan dapat digunakan untuk mempercepat penyembuhan fraktur. Dilakukan penelitian eksperimental klinis, secara random sampel dibagi menjadi 2 kelompok. Kelompok perlakuan diberikan gelombang ultrasonik intensitas rendah dari mesin Sonopuls-591 dengan frekuensi $1 \mathrm{MHz}$, intensitas 0,2 W/cm², selama 15 menit. Sebagai pembanding adalah kelompok kontrol. Parameter yang dinilai adalah kecepatan hilangnya nyeri, kecepatan sticky dan ketebalan kalus. Dari hasil penelitian didapatkan derajat nyeri pada kontrol cenderung lebih tinggi dibandingkan dengan perlakuan Hasil penilaian sticky tidak terdapat perbedaan antara perlakuan dan kontrol. Kalus yang terbentuk pada perlakuan cenderung lebih tinggi dibandingkan dengan pada kontrol $(p=$ 0,069). Dapat disimpulkan bahwa pemberian gelombang ultrasonik intensitas rendah selama 15 menit, sebanyak 10 kali dan selang waktu antar pemberian 3 hari pada fraktur tibia yang ditatalaksana secara konservatif terbukti dapat mempercepat pembentukan kalus $(p=0,069)$.
\end{abstract}

Kata kunci: Penyembuhan fraktur, gelombang ultrasonik, pembentukan kalus

\section{PENDAHULUAN}

Trauma yang mencederai tulang, menempati tempat teratas yang menyebabkan pasien datang untuk minta pertolongan ke rumah sakit. Di Rumah Sakit Saiful Anwar Malang tahun 1999-2002 tercatat rata-rata 5 kasus fraktur datang minta pertolongan setiap hari. Sebagian besar korban (40-45\%) yang datang adalah usia produktif (25-40 tahun) (1). Dengan demikian akan menurunkan produktifitas kerja, karena memerlukan waktu yang cukup lama (3-16 minggu) untuk bisa kembali ke kondisi semula.

Saat ini sedang dikembangkan usaha untuk mempercepat penyembuhan fraktur dengan menggunakan rangsang mekanik berupa pemberian gelombang ultrasonik. Telah banyak dilakukan penelitian mulai dari penelitian in vitro, binatang percobaan maupun dengan manusia dengan berbagai intensitas dan lama pemberian. Hasilnya beragam, secara umum dibuktikan gelombang ultrasonik dapat mempercepat pembentukan kalus $(2,3,4,5,6,7,8,9,10,11,12,13,14)$.

Pada penelitian dengan manusia telah dilakukan pada tulang radius distal, tulang hamatum, tulang humerus, tulang klavikula, tulang skafoid dan tulang tibia $(6,7,8,11,14)$. Pada penelitian pada tulang tibia, gelombang ultrasonik memberikan hasil paling nyata dalam mempercepat pembentukan kalus $(7,10)$. Hal ini dapat dijelaskan bahwa pada pemberian gelombang ultrasonik, besarnya efek pada jaringan sesuai dengan besarnya energi yang diserap oleh jaringan tersebut.

Intensitas gelombang ultrasonik yang diterima jaringan bergantung pada jarak ujung pemancar gelombang ultrasonik (probe) dengan jaringan sasaran dan jenis jaringan yang dilalui gelombang (15). 
Pengelompokan intensitas gelombang ultrasonik ada beberapa pendapat, tetapi sebagian besar membagi dalam: intensitas rendah $\left(<0,3 \mathrm{~W} / \mathrm{cm}^{2}\right)$, intensitas sedang $(0,3-1,2$ $\left.\mathrm{W} / \mathrm{cm}^{2}\right)$, intensitas tinggi $\left(1,2-3 \mathrm{~W} / \mathrm{cm}^{2}\right)$ dan intensitas sangat tinggi $\left(>3 \mathrm{~W} / \mathrm{cm}^{2}\right)(15)$.

Pada penelitian klinis sebelumnya telah banyak dilaporkan tentang penggunaan gelombang ultrasonik intensitas rendah untuk mempercepat penyembuhan fraktur dengan hasil yang bervariasi (terjadi pencepatan 28\% - 45\%) $(2,7,8)$. Dradjat melaporkan pada kultur osteoblas yang dirangsang dengan gelombang ultrasonik frekuensi $1 \mathrm{MHz}$, intensitas $2 \mathrm{~W} / \mathrm{cm}^{2}$ mengakibatkan kerusakan atau kematian sel, sedangkan perangsangan dengan menggunakan frekuensi $1 \mathrm{MHz}$, intensitas $0,2 \mathrm{MHz}$ meningkatkan aktifitas seluler (1). Penelitian in vitro lainnya yang menggunakan intensitas sangat tinggi (20 - 120 $\left.\mathrm{W} / \mathrm{cm}^{2}\right)$ didapatkan peningkatan aktifitas seluler $(2,13,16,17,18,19)$.

Penelitian yang banyak dilakukan dinegara-negara maju menggunakan alat yang khusus dirancang untuk tujuan ini, disebut Sonic Accelerated Fracture Healing System (SAFHS). Dengan alat ini diberikan gelombang ultrasonik intensitas rendah selama 10-20 menit/hari. Hasil terbaik (pencepatan 45\%) didapatkan pada pemberian 20 menit/hari $(2,5,6,7,8,10)$. Di Indonesia alat semacam ini belum tersedia, sehingga untuk penelitian ini digunakan mesin Sonopuls-591, suatu alat yang sebelumnya hanya dipakai untuk fisioterapi kasus-kasus nyeri otot, sinusitis, kaku sendi dan belum pernah digunakan untuk mempercepat penyembuhan fraktur. Alat ini menggunakan frekuensi $1 \mathrm{MHz}$, intensitas dapat diatur $(0,2 ; 1 ; 1,5) \mathrm{W} / \mathrm{cm}^{2}$ dan waktu dapat diatur $(5,10,15)$ menit (15). Alat ini dimiliki oleh Rumah Sakit Pemerintah minimal tipe $\mathrm{C}$.

Untuk menjelaskan masalah dan berbagai dugaan yang sudah diuraikan, maka dilakukan penelitian ini. Apakah rangsang gelombang ultrasonik intensitas rendah dari mesin Sonopuls-591 dengan frekuensi $1 \mathrm{MHz}$, intensitas $0,2 \mathrm{~W} / \mathrm{cm}^{2}$, selama 15 menit dapat mempercepat pembentukan kalus fraktur tibia?

Tujuan penelitian ini adalah membuktikan manfaat rangsang gelombang ultrasonik intensitas rendah dari mesin Sonopuls-591 dengan frekuensi $1 \mathrm{MHz}$, intensitas $0,2 \mathrm{~W} / \mathrm{cm}^{2}$, selama 15 menit untuk mempercepat pembentukan kalus fraktur tibia.

Jika pada penelitian ini terbukti maka, dapat menambah khazanah teori tentang penyembuhan fraktur dan menambah bukti yang sudah ada tentang konsep pengaruh mekanik pada biologi sel tulang. Sehingga hasil penelitian ini dapat digunakan untuk mengembangkan protokol baru dalam penatalaksanaan fraktur, dapat digunakan untuk memperbaiki kelainan tulang yang lain, berkaitan dengan penggunaan gelombang ultrasonik intensitas rendah untuk mempercepat osteogenesis pada kelainan tulang yang lain.

\section{METODE PENELITIAN}

\section{Rancangan penelitian}

Rancangan penelitian ini adalah Studi klinis kasus kelola (Case control experimental study). Pembagian kelompok perlakuan dan kelompok kontrol dilakukan secara random.
Perlakuan diberikan kepada kelompok $\mathrm{P}$, berupa pemberian gelombang ultrasonik intensitas rendah, dengan frekuensi $1 \mathrm{MHz}$, intensitas $0,2 \mathrm{~W} / \mathrm{cm}^{2}$, selama 15 menit, sebanyak 10 kali, dengan selang waktu 3 hari, dimulai hari ke 7 pasca reposisi dan imobilisasi.

Rangsang gelombang ultrasonik diberikan melalui probe dari alat Sonopuls-591, ditempelkan pada kulit diatas fraktur, melewati jendela gips seluas $7 \times 10 \mathrm{~cm}$ dengan perantaraan jelly sebagai penghantar rangsangan.

Variabel bebas adalah rangsang tekanan mekanik berupa gelombang ultrasonik intensitas rendah dengan frekuensi $1 \mathrm{MHz}$, intensitas $0,2 \mathrm{~W} / \mathrm{cm}^{2}$ yang diberikan selama 15 menit, sebanyak 10 kali, dengan selang waktu 3 hari, dimulai hari ke 7 melewati jendela gips.

Variabel tergantung adalah 1) hilangnya nyeri, dinilai dengan menggunakan skala kuantifikasi nyeri dari Wong Baker Faces Pain Scale, 2) stabilitas fraktur, ditentukan dengan pemeriksaan klinis, dan 3) kalsifikasi, ditentukan dengan pemeriksaan Rontgen AP dan lateral untuk melihat kalus sekunder.

Kelompok kontrol adalah fraktur tibia dengan kriteria yang sama dengan kelompok yang diberi perlakuan, tetapi tidak diberikan rangsang gelombang ultrasonik intensitas rendah.

Alat ultrasonik menggunakan mesin Sonopuls-591, buatan Belanda merupakan alat ultrasonik untuk fisioterapi, besar rangsangan dapat diatur sesuai dengan intensitas dan lama waktu yang dikehendaki.

Alat foto rontgen yang digunakan adalah Hitachi Sirius 80N-UG-4LF-03TB, buatan Jepang, dapat diatur Kv dan mA sesuai dengan yang dikehendaki.

\section{Subyek penelitian}

Sampel adalah seluruh penderita fraktur tibia tertutup yang ditangani awal di IRD RSSA Malang.

Hari ke 1 dilakukan foto rontgen pra dan pasca reposisi sebagai kontrol, reposisi dan imobilisasi dengan gips sirkuler long leg cast (diberikan tanda untuk pembuatan window dipoliklinik) dan diberikan analgetik.

Kelompok perlakuan diberi rangsang gelombang ultrasonik intensitas rendah, sebanyak 10 kali, dengan selang waktu 3 hari, dimulai hari ke 7. Minggu IV, VIII, XII dilakukan foto rontgen.

\section{Kriteria inklusi}

Semua pasien laki-laki, usia 20-30 tahun yang dengan pemeriksaan klinis didiagnosa dengan fraktur tibia simpel, tanpa disertai trauma lain sebagai sumber rasa nyeri yang lain (trauma tunggal).

\section{Kriteria eksklusi}

1. Radiologis:

- Panjang garis fraktur lebih 2 kali diameter diafisis (long spiral atau long oblique).

- Beranjak lebih dari $50 \%$ lebar diafisis.

- Gap lebih dari 0,5 cm.

2. Fraktur tibia terbuka.

3. Fraktur metafisis.

4. Fraktur dengan pemendekan yang menetap lebih dari $1 \mathrm{~cm}$ setelah reposisi.

5. Tidak stabil (angulasi menetap atau berulang 10 derajat atau lebih). 
Hal.

6. Fraktur dengan fragmen butterfly besar (lebih dari 2 kali diameter diafisis).

7. Fraktur patologis.

8. Fraktur kominutif.

9. Sedang dalam terapi steroid, antikoagulan, obat anti inflamasi non steroid, Ca channel blocker.

10. Riwayat tromboflebitis, insufisiensi vaskuler.

11. Defisiensi nutrisi.

12. Perokok dan atau peminum alkohol.

Sampel yang memenuhi persyaratan diminta untuk mengisi inform concent.

Jumlah sampel

Jumlah sampel dalam penelitian ini ditentukan dengan Rule of Thumb:

$$
n \geq 16 /(p-1)
$$

Keterangan: $n=$ jumlah sampel

$p=$ jumlah perlakuan

Jumlah sampel masing-masing kelompok $\geq 16$

\section{Cara pengambilan sampel}

Semua pasien fraktur tibia tertutup, yang dilakukan penatalaksanaan secara non operatif, setelah dilakukan pemeriksaan klinis dan radiologis memenuhi syarat diberikan informed consent (penjelasan dan setuju untuk berpartisipasi dalam penelitian ini) dicatat identitas, dilakukan penatalaksanaan sesuai protokol.

Pengambilan sampel dengan memperhatikan kriteria inklusi dan eksklusi dan ditentukan secara random sebagai kelompok perlakuan atau kontrol.

\section{Prosedur pengambilan dan pengumpulan data}

Data dikumpulkan mulai pasien masuk di IRD sampai minggu ke 12, setelah dilakukan foto rontgen. Dicatat tindakan yang dilakukan dan juga hasilnya.

\section{Cara analisis data}

Pengamatan klinis untuk pemeriksaan nyeri dan stabilitas diperiksa oleh peneliti. Pengamatan hasil foto rontgen pra dan pasca perlakuan dilakukan oleh peneliti dan ahli radiologi. Uji konsistensi dilakukan dengan Anova.

\section{Uji statistik}

Untuk membedakan hasil yang diperoleh pada kelompok kontrol dan kelompok perlakuan menggunakan analisis nonparametrik dengan menggunakan Mann-Whitney Test.

Bila sampai waktu pengamatan terlewati dan $p$ value $>0,05$ maka akan dilakukan analisis dengan model regresi non linier untuk memprediksi $p$ value dikaitkan dengan waktu dalam minggu.

$$
\begin{gathered}
p \text { value }=3,341421798 \cdot e^{-0,319951197 M} \\
R^{2}=0,9999 \text { dan } p=0,0000
\end{gathered}
$$

\section{Penilaian Klinis}

Nyeri tekan dan tarik sesuai sumbu panjang tulang diperiksa oleh satu orang peneliti, evaluasi dilakukan pada saat kunjungan poliklinik yang telah ditentukan. Untuk menilai derajat nyeri dipakai skala kuantifikasi nyeri menurut Wong Baker (20).

Nilai 0 : Tidak ada keluhan nyeri sama sekali, tampak bahagia, bisa tertawa lepas

Nilai 1 : Tidak ada keluhan nyeri, tampak tersenyum
Nilai 2 : Tidak ada keluhan nyeri, ekspresi datar

Nilai 3 : Merasa nyeri, tetapi masih bisa menahan

Nilai 4 : Merasa nyeri, tidak bisa menahan

Nilai 5 : Nyeri hebat, sampai keluar air mata

Untuk menilai sticky dilakukan dengan menggerakkan fragmen distal, dinyatakan sticky bila pada waktu fragmen distal digerakkan fragmen proksimal tidak ikut bergerak, penilaian ini dilakukan oleh satu orang peneliti.

\section{Radiologis}

Penilaian radiologis dilakukan untuk menilai kemajuan penyembuhan, melalui penampakan kalus pada gambar rontgen. Parameter pada evaluasi radiologis adalah melaui kuantifikasi kalus yang terbentuk, dilakukan oleh satu orang spesialis radiologi, dengan alat yang sama, jarak, Kv, mA yang disesuaikan.

Nilai 0 : Tidak tampak adanya perubahan pada kortek dibanding foto rontgen inisial

Nilai 1: Tampak reaksi periosteal pada sisi fraktur

Nilai 2: Tampak reaksi periosteal lengkap menghubungkan kedua kortek

Nilai 3 : Garis fraktur mulai menghilang

Nilai 4: Mulai terbentuk kalus dengan densitas lebih rendah dibanding tulang yang sehat

Nilai 5 : Kalus telah lengkap terbentuk dengan densitas sama dengan tulang yang sehat.

\section{HASIL PENELITIAN DAN PEMBAHASAN}

Hasil

Pemeriksaan nyeri pada perlakuan dan kontrol didapatkan hasil sebagai berikut (tabel 1)

Tabel 1. Perbandingan antara perlakuan dan kontrol dari hasil pemeriksaan nyeri.

\begin{tabular}{|c|c|c|c|c|c|c|c|c|c|c|}
\hline & \multicolumn{1}{|c|}{$\begin{array}{c}\text { MINGGU } \\
\text { IV }\end{array}$} & \multicolumn{3}{c|}{$\begin{array}{c}\text { MINGGU } \\
\text { VIII }\end{array}$} & \multicolumn{3}{c|}{$\begin{array}{c}\text { MINGGU } \\
\text { XII }\end{array}$} & $\begin{array}{c}\text { JML } \\
\text { SAMPEL }\end{array}$ \\
\cline { 1 - 9 } NILAI SKALA NYERI & $\mathbf{4}$ & $\mathbf{3}$ & $\mathbf{2}$ & $\mathbf{3}$ & $\mathbf{2}$ & $\mathbf{1}$ & $\mathbf{2}$ & $\mathbf{1}$ & $\mathbf{0}$ & \\
\hline PERLAKUAN & 1 & 2 & 13 & 1 & 2 & 13 & 0 & 8 & 8 & 16 \\
\hline KONTROL & 2 & 6 & 9 & 2 & 4 & 11 & 0 & 11 & 6 & 17 \\
\hline
\end{tabular}

Terdapat penurunan rasa nyeri lebih banyak pada kelompok perlakuan dibandingkan kelompok kontrol.

Pengukuran nyeri yang digunakan adalah skala kuantifikasi nyeri menurut Wong Baker, dimana data yang dihasilkan berupa data ordinal. Oleh karena itu, untuk mengetahui efek perlakuan pemberian gelombang ultrasonik intensitas rendah terhadap nyeri dianalisis secara Nonparametrik dengan MannWhitney Test. Nilai Rank dan $p$ value hasil pengujian tersebut dapat dilihat pada Tabel 2.

Tabel 2. Nilai Rank dan $p$ value hasil Mann-Whitney Test untuk variabel nyeri

\begin{tabular}{|c|c|c|c|c|}
\hline Nyeri & Group & $\mathrm{N}$ & Mean Rank & $p$ value \\
\hline \multirow{2}{*}{ Minggu IV } & Kontrol & 17 & 19.21 & \multirow{2}{*}{0.104} \\
\cline { 2 - 4 } & Perlakuan & 16 & 14.66 & \\
\hline \multirow{2}{*}{ Minggu VIII } & Kontrol & 17 & 18.32 & \multirow{2}{*}{0.299} \\
\cline { 2 - 4 } & Perlakuan & 16 & 15.59 & \\
\hline
\end{tabular}




\begin{tabular}{|c|c|c|c|c|}
\hline \multirow{2}{*}{ Minggu XII } & Kontrol & 17 & 18.18 & \multirow{2}{*}{0.400} \\
\cline { 2 - 4 } & Perlakuan & 16 & 15.75 & \\
\hline
\end{tabular}

Hasil penelitian seperti pada Tabel 2 menunjukkan bahwa derajat nyeri pada kontrol cenderung lebih tinggi dibandingkan dengan pada perlakuan. Hal lain yang dapat diketahui adalah bahwa derajat perbedaan nyeri pada minggu awal (minggu IV) lebih tinggi $(p=0.104)$ dibandingkan dengan pada minggu akhir (minggu XIl; $p=0.400$ ). Perbedaan tersebut secara visual dapat dilihat pada Gambar 1 dan 2
Untuk mengetahui efek perlakuan pemberian gelombang ultrasonik intensitas rendah terhadap pembentukan kalus dianalisis secara Nonparametrik dengan Mann-Whitney Test. Nilai Rank dan $p$ value hasil pengujian tersebut dapat dilihat pada Tabel 4.

Tabel 4. Nilai Rank dan $p$ value hasil Mann-Whitney Test
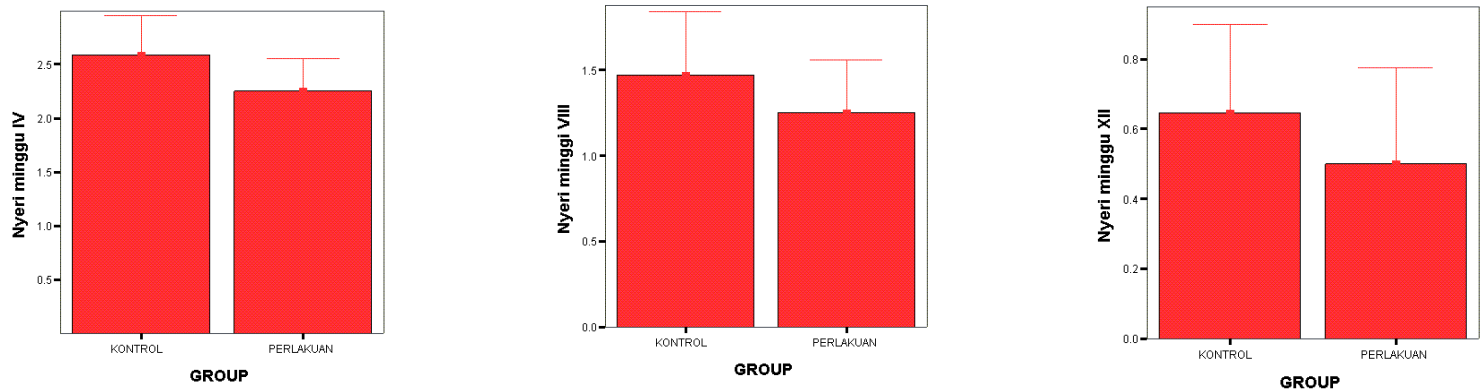

Gambar 1. Histogram variabel nyeri pada perlakuan dan kontrol

Penurunan rasa nyeri secara signifikan terjadi pada minggu ke IV dibandingkan dengan minggu ke VII atau minggu ke XII
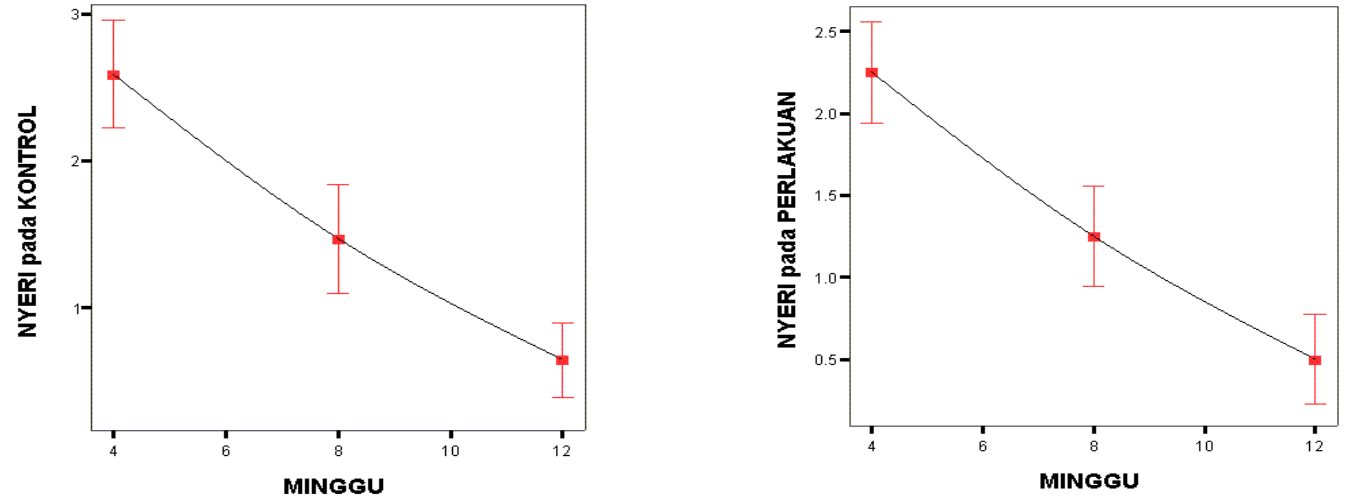

Gambar 2. Kurva perubahan variabel derajat nyeri berdasarkan minggu pengamatan

Kurva ini menunjukkan penurunan skala nyeri pada kelompok perlakuan terjadi lebih banyak pada minggu ke IV, tetapi rasa nyeri yang berkurang tidak berbeda secara bermakna pada minggu ke XII. Dapat disimpulkan bahwa pemberian gelombang ultrasonik mempercepat hilangnya nyeri.

\section{Efek pemberian gelombang ultrasonik intensitas rendah terhadap kalus}

Pada pemeriksaan ketebalan kalus pada perlakuan dan kontrol didapatkan hasil sebagai berikut (tabel 3 )

Tabel 3. Perbandingan antara perlakuan dan kontrol dari hasil pemeriksaan kalus

\begin{tabular}{|c|c|c|c|c|c|c|c|c|c|c|}
\hline & \multicolumn{3}{|c|}{ MINGGU } & \multicolumn{3}{c|}{ MINGGU } & \multicolumn{3}{c|}{ MINGGU } & JUMLAH \\
& IV & \multicolumn{3}{c|}{ VIII } & \multicolumn{3}{c|}{ XII } & SAMPEL \\
\cline { 2 - 8 } NILAI SKALA KALUS & $\mathbf{0}$ & $\mathbf{1}$ & $\mathbf{2}$ & $\mathbf{2}$ & $\mathbf{3}$ & $\mathbf{4}$ & $\mathbf{3}$ & $\mathbf{4}$ & $\mathbf{5}$ & \\
\hline PERLAKUAN & 1 & 13 & 2 & 0 & 4 & 12 & 0 & 2 & 14 & 16 \\
\hline KONTROL & 1 & 14 & 2 & 1 & 7 & 9 & 0 & 7 & 10 & 17 \\
\hline
\end{tabular}

untuk variabel kalus

\begin{tabular}{|c|c|c|c|c|}
\hline Kalus & Group & $\mathrm{N}$ & Mean Rank & $p$ value \\
\hline \multirow{2}{*}{ Minggu IV } & Kontrol & 17 & 16.85 & 0.929 \\
\cline { 2 - 4 } & Perlakuan & 16 & 17.16 & \\
\hline $\begin{array}{c}\text { Minggu } \\
\text { VIII }\end{array}$ & Kontrol & 17 & 15.12 & 0.260 \\
\cline { 2 - 4 } $\begin{array}{c}\text { Minggu } \\
\text { XII }\end{array}$ & Perlakuan & 16 & 19.00 & \\
\cline { 2 - 4 } & Kontrol & 17 & 14.71 & 0.069 \\
\hline
\end{tabular}

Data pada Tabel 4 menunjukkan bahwa pembentukan kalus pada perlakuan cenderung lebih tinggi dibandingkan dengan pada kontrol. Disamping itu, juga dapat diketahui bahwa derajat perbedaan pembentukan kalus pada minggu awal (minggu IV) lebih rendah $(p=0.929)$ dibandingkan dengan pada minggu akhir (minggu XII; $p=0.069$ ). Pada minggu XII pembentukan

Maj. Kedok. Unibraw Vol. XIX, No.2, Agustus 2003 

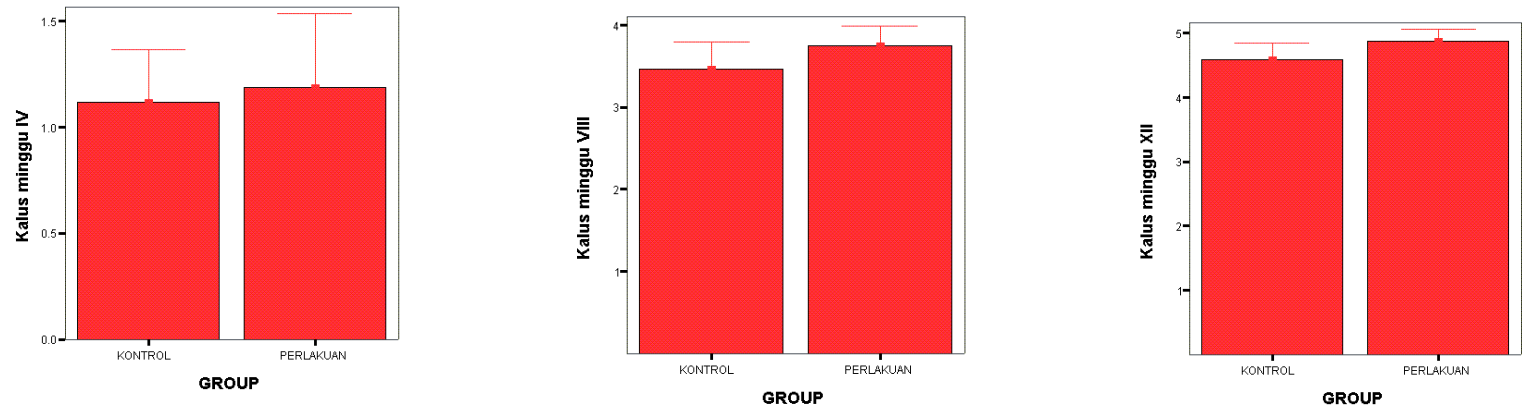

Gambar 3. Histogram variabel pembentukan kalus pada perlakuan dan Kontrol

Pembentukan kalus pada minggu ke XII lebih tebal dan berbeda secara signifikan pada kelompok perlakuan dibandingkan dengan kelompok kontrol
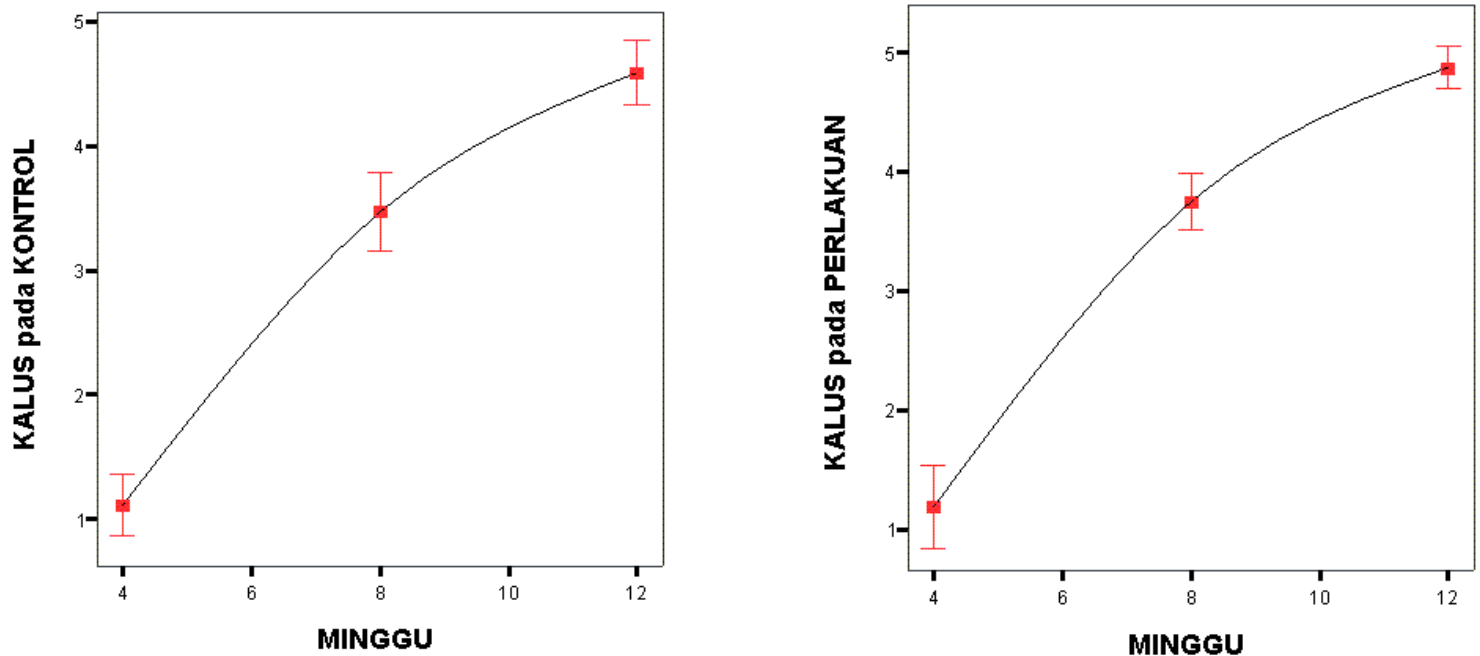

Gambar 4. Kurva perubahan pembentukan kalus berdasarkan minggu pengamatan

Pembentukan kalus lebih banyak pada kelompok perlakuan pada minggu ke XII

kalus pada perlakuan lebih tebal. Perbedaan tersebut secara

\section{Efek pemberian gelombang ultrasonik intensitas rendah terhadap sticky}

Untuk penilaian sticky tidak terdapat perbedaan antara perlakuan dan kontrol dalam 3 kali pemeriksaan.

\section{PEMBAHASAN}

Dari analisis statistik hasil penelitian dengan menggunakan Mann-Whitney test untuk mengetahui manfaat pemberian gelombang ultrasonik intensitas rendah untuk mempercepat pembentukan kalus pada fraktur tibia dengan indikator nyeri, sticky dan ketebalan kalus didapatkan:

Derajat nyeri pada perlakuan cenderung lebih rendah dibanding kontrol. Dari data ini juga dapat diartikan pada perlakuan nyeri cenderung lebih cepat menurun dibanding kontrol. Hal lain yang dapat diketahui adalah perbedaan derajat nyeri pada minggu awal lebih tinggi $(p=0,104)$ dibanding minggu akhir $(p=0,400)$. Hal ini mungkin disebabkan makin lama nyeri makin hilang, sehingga perbedaan antara perlakuan dan kontrol makin tidak nyata. visual dapat dilihat pada Gambar 3 dan 4.

Derajat ketebalan kalus yang dinilai dari hasil pemeriksaan foto rontgen, pada perlakuan cenderung lebih tinggi dibanding pada kontrol. Disamping itu juga dapat diketahui bahwa perbedaan derajat ketebalan kalus pada minggu akhir lebih tinggi dibanding minggu awal atau dengan kalimat lain makin lama makin nyata perbedaannya.

Pada pemeriksaan dengan indikator sticky antara kedua kelompok tidak terdapat perbedaan sama sekali. Mulai minggu IV sampai dengan minggu XII semua sampel sudah sticky. Pemeriksaan sticky kurang sensitif dibandingkan dengan pemeriksaan skala rasa nyeri.

Hasil pemeriksaan hilangnya nyeri dengan pembentukan kalus semestinya berjalan seiring, nyeri makin hilang mestinya kalus makin tebal. Pada hasil penelitian ini untuk penilaian pada minggu yang sama $p$ value nyeri lebih rendah. Hal ini kemungkinan terjadi karena perbedaan hasil penelitian yang dipengaruhi subyektifitas. Pemeriksaan hilangnya nyeri lebih subyektif karena dipengaruhi kondisi fisik dan psikologis pasien/sampel dan juga subyektifitas pemeriksa. Sedangkan 
pemeriksaan ketebalan kalus lebih obyektif dibandingkan pemeriksaan nyeri karena hanya dipengaruhi subyektifitas pemeriksa saja. Untuk pemeriksaan ketebalan kalus dibuat dengan alat foto rontgen yang sama dengan standard yang sama ( $\mathrm{Kv}, \mathrm{mA}$, jarak obyek dengan sumber sinar).

Sampai minggu XII untuk pemeriksaan ketebalan kalus didapatkan $p=0,069$. Dengan model regresi non linier dapat diperkirakan bahwa $p=0,05$ dapat dicapai pada minggu XIV. Pada penelitian ini hanya diamati sampai minggu XII, sedangkan pada penelitian yang dilakukan Warden et al. (2000), Heckman et al. (1994) dan Kristiansen et al. (1997) diamati sampai dengan hari ke 120 dan bahkan sampai hari ke $180(5,7,8)$. Hal yang sama sulit dilakukan disini, karena pasien/sampel yang sudah merasa sembuh tidak kontrol lagi.

Dengan menggunakan dasar hukum Wolff dan efek yang didapatkan ditentukan oleh jumlah energi yang diterima sasaran, makin banyak energi yang diterima sampai batas toleransi tertentu makin besar efek pencepatan pembentukan kalus yang terjadi (15,21). Pada penelitian ini hanya diberikan sebanyak 10 kali dengan lama pemberian 15 menit dengan selang waktu antar pemberian 3 hari. Sebagai pembanding pada penelitian yang dilakukan oleh Warden et al. (2000) dan Heckman et al. (1994) dengan memakai alat Sonic Accelerated Fracture Healing System (SAFHS) diberikan setiap hari, lama pemberian 20 menit dan diberikan sebanyak $30-50$ kali $(5,7)$. Hal ini tidak dapat dilakukan pada penelitian ini mengingat keterbatasan yang ada. Alat juga dipakai untuk fungsi pelayanan yang lain dan sampel juga sulit untuk datang setiap hari.

Untuk penilaian sticky tidak mudah. Sticky hanya dapat dinilai pada pasien/sampel yang ditatalaksana secara konservatif (bukan yang dipasang implant). Pemeriksaan bisa dilaksanakan dengan melepas gips. Tetapi ada hal lain yang perlu mendapat perhatian, gips tidak boleh terlalu sering dilepas karena akan mengganggu stabilitas yang pada akhirnya akan memperlama penyembuhan. Pada penanganan pasien dengan implant, tidak dapat digunakan indikator sticky. Tindakan operasi dengan memasang implant lebih banyak dilakukan karena akan mempercepat mobilisasi dan memperpendek masa rawat di rumah sakit. Pada pasien dengan implant rangsang gelombang ultrasonik diperkirakan masih dapat memberi manfaat untuk mempercepat pembentukan kalus, karena implant bersifat menghantarkan gelombang ultrasonik, tentunya dengan dosis dan cara pemberian yang berbeda.

Dengan melihat hasil penelitian ini dan juga perkiraan dengan model regresi non linier, pemberian gelombang ultrasonik intensitas rendah dengan dosis tersebut diatas dapat dipertimbangkan sebagai jalan alternatif untuk mempercepat pembentukan kalus.

\section{KESIMPULAN DAN SARAN KESIMPULAN}

Dari penelitian ini dapat disimpulkan bahwa pemberian gelombang ultrasonik intensitas rendah dengan lama pemberian 15 menit, sebanyak 10 kali dan selang waktu antar pemberian 3 hari pada fraktur tibia yang ditatalaksana secara konservatif (reposisi dan plaster) terbukti mampu mempercepat pembentukan kalus $(p=0,069)$.

\section{SARAN}

Dari penelitian ini ada beberapa hal yang bisa dicatat dan disarankan untuk penelitian selanjutnya adalah pada pasien dengan pemasangan fiksasi interna/eksterna, dan diusulkan menjadi pengobatan ajuvan pada penatalaksanaan fraktur.

\section{DAFTAR PUSTAKA}

1. Catatan Rekam Medis IRD RSUD Dr. Saiful Anwar Malang. 2002.

2. Rubin, C., Bolander, M., Ryaby, J.P., Hadjiargyrou, M., Current Concepts Review: The Use Of Low-Intensity Ultrasound To Accelerate The Healing Fractures. J Bone joint Surg Am. 2001: 83-A : 259-269.

3. Dradjat, R.S., Pengaruh Gelombang Ultrasonik Intensitas Rendah Terhadap Percepatan Fungsionalisasi Osteoblas, Penelitian Eksperimental Laboratoris In Vitro, Disertasi Program Doktor, Program Pasca Sarjana Universitas Airlangga, Surabaya. 2002.

4. Hankemeier, S., Grassel, S., Plenz, G., Speigel, H.U., Bruckner, P., Probst, A., Alteration Of Fracture Stability Influences Chondrogenesis, Osteogenesis And Immigration Of Macrophages. J Orthop research. 2001: 19: 531-538.

5. Warden, S.J., Bennel, K.I., McMeeken, J.M., Wark, J.D., Acceleration Of Fresh Fracture Repair Using The Sonic Accelerated Fracture Healing System (SAFHS): a review. Orthop Surg Forum. 2000: 66: 157-163.

6. Fujioka, H., Tsonuda, M., Noda, M., Matsui, N., Mizuno, K., Treatment Of Ununited Fracture Of The Hook Of Hamate By LowIntensity Pulsed Ultrasound: a case report. J Hand Surg. 2000: 25A: 77-79.

7. Heckman, J.D., Ryaby, J.P., McCabe, J., Frey, J.J., Kilcoyne, R.F., Acceleration Of Tibial Fracture-Healing By Non Invasive, LowIntensity Pulsed Ultrasound. J Bone joint Surg Am. 1994: 76: 26-34.

8. Kristiansen, T.K., Ryaby, J.P., McCabe, J., Frey, J.J., Roe, L.R., Accelerated Healing Of Distal Radial Fractures With The Use Of Specific, Low-Intensity Ultrasound. A multicenter, prospective, randomized, double-blind, placebo controlled study. J Bone Surg Am. 1997: 79: 961-973.

9. Jinghusi, S., Azuma, V., Ito, M., Harada, Y., Takagi, H., Ohta, T., Komoriya, K., Effects Of Non-Invasive Pulsed Low-Intensity Ultrasound On Rat Femoral Fracture. In proceedings of the Third World Conggress of Biomechanics. 1998: 175b.

10. Cook, S.D., Ryaby, J.P., McCabe, J., Frey, J.J., Heckman, J.D., Kristiansen, T.K., Acceleration Of Tibia And Distal Radius Fracture Healing In Patients Who Smoke. Clin Orthop. 1997: 337: 198-207.

11. Lane, J.M., Peterson, M., Ryaby, J.P., Testa, F., Ultrasound Treatment In 2126 Fractures. In proceedings of the Sixth Meeting of International Society for Fracture Repair, Strasbourg. J Orthop Trauma. 1999: 13: 313.

Maj. Kedok. Unibraw Vol. XIX, No.2, Agustus 2003 
12. Nolte, P.A., Klein-Nulend, J., Albers, G.H.R., Marti, R.K., Semeins, C.M., Geoci, S.W., Burger, E.H., Low Intensity Ultrasound Stimulates Endochondral Ossification In Vitro.

13. Parvizi, J., Purpura, J., Greenleaf, J.F., Bolander, M.E., Calcium Signaling Is Required For Ultrasound Stimulates Agreccan Synthesis By Rat Chondrocytes.

14. Mayr, E., Rutzki, M.M., Rudzki, M., Borchardt, B., Ruter, A., Does Low Intensity Ultrasound Speed Healing Of Schapoid Fracture? Handchir Mikrochir Plast Chir. 2000: 32: 115-122.

15. Hoogland, R., Ultrasound Therapy. Drukkerij Nevelland. 1994: 6-20.

16. Kokubu, T., Matsui, N., Fujioka, H., Tsunoda, M., Mizuno, K., Low-intensity Pulsed Ultrasound Exposure Increase Prostaglandine E2 Production Via The Induction Of Cyclooxigenase-2 mRNA in Mouse Osteoblast. Biochem.Biophys.Res.Comm. 1999: 256, 284287.

17. Chapman, I.V., MacNally, N.A., Tucker, S., Ultrasound Induced Changes In Rates Of Influx And Efflux Of Potassium lons In Rat Thymocytes In Vitro. Ultrasound Med Biol. 1980: $6: 47-58$.

18. Ito, M., Azuma, Y., Ohta, T., Komoriya, K., Efek Of Ultrasound and 1,25-dihydroxyvitamin D3 on Growth Factor Secretion In CoCultures Of Osteoblasts And Endothelial Cells. Ultrasound Med Biol. 2000: 26: 161-166.

19. Wu, C.C., Lewallen, D.G., Bolander, M.E., Bronk, J., Kinnick, R., Greenleaf, J.F., Exposure To Low Intensity Ultrasound Stimulates Agreccan Gen Expression By Cultured Chondrocytes. Trans Orthop Res Soc. 1996: 21: 622.

20. Kendall, J.M., Reeves, B.C., Latter, V.S., Multicentre Randomized Controlled Nadal Diamorhpine For Analgesia In Children And Teenagers With Clinical Fractures. British Med Journal. 2000: 322: 261-265.

21. Cruess, R.L., Healing of Bone, Tendon and Ligament. In: Rockwood CA, Green DP, Buckols RW, Heckman JD, editors. Fractures in adults, 2nd ed. Philadelphia;Lippincott-Raven. 1984: 147-167.

22. Darmawan, B., Hadi, S.A., Gambaran trauma muskuloskeletal di RS Cipto Mangunkusumo Jakarta tahun 2000-2001, PIT IKABI XIII, Denpasar. 2002.

23. Rasjad, Ch., Pengantar IImu Bedah Orthopedi, Bintang Lamumpatue, Ujung Pandang. 2000: 399-406.

24. Maylia, E., Nokes, L.D., The Use Of Ultrasonic In Orthopaedics - A Review. Technol Health Care. 1999: 7: 1-28.

25. Dysan, M., Therapetic Applications Of Ultrasound. In: Nyborg WL, Ziskin MC, editors.: Biological effects of ultrasound. New York: Churchill Livingstone. 1985: 121-133.

26. Wells, P.N.T., Surgical Applications Of Ultrasound. In: Nyborg WL, Ziskin MC, editors. Biological effects of ultrasound. New York: Churchill Livingstone. 1985: 157-167.

27. Duarte, L.R., The Stimulation Of Bone Growth By Ultrasound. Arch Orthop Trauma Surg. 1983: 101: 153-159.

28. Delmas, P.D., Biochemical Markers Of Bone Turnover. J Bone Miner Res 1993: 8(suppl 2): 549-555.

29. Basset, C.A.L., Mitchell, S.N., Gaston, S.R., Treatment Of Un-United Tibial Diaphyseal Fractures With Pulsing Electromagnetic Fields. J Bone Joint Surg (Am). 1989: 63A : 511.

30. Bowes, D.N., Hohl, M., Tibial / Condyler Fractures, Evaluation And Outcome. Clin Orthop. 1988: 171: 104.

31. Melzack, R., The Perception Of Pain. Sci Am. 1978: 204: 41.

32. Rawool, D., Goldberg, B., Forsberg, F., Winder, A., Talish, R., Hume, E., Power Doppler Assessment Of Vascular Changes During Fracture Treatment With Low Intensity Ultrasound. Trans radiol soc North Am. 1998: 83: 1185.

33. -------.Fracture Healing, from http://www.orthoteers.co.uk/Nrujp ij33lm/orthobonefracheal.htm

34. Tjokroprawiro, A., Pudjirahardjo, W.J., Taat, Putra, S., Pedoman Penelitian Kedokteran, Airlangga University Press, Surabaya. 1996: 39-67. 
Hal.

\title{
PRODUKSI IgA \& IgG MUKOSAL DAN SISTEMIK SETELAH IMUNISASI PER ORAL DENGAN PROTEIN Adh036 SALMONELLA TYPHI PADA MENCIT BALB/C
}

\section{(THE PRODUCTION OF MUCOSAL AND SYSTEMIC IgA AND IgG AFTER ORAL IMMUNIZATION WITH AdhO36 PROTEIN SALMONELLA TYPHI ON BALB/C MICE)}

\author{
Sanarto Santoso \\ Laboratorium Mikrobiologi Fakultas Kedokteran Universitas Brawijaya
}

\begin{abstract}
An experiment has been conducted to determine the production of mucosal and systemic IgA and IgG after oral immunization with AdhO36 protein Salmonella typhi using CTB as adjuvant. The results of ELISA Test, shows that AdhO36 protein Salmonella typhi were highly significantly $(p=0.001)$ able to induce the production of $S-\lg A$ (secretory $\lg A)$, as compared to control and CTB treatment. The analysis of variance results show that the effect of AdhO36 protein to the IgA content in serum is high significantly different to IgA content in mucus ( $p=0.001)$. This finding is relevant to the previous experiments that the oral administration of AdhO36 protein can inhibit the in vivo adhessive process of Salmonella typhi at enterocytes of Balb/c mice. Therefore, it can be concluded that AdhO36 protein Salmonella typhi is a potential mucosal immunogen which can induce mucosal immune response as the results of the formation of protective S-IgA, which in turn, can inhibit the adhesive process as the initial stage of infection process at enterocytes of Balb/c mice. Apart from S-IgA, in this experiment AdhO36 protein Salmonella typhi can also induce IgG serum. The analysis of variance results show that the effect of AdhO36 protein to the $\mathrm{IgG}$ content in serum is high significantly different to $\lg \mathrm{G}$ content in mucus ( $p=0.001$ ). It can then be concluded that the oral administration of AdhO36 protein as an immunogen, is not only able to stimulate the mucosal humoral immune response, but can also stimulate the systemic humoral immune response on Balb/c mice.
\end{abstract}

Key words : S-IgA, IgG, AdhO36 protein, Salmonella typhi

\section{ABSTRAK}

Telah dilakukan penelitian untuk mengetahui produksi IgA dan IgG mukosal dan sistemik setelah imunisasi per oral protein AdhO36 Salmonella typhi dengan ajuvan CTB pada mencit Balb/c. Hasil dari penelitian ini dengan menggunakan uji ELISA membuktikan bahwa protein AdhO36 Salmonella typhi mampu menginduksi S-IgA(secretory IgA) yang sangat bermakna ( $p=0,001)$ bila dibandingkan dengan kontrol dan perlakuan CTB. Hasil Anova pengaruh perlakuan terhadap kadar IgA dalam serum dan mukus untuk protein Adh036 menunjukkan bahwa rerata kadar IgA dalam mukus berbeda sangat bermakna dengan rerata kadar IgA dalam serum $(p=0,001)$. Dari penelitian terdahulu telah dapat dibuktikan bahwa protein AdhO36 pada pemberian per oral dapat menghambat proses adhesi in vivo Salmonella typhi pada enterosit mencit Balb/c. Dengan demikian dapat disimpulkan bahwa protein Adh036 Salmonella typhi merupakan imunogen mukosal poten yang mampu membangkitkan respons imun mukosal dengan terbentuknya S-IgA protektif yang dapat menghambat proses adhesi sebagai tahap awal proses infeksi, pada enterosit mencit Balb/c. Selain S-IgA, pada penelitian ini protein AdhO36 Salmonella typhi dapat juga menginduksi IgG serum. Hasil Anova pengaruh perlakuan terhadap kadar IgG dalam serum dan mukus untuk protein AdhO36 menunjukkan bahwa rerata kadar IgG dalam serum berbeda sangat bermakna dengan rerata kadar Ig $G$ dalam mukus $(p=0,001)$. Dengan demikian protein AdhO36 sebagai imunogen yang diberikan per oral tidak hanya mampu merangsang respons imun humoral mukosal, namun dapat juga merangsang respons imun humoral sistemik pada mencit Balb/c.

Kata kunci : S-IgA, IgG, protein Adh036 Salmonella typhi

\section{PENDAHULUAN}

Demam tifoid sebagai penyakit sistemik yang disebabkan oleh Salmonella typhi sampai saat ini masih merupakan problem kesehatan, utamanya di negara-negara yang sedang berkembang termasuk Indonesia. Hal ini disebabkan oleh karena berbagai faktor, salah satunya ada vaksin yang benar-benar efektif (1). Pada umumnya penderita yang berhasil mengatasi demam tifoid akan mendapatkan kekebalan terhadap infeksi ulangan; meskipun insiden terkena kekambuhan bisa terjadi sekitar $2-3 \%$ bila seseorang terpapar kembali dengan inokulum bakteri yang sangat tinggi atau mendapatkan terapi antibiotika pada awal penyakit (2).

Kontak pertama antara Salmonella spp. dengan sistem imun hospes terjadi pada level mukosa usus, kemungkinan hal ini terjadi melalui intervensi langsung akibat proses adhesi, invasi, dan multiplikasi di dalam mukosa (3). Secretory IgA (S$\operatorname{lgA}$ ) antibodies dilaporkan protektif pada mencit yang secara oral diinfeksi dengan Salmonella typhimurium virulen (4).

Beberapa bukti menunjukkan bahwa infeksi Salmonella typhi pada manusia menginduksi respons imun humoral dan seluler (5). Antibodi yang beredar dalam sirkulasi ditujukan

Maj. Kedok. Unibraw Vol. XIX, No.2, Agustus 2003 
kepada LPS dan flagella. Sedangkan respons imun terhadap ViPS (kapsul polisakarida) sangat rendah kecuali pada chronic typhoid carriers (6). Disamping itu didapatkan juga respons serum antibodi yang bermakna terhadap antigen protein Salmonella typhi yang termasuk specific outer membrane protein (7).

Materi yang menjadi subyek penelitian adalah protein adhesin OMP (outer membrane protein) bakteri Salmonella typhi. Dari penelitian pendahuluan diketahui memiliki berat molekul $36 \mathrm{kD}$, protein adhesin OMP $36 \mathrm{kD}$ ini kemudian diberi nama protein AdhO36.

Molekul adhesin yang berpotensi imunogenik dapat digunakan sebagai komponen vaksin mukosal untuk tujuan mencegah terjadinya penyakit infeksi. Vaksin mukosal berupa molekul adhesin ini akan memberikan serangan ganda pada bakteri, yaitu melalui antibodi yang akan menghambat perlekatan dan memberi tanda pada bakteri untuk dihancurkan oleh sistem imun (8). Hambatan pada proses perlekatan bakteri Salmonella typhi pada sel epitel usus dapat dimanfaatkan di dalam usaha pencegahan penyakit demam tifoid yang saat ini masih merupakan masalah penyakit infeksi yang harus diatasi. Dari penelitian terdahulu telah terbukti bahwa imunisasi per oral protein Adh036 mampu menghambat proses adhesi in vivo Salmonella typhi pada enterosit mencit Balb/c (9).

Keuntungan yang penting dari pengembangan vaksin mukosal adalah kecenderungan untuk menginduksi baik respons imun mukosal maupun sistemik. Karena pertahanan humoral spesifik diperankan oleh antibodi serum dan antibodi sekresi terutama IgA, maka peningkatan dan pengembangan vaksin ke depan dibutuhkan vaksin yang mampu menginduksi keduanya baik respons imun mukosal maupun sistemik. Kemampuan vaksin seperti itulah yang saat ini menjadi pusat perhatian pengembang vaksin (10).

Tujuan dari penelitian ini adalah membuktikan bahwa protein adhesin yang berasal dari OMP yang diberi nama protein Adh036 Salmonella typhi tersebut apabila diberikan per oral bersifat imunogenik dan mampu menginduksi respons imun humoral baik mukosal maupun sistemik pada hewan coba mencit Balb/c.

\section{MATERI DAN METODA}

\section{Bakteri:}

Salmonella typhi diperoleh dari spesimen klinis penderita demam tifoid di R.S.Dr.Saiful Anwar Malang. Kultur bakteri menggunakan prosedur yang biasa dilakukan di laboratorium Mikrobiologi FK Unibraw dan identifikasi bakteri dilakukan dengan Microbact System.

\section{Bahan dan Reagensia:}

MacConkey agar, BSA, TCG agar, BHI broth, Trichloroacetic acid (TCA), Phosphat Buffer Saline (PBS), EGTA, dithiothreitol, bahan \& reagens untuk elektroforesis SDS-PAGE, Sephacryl HR-100, detergent untuk OMP: Chaps [3-\{(3Cholamydopropyll)-dimethyl-ammonio\}-1-prophanesulfonate] (Sigma Ultra), Ajuvan: CTB, Microbact System, bahan pewarnaan Gram.

\section{Hewan Coba:}

Mencit betina galur Balb/c, berat sekitar 25 gram, umur sekitar 8 minggu, yang diperoleh dari Pusvetma-Wonocolo, Surabaya.

Alat:

Sentrifus biasa, sentrifus dingin, alat pemotong pili omnimixer, inkubator, timbangan elektrik, shaker incubator, alat elektroforesis SDS-PAGE, kolom untuk kromatografi gel.

\section{Perbanyakan bakteri:}

Setelah dilakukan identifikasi Salmonella typhi, bakteri isolat diperbanyak pada medium MacConkey diinkubasikan pada suhu $37^{\circ} \mathrm{C}$ selama $18-24$ jam. Biakan dari medium MacConkey ini kemudian dipindahkan kedalam medium biphasic yang terdiri atas medium cair BHI dan medium agar miring TCG, diinkubasikan pada suhu $37^{\circ} \mathrm{C}$ selama 24 jam $(11,12)$.

\section{Pemisahan bagian sel dari fimbriae:}

Biakan cair dari medium biphasic dipindahkan kedalam tabung sentrifus $100 \mathrm{cc}$, ditambahkan TCA sehingga konsentrasinya $3 \%$, kemudian diputar pada sentrifus dingin $4^{\circ} \mathrm{C}$ 6000 rpm selama 15 menit. Endapan disuspensi dengan PBS pH 7,4 secukupnya, kemudian dilakukan pemotongan fimbriae menggunakan alat omnimixer pada suhu $4^{\circ} \mathrm{C}(12,13)$. Sampel kemudian diputar dalam sentrifus dingin $4^{\circ} \mathrm{C} 12.000 \mathrm{rpm}$ selama 15 menit. Filtrat dipisahkan (mengandung fraksi fimbriae) dan endapan disuspensi dengan PBS pH 7,4 secukupnya, kemudian dilakukan pemotongan fimbriae lagi. Proses ini diulangi sampai kira-kira 7 kali dan dihentikan setelah terlihat perbedaan pola protein yang jelas antara fraksi fimbriae dengan fraksi sel (dilakukan elektroforesis). Dari prosedur ini, diperoleh endapan yang merupakan bagian sel bakteri dan digunakan untuk fraksinasi OMP

\section{Fraksinasi OMP:}

Bagian sel dari prosedur diatas, disuspensi dengan PBS pH 7,4 secukupnya, kemudian ditambahkan Chaps (3-\{(3Cholamidopropyl)-dimethyl-ammonio\}-1-propanesulfonate).

sehingga diperoleh kadar $0,5 \%$ (b/v). Dikocok menggunakan vortex selama 5 menit, kemudian diputar pada sentrifus dingin $4^{\circ} \mathrm{C} 12.000 \mathrm{rpm}$ selama 15 menit. Filtrat diambil, dilakukan dialisis menggunakan PBS pH 7.4 untuk menghilangkan Chaps. Kemudian dialisat diendapkan dengan ammonium sulfat $35 \%$, disentrifus pada $4^{\circ} \mathrm{C} 6000 \mathrm{rpm}$ selama 15 menit. Filtrat dibuang, endapan disuspensi dengan PBS secukupnya dan dilakukan dialisis kembali. Dialisat disimpan sebagai fraksi OMP (14).

\section{Preparasi antigen :}

Yang disebut antigen dalam hal ini adalah protein Adhesin-036 (Adh036). Untuk pemurnian protein antigen dipakai metode khromatografi gel menggunakan Sephacryl HR-100. Sebagai washing solution dipakai TEA dan sebagai eluen adalah TEAN. Hasil eluat khromatografi dielektroforesis SDS-PAGE menurut metode Laemli (1970) (15). Kemudian pita protein pada posisi berat molekul sekitar $36 \mathrm{kDa}$ dipotong dan dikumpulkan, selanjutnya dilakukan elektroelusi sehingga diperoleh endapan kering protein yang dimaksud. 
Hal.

\section{Pemeriksaan Produksi Antibodi (Metoda ELISA)}

Parameter yang diamati pada pemeriksaan antibodi ini adalah kadar $\lg G$ dan IgA di dalam serum dan di dalam mukus.

Dalam uji ini menggunakan 3 kelompok, yaitu: 1) perlakuan kontrol, mencit tidak diberi imunisasi; 2) perlakuan CTB, mencit diimunisasi dengan CTB $7 \mu \mathrm{g} / 0.3 \mathrm{ml}$ PBS per mencit; 3) perlakuan protein adhesin-O36 (AdhO36), mencit diimunisasi dengan CTB + protein Adh036 $250 \mu \mathrm{g} / 0.3 \mathrm{ml} \mathrm{PBS}$. Sebelum diberi perlakuan, masing-masing mencit diberi larutan natrium bikarbonat $0,2 \mathrm{M}$ sebanyak $0,3 \mathrm{ml}$. Semua perlakuan ini diberikan per oral. Imunisasi diberikan 4 kali selang satu minggu, dan pada akhir minggu ke 4 mencit dimatikan, diambil serum dan mukusnya. Sampel serum dan sampel mukus dikumpulkan dari setiap 2 mencit sebagai pooled serum dan pooled mucus. Preparasi sampel serum dilakukan seperti pada Uji Imunogenisitas, sedangkan preparasi mukus adalah sebagai berikut: potongan usus dicuci dengan PBS dingin yang mengandung protease inhibitor $(25 \mu \mathrm{g} / \mathrm{ml}$ inhibitor cocktail) dan 1,0 mM EDTA, kemudian usus dibuka sehingga terlihat bagian mukosa usus halus. Lapisan mukus diambil dengan cara scraping secara longitudinal menggunakan spatel dan ditampung di dalam tabung yang berisi PBS steril dan protease inhibitor. Suspensi dikocok, kemudian disentrifus $12,000 \mathrm{rpm}$ pada $4^{\circ} \mathrm{C}$ selama 10 menit. Supernatan diambil, dilakukan pemurnian seperti pada pemurnian serum dan digunakan sebagai sampel mukus untuk pemeriksaan S-IgA (secretory $\lg A$ ) dan IgG dengan metode ELISA (16).

\section{HASIL}

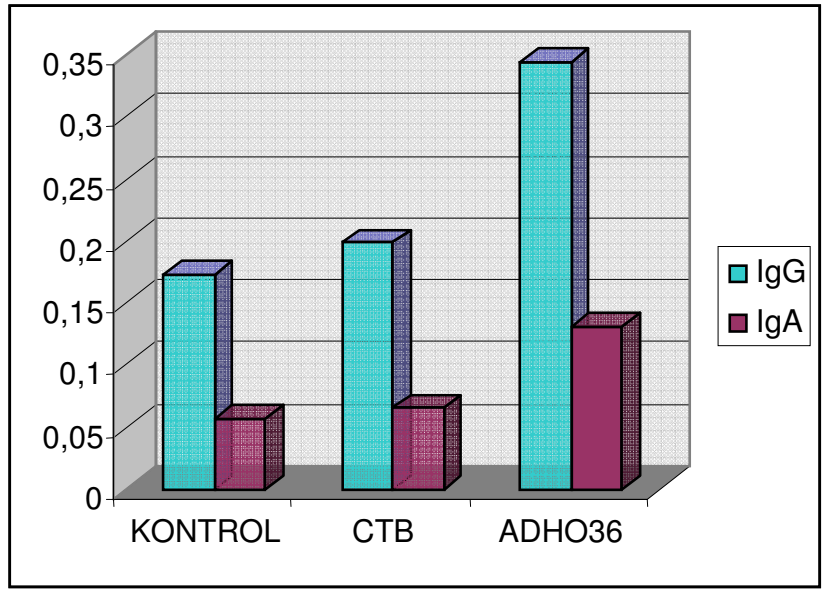

Gambar 1. Hasil rerata ELISA serum pasca imunisasi per oral dengan Protein Adh036

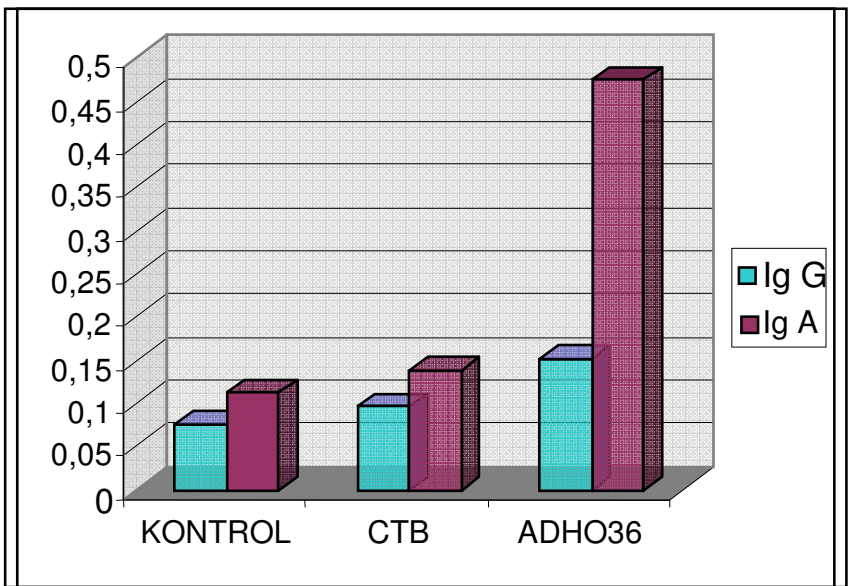

\section{Gambar 2. Hasil rerata ELISA mukus pasca imunisasi per oral dengan Protein AdhO36}

Gambar 1 dan Gambar 2 masing-masing menunjukkan rerata hasil Uji ELISA tentang kadar IgG dan IgA dalam serum dan mukus terhadap protein Adh036 setelah perlakuan, dengan pengulangan 4 kali. Tampak bahwa protein AdhO36 mampu menginduksi IgG serum dan $\lg A$ mukosal (S-lgA) dalam konsentrasi yang tinggi.

Hasil Anova pengaruh perlakuan terhadap kadar lgG dalam serum dan mukus untuk protein AdhO36 menunjukkan bahwa rerata kadar IgG dalam serum berbeda bermakna dengan rerata kadar Ig $G$ dalam mukus $(p=0.001)$. Pengaruh perlakuan terhadap kadar lgG dalam mukus tidak berbeda bermakna $(p=0.059)$, tetapi berbeda bermakna pada kadar lg $G$ dalam serum $(\mathrm{p}=0.012)$.

Hasil Anova pengaruh perlakuan terhadap kadar IgA dalam serum dan mukus untuk protein AdhO36 menunjukkan bahwa rerata kadar IgA dalam mukus berbeda bermakna dengan rerata kadar IgA dalam serum $(p=0.001)$. Pengaruh perlakuan terhadap kadar IgA dalam serum tidak berbeda bermakna $(p=0.447)$, tetapi pengaruh perlakuan berbeda bermakna pada kadar IgA dalam mukus $(p=0.001)$. Hasil Tukey's test disajikan seperti pada tabel 1 dan 2

Tabel 1. Hasil Tukey's test Pengaruh Perlakuan terhadap Kadar IgG Serum untuk Protein Adh036

\begin{tabular}{|c|c|}
\hline Perlakuan & Rerata \\
\hline \hline Kontrol & $0.173 \mathrm{a}$ \\
\hline CTB & $0.199 \mathrm{a}$ \\
\hline AdhO36 & $0.346 \mathrm{~b}$ \\
\hline
\end{tabular}

Keterangan:

Nilai rerata yang didampingi huruf yang sama berarti tidak berbeda bermakna dengan $p=0.05$ dan nilai $\mathrm{HSD}=0.163$ 
Tabel 2. Hasil Tukey's test Pengaruh Perlakuan terhadap Kadar IgA dalam Mukus untuk Protein Adh036

\begin{tabular}{|c|c|}
\hline Perlakuan & Rerata \\
\hline \hline Kontrol & $0.112 \mathrm{a}$ \\
\hline CTB & $0.135 \mathrm{a}$ \\
\hline AdhO36 & $0.475 \mathrm{~b}$ \\
\hline
\end{tabular}

Keterangan:

Nilai rerata yang didampingi huruf yang sama berarti tidak berbeda bermakna dengan $p=0.05$ dan nilai $B N J=0.168$

\section{PEMBAHASAN}

Guna menghindari oral tolerance dimana sistem imun mukosal menjadi tidak responsif terhadap imunogen oral, maka protein atau imunogen tersebut harus dikonyugasikan dengan ajuvan tersebut misalnya cholera toxin (CT) atau cholera toxin subunit-B (CTB) dan LT dari E.coli $(17,18)$. Sebenarnya banyak bahan lain yang dapat digunakan sebagai ajuvan mukosal dari penelitian-penelitian selanjutnya, antara lain yang berasal dari bagian bakteri ialah LPS, yang berasal dari toxin bakteri selain CT dan LT Pertussigen, Clostridium difficile toxins, Shiga toxin dan Staphylococcal enterotoxins, tetapi kelihatannya semua memberikan efek toksik. Bahan sintetis yang dapat digunakan sebagai ajuvan mukosal adalah Quil $A$, suatu komponen dari saponin, bahan deterjen yang berasal dari tumbuhan Quillaja saponaria Molina. Penggunaan Quil A sebagai ajuvan terbatas karena efek toksiknya, namun telah dapat diidentifikasi fraksi QuilA yang nontoksik dan sekarang digunakan sebagai salah satu komponen dari ISCOM (Immunostimulating Complexes). Selain itu, ada juga sitokin yang memiliki aktivitas ajuvan, di antaranya adalah IL-12. Pada pemberian oral, IL-12 memberikan respons yang kurang-lebih sama dengan pemberian parenteral, namun respons IgA mukosal tampaknya tidak terpengaruh. Kelihatannya, IL-12 bila diberikan peroral dengan antigen akan menimbulkan respons Th1 yang akan memberikan proteksi terhadap patogen intraseluler. Sedangkan IL-13 bila diberikan dalam vaksin mukosal tampaknya dapat meningkatkan respons Th2, tetapi hipotesis ini perlu diuji lebih lanjut (18).

Pada percobaan ini digunakan CTB sebagai ajuvan sekaligus sebagai protein carrier untuk protein Adh036. Digunakannya CTB sebagai ajuvan pada percobaan ini antara lain karena (1) CTB merupakan salah satu ajuvan yang poten yang sering digunakan, (2) CTB bisa diterima dengan baik oleh traktus gastro intestinalis, dan stabil pada suasana asam, (3) CTB bertanggung jawab pada pengikatan dengan reseptor $\mathrm{G}_{\mathrm{M} 1}$ yang terdapat pada semua sel berinti termasuk epitel usus, dan (4) CTB tidak toksik, terutama apabila vaksin ini akan dicobakan kepada manusia (19).

Dari hasil Anova pengaruh perlakuan terhadap kadar IgG dalam serum dan mukus untuk protein AdhO36, menunjukkan bahwa rerata kadar IgG di dalam serum berbeda sangat bermakna dengan rerata kadar IgG mukus $(p=0.001)$. Pengaruh perlakuan terhadap kadar IgG dalam mukus tidak berbeda bermakna $(p=0.059)$, sedangkan pengaruh perlakuan terhadap kadar IgG dalam serum berbeda bermakna $(p=0.012)$. Dari hasil Tukey's test tentang pengaruh perlakuan terhadap kadar
IgG serum untuk protein AdhO36 (Tabel 1) menunjukkan bahwa terdapat perbedaan yang sangat bermakna antara perlakuan kontrol dan CTB dengan perlakuan AdhO36. Hal ini menunjukkan bahwa kadar IgG dalam serum lebih tinggi dari kadar IgG dalam mukus terhadap protein AdhO36 sebagai antigen. Hal ini sesuai dengan teori yang ada tentang estimasi produksi IgG pada manusia dewasa sehat, dimana kadar IgG dalam sirkulasi (sekitar $2100 \mathrm{mg}$ ) lebih tinggi dari pada kadar IgG dalam usus kecil (sekitar $590 \mathrm{mg}$ ) per hari (20). Dengan demikian maka kelihatannya pada percobaan ini, IgG sebagai respons imun mukosal terhadap protein AdhO36 sedikit sekali yang disekresikan ke dalam lumen usus.

Pada Anova pengaruh perlakuan terhadap kadar IgA di serum dan mukus untuk protein AdhO36, menunjukkan bahwa rerata kadar IgA dalam serum berbeda sangat bermakna dengan rerata kadar IgA dalam mukus $(p=0.001)$. Pengaruh perlakuan terhadap kadar IgA di dalam serum tidak berbeda bermakna $(p=$ 0.447), sedangkan pengaruh perlakuan terhadap kadar $\lg A$ dalam mukus berbeda sangat bermakna $(p=0.001)$. Dari hasil Tukey's test tentang pengaruh perlakuan terhadap kadar IgA mukus untuk protein AdhO36 (Tabel 2) menunjukkan bahwa terdapat perbedaan yang sangat bermakna antara perlakuan kontrol dan CTB dengan perlakuan AdhO36. Dengan demikian menunjukkan bahwa kadar IgA yang terbentuk dalam serum sangat sedikit, sebaliknya yang disekresikan dalam mukus sangat banyak. Hal ini telah jelas diketahui bahwa IgA pada sekresi mukosal berada dalam konsentrasi yang lebih tinggi dibandingkan dengan imunoglobulin yang lain; bisa mencapai lebih dari 3 gr per hari pada manusia dewasa sehat (21).

Melihat pengaruh perlakuan terhadap kadar IgG dalam serum yang lebih besar dari pada kadar lgG dalam mukus untuk AdhO36 serta melihat pengaruh perlakuan terhadap kadar S-IgA (IgA dalam mukus) yang lebih besar dari pada kadar IgA dalam serum untuk AdhO36, maka hal ini sesuai dengan respons imun humoral normal. Kadar IgG dalam serum memang lebih tinggi dibandingkan dengan IgG dalam sekresi usus, demikian pula kadar IgA dalam sekresi usus memang lebih tinggi dari pada IgA dalam serum (21). Dengan demikian maka protein AdhO36 dengan dosis $250 \mu \mathrm{g}$ dan $7 \mu \mathrm{g}$ CTB (perlakuan AdhO36) telah menunjukkan potensinya untuk menginduksi IgG dalam serum dan IgA dalam mukus yang tinggi. Pada penelitian yang lain yang menggunakan tetanus toxoid sebagai antigen sebanyak $250 \mu \mathrm{g}$ dan $10 \mu \mathrm{g}$ CT yang diberikan secara per oral $3 \times$ dengan interval 1 minggu dapat menginduksi IgA di tinja dan IgG di dalam serum yang tinggi (22). Juga penelitian yang menggunakan $200 \mu \mathrm{g}$ protein solubel HEL (hen egg lysozyme) dan $5-10 \mu \mathrm{g}$ CT yang diberikan $2 \times$ dengan interval 3 minggu dapat menginduksi respons $\lg G$, IgA dan IgE intestinal (23).

Gabungan protein AdhO36 dan CTB yang diberikan secara oral pada mencit, akan masuk melalui sel $M$ untuk ditangkap oleh APC. APC melalui jalur MHC-II akan menyajikan peptida kepada sel $\mathrm{T} \mathrm{CD4}^{+}$kemudian mengaktifkannya untuk selanjutnya berinteraksi dengan sel $\mathrm{B} / \mathrm{lgM}$ dan menginduksi class-switching menjadi sel B/lgA dibawah pengaruh TGF- $\beta$ dan IL-5; yang semuanya terjadi dalam Peyer's patch. Sel B/lgA akan masuk ke lamina propria melalui mesenteric lymph node (MLN) untuk menjadi sel plasma dibawah pengaruh CD40L, IL-5 dan IL6 , yang akan mensintesa polymeric/dimeric IgA. Dimeric IgA 
Hal.

berikatan dengan poly lg receptor (secretory component=SC) pada membran basolateral sel epitel mukosa. Kompleks ini ditransportasikan secara aktif melintas sel epitel mukosa dan dilepaskan melalui pemecahan proteolitik ke dalam lumen sebagai S- $\lg A(17,24,25)$.

Sistem yang baik ini memberikan immune exclusion pada permukaan mukosa, yaitu mencegah masuknya patogen baru melalui pertahanan mukosa. Di samping itu, transitosis memberikan immune elimination yang terdiri atas transpor aktif ikatan IgA-patogen baik dari stroma maupun epitel menuju lumen digestif, serta membuat patogen menjadi inaktif sebelum dilepaskan (26). Alasan yang memungkinkan, mengapa IgA diproduksi lebih banyak dalam sistem imun mukosal dibandingkan jaringan yang lain, karena isotype switching ke IgA terjadi paling efisien dalam jaringan limfoid mukosal; di samping itu sel Th2 yang memproduksi IL-5 lebih banyak dalam mukosa dibandingkan dalam jaringan limfoid yang lain. Sel B yang memproduksi IgA juga mempunyai kecenderungan untuk homing ke jaringan mukosal (24).

Adanya IgG dalam serum menunjukkan bahwa protein Adh036 sebagai antigen yang diberikan per oral tidak hanya mampu merangsang respons imun mukosal, namun juga mampu merangsang respons imun humoral secara sistemik. Hal ini terjadi karena kemungkinan ada sebagian sel APC mukosal yang telah menangkap protein Adh036+CTB langsung masuk ke dalam peredaran darah dan menginduksi respons imun sistemik sehingga terbentuk IgG serum. Dengan demikian, apabila setelah vaksinasi oral, masih ada Salmonella typhi yang berhasil lolos dari S-IgA, dan masuk peredaran darah maka akan berhadapan dengan IgG serum. Tampaknya protein AdhO36 ini dapat diandalkan sebagai kandidat vaksin oral yang bisa memberikan proteksi baik mukosal maupun sistemik, namun hal ini perlu penelitian lebih lanjut, khususnya mengenai protektivitas respons imun sistemik.

Mengenai respons serum antibodi ini telah dipelajari secara ekstensif dengan vaksin Ty21a yang sekarang telah dikemas dalam bentuk kapsul enteric coated. Penggunaan vaksin oral Ty21a ini menunjukkan kenaikan titer antibodi O IgG di dalam serum orang yang telah diberi vaksinasi. Kenaikan titer antibodi O IgG tergantung dosis vaksin yang diberikan, satu kali, dua kali atau tiga kali dalam satu minggu. Meskipun serum antibodi $\mathrm{O}$ bukan satu-satunya mekanisme pertahanan yang diberikan oleh galur yang sudah dilemahkan ini, namun jelas berkaitan erat dengan proteksi terhadap infeksi Salmonella typhi (27).

Pada penelitian terdahulu tentang Uji Hambat Adhesi In vivo, imunisasi per oral protein AdhO36 + CTB telah memberikan hasil yang sangat bermakna. Hal ini ditunjukkan dengan pertumbuhan koloni yang tidak berarti pada medium BSA (bismuth sulfite agar), yang merupakan gambaran hambatan adhesi yang sangat bermakna pada enterosit mencit Balb/c (9). Sedangkan pada penelitian ini telah dapat dibuktikan bahwa protein AdhO36 mampu menginduksi S-IgA yang sangat bermakna. Hal ini menunjukkan bahwa protein AdhO36 merupakan imunogen mukosal poten yang mampu membangkitkan respons imun mukosal dengan terbentuknya SIgA protektif yang dapat menghambat proses adhesi sebagai tahap awal proses infeksi, pada enterosit mencit Balb/c.

\section{KESIMPULAN}

Dari hasil penelitian dan pembahasan tersebut diatas dapat disimpulkan bahwa :

1. Protein AdhO36 Salmonella typhi adalah imunogen mukosal yang mampu menginduksi respons imun mukosal protektif, yaitu dengan membentuk secretory- $\lg A(\mathrm{~S}-\lg \mathrm{A})$ yang sangat bermakna untuk menghambat atau memproteksi proses adhesi dan kolonisasi Salmonella typhi pada enterosit mencit Balb/c.

2. Protein Adh036 Salmonella typhi apabila diberikan per oral pada mencit Balb/c juga mampu menginduksi respons imun humoral sistemik dengan membentuk IgG serum.

\section{SARAN}

1. Perlu dilakukan penelitian lanjutan tentang generalisasi Salmonella typhi atas kepemilikannya terhadap protein Adh036. Penelitian dapat dilakukan secara langsung terhadap galur Salmonella typhi yang ada, maupun secara tidak langsung berdasarkan kesesuaian antibodi yang terbentuk pada penderita-penderita demam tifoid terhadap protein AdhO36.

2. Telah terbukti bahwa protein Adh036 Salmonella typhi adalah imunogen mukosal yang poten pada mencit Balb/c. Selanjutnya perlu dipikirkan dan diteliti lebih lanjut kemungkinan protein tersebut diuji cobakan kepada manusia.

\section{DAFTAR KEPUSTAKAAN}

1. Pang, T., Koh, C.L., Puthucheary, S.D., Typhoid Fever: Strategies for the 90's. Singapore: World Scientific. 1992.

2. Murphy, J.R., Grez, L., Immunogenicity of Salmonella typhi Ty21a vaccine for young children. Infect Immun. 1991: 59: 4291-4293.

3. Nataro, J.P., and Levine, M.M., Enteric Bacterial Vaccine, in: Ogra, P.L., Mestecky, J., Lamm, M.E., Strober, W., Bienenstock, J., McGhee, J.R., Mucosal Immunology 2nd ed, Academic Press. 1999: 851 - 865.

4. Salyers, A.A., and Whitt, D.D., Bacterial Pathogenesis: a molecular approach. Washington DC: American Society for Microbiology Press. 1994: 30-41, 229-241.

5. Todar, K., Bacteriology 330 Lecture Topics: Colonization and Invasion. University of Wisconsin Department of Bacteriology. 1997.

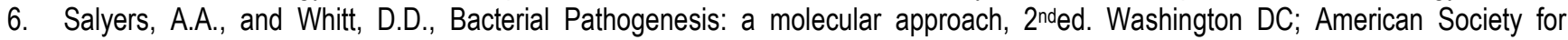
Microbiology Press. 2002: 93-94, 115-126

7. Henahan, S., E.coli vaccine; Science Update. 1997.

8. Michalek, Suzanne, M., Childers, Noel, K., Dertzbaugh, Mark, T., Vaccination Strategies for Mucosal Pathogens, in Virulence Mechanisms of Bacterial Pathogens, 2nd ed., American Society for Microbiology, Washington,D.C. 1995: 269-301.

Maj. Kedok. Unibraw Vol. XIX, No.2, Agustus 2003 
9. Santoso, S., Protektivitas in vivo protein AdhO36 Salmonella typhi isolat Malang pada mencit Balb/c, Majalah Kedokteran Universitas Brawijaya Malang. 2002: 8(3): 51-59

10. McGhee, J.R., Lamm, M.E., Strober, W., Mucosal Immune Responses : An Overview in Ogra, P.L., Mestecky, J., Lamm, M.E., Strober, W., Bienenstock, J., McGhee, J.R., Mucosal Immunology $2^{\text {nd }}$ ed, Academic Press. 1999: 485 - 506.

11. Finegold, S.M., Barron, E.J., Bailey and Scott's Diagnostic Microbiology, $7^{\text {th }}$ ed. CV Mosby Company, USA. 1986: 682, 862, 863, 879.

12. Ehara, M., Ishibashi, M., Ichinose, Y., Iwanaga, M., Shimotori, S., Naito, T., Purification and partial characterization of fimbriae of Vibrio cholerae 0-1, Vaccine. 1986: 5: 283-286.

13. Sumarno, Karakterisasi Molekuler Protein Adesi Vibrio cholerae 01 M094V dan Protein Reseptornya pada Sel Epitel Usus Halus Tikus Putih (Wistar), Studi Patogenesis Vibrio cholerae 01 M094V. Disertasi Program Pasca Sarjana Universitas Airlangga Surabaya. 2000.

14. Dhaenens, L., Szczebara, F., Husson, M.O., Identification, Characterization and Immunogenicity of Lactoferrin-Binding Protein from Helicobacter pylori, Infect Immun. 1997: 65 (5): 514-518.

15. Laemli, U.K., Cleavage of Structural Protein during the Assembly of the Head of Bacteriophage T4, Nature. 1970: 227: 680-686.

16. Hernandez, A.M., Gavilanes-Parra, S., Chavez-Berrocal, M., Molina-Lopez, J., Cravioto, A., Binding of Diarrheagenic Escherichia coli to 32 to 33 Kilodalton Human Intestinal Brush Border Proteins. Infect Immun. 1997: 65: 4494-4501.

17. Strober, W., and Fuss, I.J., The Mucosal Immune System in: Stites DP, Terr Al, Parslow TG Medical Immunology, 9th ed. Appleton \& Lange. 1997: 196-209.

18. Elson, C.O., and Dertzbaugh, M.T., Mucosal Adjuvants in: Ogra, P.L., Mestecky, J., Lamm, M.E., Strober, W., Bienenstock, J., McGhee, J.R., Mucosal Immunology 2nd ed, Academic Press. 1999: 817 - 838.

19. Elson, C.O., Cholera toxin as a Mucosal Adjuvant, in Ogra, P.L., Lamm, M.E., Bienenstock, J., Mestecky, J., Strober, W., McGhee, J.R., Mucosal Vaccine, Academic Press. 1996: 59 - 72.

20. Mestecky, J., McGhee, J.R., Immunoglobulin A ( $\lg A)$ : Molecular and Cellular Interactions Involved in IgA Biosynthesis and Immune response. Adv.Immunol. 1987: 40: 153 - 245.

21. Mestecky, J., Moro, I., Underdown, B.J., Mucosal Immunoglobulins in: Ogra, P.L., Mestecky, J., Lamm, M.E., Strober, W., Bienenstock, J., McGhee, J.R., Mucosal Immunology, 2nd ed., Academic Press. USA. 1999: 133 - 152.

22. Jackson, R.J., Fujihashi, K., Xu-Amanao, J., Kiyono, H., and McGhee, J.R., Optimizing Oral Vaccines: Induction of Systemic and Mucosal B cell and Antibody Responses to Tetanus Toxoid by use of Cholera Toxin as Adjuvant, Infect Immun. 1993: 61: 4272 4279.

23. Snider, D.P., Marshall, J.S., Perdue, M.H., and Liang, H., Production of IgE Antibody and Allergic Sensitization of Intestinal and Pheripheral Tissues after Oral Immunization with Protein Ag and Cholera toxin, J.Immunol. 1994: 153: 647 - 657.

24. Abbas, Abul, K., Lichtman, Andrew, H., Pober, Jordan, S., Cellular and Molecular Immunology, $4^{\text {th }}$ ed. W.B. Saunders Company. 2000: 199, 331 - 333.

25. Janeway, C.A., Travers, P., Walport, M., Capra, J.D., Immunobiology, The Immune System in Health and Disease $4^{\text {th }}$ ed., Elsevier Science Ltd/Garland Publishing. 1999: 314 - 316.

26. Bouvet, J.P., and Fischetti, V.A., Diversity of Antibody-Mediated Immunity at the Mucosal Barrier. Infect Immun. 1999: 67: 26872691.

27. Levine, M.M., and Sztein, M.B., Human Mucosal Vaccines for Salmonella typhi Infections, in: Kiyono H, Ogra PL, McGhee JR, Mucosal Vaccines. Academic Press, Inc. USA. 1996: 201 - 211. 
Hal.

ARTIKEL ASLI

ENZIM LIPOPROTEIN LIPASE SUATU ALTERNATIF PEMERIKSAAN GANGGUAN METABOLISME LEMAK PADA PENDERITA DM TIPE 2 IN VITRO

\title{
(LIPOPROTEIN LIPASE ENZYME AS AN ALTERNATIVETEST TO DIAGNOSE LIPID METABOLISM DISTURBANCES IN DIABETES TYPE 2)
}

\author{
Dian Handayani', Aulani'Am ${ }^{* *}$, Djoko W. Soeadmadji ${ }^{* * *}$, M. Aris Widodo**** \\ *Program D-IV Gizi FKUB, PS Biomedik PPSUB \\ ${ }^{*}$ Lab. Kimia Fakultas MIPA Universitas Brawijaya \\ ${ }^{* * *}$ Divisi Endokrin , Lab./UPF IImu Penyakit Dalam RSSA, FKUB \\ ${ }^{* * \star \star L a b . ~ F a r m a k o l o g i, ~ B i o m e d i k ~ F K U B ~}$
}

\begin{abstract}
The biggest population of Diabetes Mellitus is type 2 diabetes. Dyslipidemia is frequently found in type 2 diabetic patients, which is characterized by increased TG plasma levels and decreased HDL. Increased TG levels may be due to LPL activity disturbance, which then lead to impaired lipoprotein metabolism, such as decreased hydrolyzing TGs in VLDL and Chylomicron. LPL is an enzyme which activities are influenced by several factors such as temperature, $\mathrm{pH}$, incubation period, and substrate concentration. $L P L$ attached to vascular endothelium, and can be removed from it by giving heparin intravenous. Heparin acts as lipotropic agent which promote plasma lipid transfer to lipid deposit by secreting lipolitic enzyme such as LPL. After giving information about the objective of this study on the possible site effect of the blood obtaining technique, the patient was asked to give her voluntary consent. Heparin IV $60 \mathrm{IU} / \mathrm{Kg} \mathrm{BB}$ was given 15 minute before blood sample was drawn. Obtain from aid type 2 diabetes individual and aid from non diabetic control subject. To determine optimal $L P L$ action $\mathrm{pH}$ variations $(6,6.4,6.8$ and 7$)$, temperature $(30,32,35 \text { and } 37)^{\circ} \mathrm{C}$, and incubation period ( 5, 10, 15 and 20 minute) was expose in vitro. Determinant of LPL molecular weight used the SDS-PAGE (Sodium Doedecyl Sulfat Polyacrilamid Gel ElectropHoresis). The results of this study show that LPL optimal conditions were at pH 6.8 is $33.0403 \pm 6.3353$ unit (Mean $\pm S D$ ); enzyme activity at temperature $32^{\circ} \mathrm{C}$ is $32.7672 \pm 8.5757$ Unit (Mean $\pm S D$ ); enzyme activity at incubation period 15 minutes is $35.4978 \pm 15.2196$ Unit (Mean \pm SD); and at optimal activity condition that using concentration substrate 1.5\% are: $34.26 \pm 3.67$ Unit (Mean \pm SD) for type 2 diabetes and $87.37 \pm 8.87$ Unit (Mean \pm SD) for normal subject. 87.37 \pm 8.8665 Unit (Mean $\pm S D$ ). Statistical analysis ( $T$ test) show significant different between $L P L$ activity type 2 diabetes and normal subject. The electropHoresis show molecular weight of LPL around $71 \mathrm{Kda}$. There is different thickness and width of the LPL and between individual type 2 diabetes and control group. The different may be due to different enzyme concentration. These results show that for optimalization LPL activity test in vitro we need enzyme isolated from post heparin plasma with optimal conditions as follows: temperature $32^{\circ} \mathrm{C}, \mathrm{pH} 6.8$, and incubation period 15 minutes. In this optimal conditions we can compare LPL activities of diabetic type 2 with normal subjects. LPL activity in diabetic type 2 patients is lower than in normal subjects $134.26 \pm 3.67$ Unit (Mean $\pm S D$ ) VS $87.37 \pm 8.87$ Unit (Mean $\pm S D) ;(P<0.0001)$ ). The results can be tested at diabetic type 2 cases with various conditions, such as in obesity.
\end{abstract}

Key words : DM tipe 2, Enzim Lipoprotein Lipase, aterosklerosis, small dense LDL, plasma post heparin.

\section{ABSTRAK}

Populasi DM yang terbesar yaitu DM tipe 2. Pada penderita DM tipe 2 sering dijumpai adanya dislipidemi yang ditandai dengan peningkatan kadar serum trigliserida (TG) dan diikuti penurunan HDL. Peningkatan kadar TG disebabkan adanya gangguan aktivitas enzim Lipoprotein lipase (LPL). Selanjutnya mengakibatkan gangguan metabolisme lipoprotein, seperti terjadinya hidrolisis TG pada VLDL dan kilomikron akan menurun. Enzim LPL yang merupakan golongan protein aktivitas kerjanya sangat dipengaruhi oleh adanya faktor suhu, pH, waktu inkubasi dan konsentrasi substrat. Letak enzim LPL salah satunya terdapat pada endotel dinding pembuluh darah. LPL dapat dilepaskan dari dinding pembuluh darah dengan melalui pemberian heparin intra vena. Heparin bersifat lipotropik, yang memperlancar transfer lemak darah ke dalam depot lemak dengan melepaskan enzim-enzim yang menghidrolisis lemak seperti LPL. Pada penelitian ini menggunakan sampel plasma pascaheparinisasi (yaitu plasma dari subyek penelitian yang sebelumnya telah diberi heparin intravenous dengan dosis $60 \mathrm{IU} / \mathrm{kg}$ BB). Subyek penelitian terdiri atas 8 orang tanpa DM tipe 2 (normal) dan 8 orang subyek penelitian dengan DM tipe 2. Karakterisasi LPL dilakukan berdasarkan kondisi optimum dengan memberikan variasi pH (6.4; 6.8; 7 dan 7.4), suhu (30,32, 35 dan $37^{\circ} \mathrm{C}$, dan waktu inkubasi (5, 10, 15 dan 20 menit). Serta penentuan berat molekul dari LPL menggunakan metode SDS-PAGE (Sodium Doedesyl Sulfat Polyacrilamid Gel Elektroforesis). Hasil penelitian menunjukkan bahwa karakter enzim LPL mempunyai kondisi kerja optimum pada $\mathrm{pH} 6.8$, suhu $32^{\circ} \mathrm{C}$, waktu inkubasi 15 menit dan konsentrasi substrat 1.5\%. Aktivitas enzim pada pH 6.8 adalah $33.0403 \pm 6.3353$ unit (Mean \pm SD); aktivitas enzim pada suhu $32{ }^{\circ} \mathrm{C}$ adalah $32.7672 \pm$ 8.5757 Unit (Mean \pm SD); aktivitas enzim pada waktu inkubasi 15 menit adalah $35.4978 \pm 15.2196$ Unit (Mean \pm SD); dan aktivitas

Maj. Kedok. Unibraw Vol. XIX, No.2, Agustus 2003 
enzim pada suhu, $\mathrm{pH}$ dan waktu inkubasi optimum serta konsentrasi subtrat $1.5 \%$ adalah : $87.37 \pm 8.8665$ Unit (Mean \pm SD). Berat molekul LPL hasil isolasi adalah $71 \mathrm{Kda}$. Dari hasil elektroforesis juga nampak adanya perbedaan ketebalan pita protein pada kelompok sampel normal dan DM tipe 2. Perbedaan ketebalan pita ini diduga karena adanya perbedaan jumlah enzim LPL pada masing-masing kelompok. Dari hasil analisis uji statistik (uji t) menunjukkan adanya perbedaan sangat nyata $(P<0.0001)$ antara aktivitas LPL pada sampel plasma orang DM tipe 2 dan orang normal dengan nilai aktivitas pada kelompok DM tipe 2 (34.26 \pm 3.67 Unit (Mean $\pm S D))$ dan pada kelompok normal (87.37 \pm 8.87 Unit (Mean \pm SD)). Dari hasil penelitian ini untuk optimalisasi uji aktivitas LPL in vitro dibutuhkan enzim yang diisolasi dari plasma post heparin dan diberlakukan kondisi optimum sebagai berikut: suhu optimum $32^{\circ} \mathrm{C}$, pH 6.8 dan waktu inkubasi 15 menit. Dengan kondisi optimum ini dapat dibedakan aktivitas LPL pada orang dengan DM tipe 2 dan kelompok normal. Aktivitas LPL pada pasien DM tipe 2 lebih kecil bila dibandingkan dengan aktivitas LPL pada kelompok normal $(P<0.0001)$. Hasil diatas dapat diujicobakan pada berbagai kasus DM tipe 2 dengan berbagai kondisi misalnya pada kasus obesitas.

Kata kunci: DM tipe 2, Enzim Lipoprotein Lipase, aterosklerosis, small dense LDL, plasma post heparin

\section{PENDAHULUAN}

Salah satu faktor timbulnya penyakit jantung koroner (PJK) adalah dislipidemia (1). Salah satu tanda kondisi dislipidemia adalah adanya peningkatan serum lipid baik itu cholesterol maupun trigliserida serta penurunan HDL (2). Selain dislipidemia faktor resiko yang dapat menyebabkan timbulnya PJK adalah usia jenis kelamin, stress, faktor keturunan serta Diabetes mellitus (DM), kegemukan dan hipertensi.

Pada diabetes mellitus tipe 2 (NIDDM) yang merupakan populasi terbesar pada penderita DM (lebih dari $90 \%$ ) biasanya diikuti dengan gangguan metabolisme lemak, yang ditandai dengan hiperglikemia kronik dan hal ini terjadi pada DM tipe 2 dengan glukosa darah terkendali maupun tidak terkendali. Menurut Framingham Heart Study, peningkatan kadar TG dan VLDL yang disertai dengan HDL yang rendah lebih sering dijumpai pada pasien diabetes (baik laki-laki maupun wanita) dibandingkan pasien non diabetes. Kondisi dislipidemia pada DM tipe 2 akan menyertai timbulnya komplikasi jangka panjang (3).

Kadar TG yang meningkat dapat diakibatkan karena adanya gangguan aktivitas enzim Lipoprotein lipase (LPL), dan abdominal obesity serta peningkatan kadar small dense LDL diduga mempunyai hubungan yang erat dengan adanya kenaikan trigliserida, penurunan $\mathrm{HDL}$ kolesterol dan peningkatan ratio kolesterol dan HDL kolesterol. Hal ini merupakan faktor resiko adanya acute coronary syndrome. Dugi et.al,1996 yang telah melakukan penelitian tentang aktivitas LPL pada kelompok familial hypercholesterolemia, dan berkesimpulan bahwa LPL merupakan enzim yang penting dalam metabolisme lemak dan gangguan terhadap enzim ini akan mengarah pada terjadinya aterosklerosis (4).

Mengingat pengukuran small dense LDL membutuhkan biaya yang mahal untuk dilakukan maka pengukuran aktivitas enzim LPL merupakan salah satu cara sederhana yang dapat digunakan untuk mengetahui penyebab tingginya kadar TG pada DM tipe 2.

Menurut David dan Hazel, 1993, penelitian enzim yang terkandung di dalam plasma darah merupakan hal yang diperlukan di dalam biokimia klinik untuk mengawasi proses metabolisme yang normal dan mendeteksi tingkat abnormalitas dari enzim yang diproduksi oleh tubuh (5). Dalam Lehninger, 1995 dikatakan bahwa enzim memiliki kondisi optimum tertentu untuk dapat beraktivitas secara optimum karena itu dalam penelitian ini akan digunakan suatu metode uji aktivitas LPL pada penderita DM tipe 2 dengan tahapan sebelumnya mengisolasi enzim LPL dari plasma post heparin dilanjutkan dengan mencari kondisi kerja optimum enzim LPL pada orang normal meliputi suhu, waktu inkubasi, pH dan konsentrasi substrat optimum (6). Dengan cara sentrifugasi dan titrasi enzim LPL diharapkan dapat diketahui aktivitas LPL pada metabolisme lemak baik pada kelompok subyek penelitian normal maupun dengan DM tipe 2 .

Berdasarkan uraian di atas, maka dirumuskan suatu permasalahan, bagaimana kondisi optimum (meliputi pH, waktu inkubasi dan suhu) reaksi enzimatis dari LPL hasil isolasi dari plasma darah subyek penelitian, karakter LPL berdasarkan kinetika reaksi enzimatis $(\mathrm{Km}, \mathrm{Vm})$, aktivitas dan berat molekulnya (SDS - PAGE) dan bagaimana perbedaan aktivitas enzim LPL dari plasma post heparin orang normal dan DM tipe 2 terhadap substrat.

Dengan penelitian ini diharapkan diperloeh suatu manfaat yaitu mendapatkan kondisi optimum metoda pemeriksaan enzimatis LPL pada penderita DM tipe 2 dan mendapatkan alternatif tehnik pemerikasaan gangguan metabolisme lemak pada penderita DM tipe 2 melalui pemeriksaan LPL.

\section{METODOLOGI}

\section{Subjek penelitian}

Subyek penelitian dikelompokkan dalam dua kelompok yaitu 8 orang dengan DM tipe 2 dan 8 orang dalam kondisi tidak DM. Karakteristik untuk masing-masing kelompok adalah jenis kelamin laki-laki, usia di atas 40 tahun, bukan perokok, Cloting time dan bleeding time normal, tidak alergi heparin. Setiap subyek penelitian yang akan disertakan dalam penelitian ini telah diberikan inform consent dan ditandangani oleh subyek penelitian. Selain itu juga diberi form ijin pelaksanaan penelitian dari komite etik penelitian. Untuk kelompok normal kriteria ditambah dengan tidak menderita DM tipe 2 secara klinis (gula darah 2 pp normal).

\section{Bahan}

Bahan yang digunakan dalam penelitian ini mempunyai kemurnian p.a, bahan-bahan tersebut adalah Etanol 99\%, Sukrosa, PLP (piridoxial pHospHat), AET (aminoetilitsotioruium bromid), $\mathrm{Na}_{2}$-EDTA, Aquades, Buffer pHospHat $\mathrm{pH}=7$, Olive oil, $\mathrm{NaOH}, \mathrm{PMSF}$ (PHenylmethylsulfonilfluorid), Asam Oleat, Indikator $\mathrm{pp},(\mathrm{NH})_{2} \mathrm{SO}_{4}$, Asam asetat glasial, Akrilamida, Bis-akrilamida, Amonium persulfat (APS), N,N,N',N' tetrametietilen diamine (TEMED), Sodium dodesil sulfat (SDS), Bovin Serum Albumin, $\mathrm{CuSO}_{4} .5 \mathrm{H}_{2} \mathrm{O}, \mathrm{HCL}, \mathrm{BaCl}_{2}$. Metode penelitian ini adalah deskriptif analitik. 
Tahapan yang dilakukan pada penelitian ini adalah sebagai berikut :

\section{Pengambilan sampel}

Pengambilan sampel dilakukan setelah subyek penelitian puasa 10 - 12 jam (subyek boleh minum air putih). Sebelum sampel diambil, subyek duduk selama 5 menit, kemudian dilakukan uji alergi heparin dengan cara memberikan heparin yang telah diencerkan menjadi 1/1000, kemudian dilakukan penyuntikan intra kutan dengan heparin yang telah diencerkan hingga berbentuk bulatan kecil, bulatan kecil diberi tanda dengan meggunakan ballpoint. Bila bulatan tidak membesar maka dikatakan tidak alergi heparin, demikian pula sebaliknya. Selanjutnya apabila tidak mengalami alergi heparin, subyek diberikan heparin Intra venous 60 IU/KG BB. 15 menit kemudian pengambilan sampel dilakukan dengan melakukan bendungan vena seminimal mungkin. Bahan yang diambil adalah serum.

\section{Isolasi Enzim}

Isolasi Enzim Lipoprotein Lipase (LPL) dilakukan dengan menggunakan metode sentrifugasi. (Modifikasi metode oleh Sumner and Myrback, 195 In, Wharton D.C and R.E Casty, 1972) (7).

\section{Penentuan Kondisi Optimum}

Penentuan $\mathrm{pH}$ optimum dilakukan pada enzim hasil isolasi dari plasma post heparin dengan variasi pH sebesar $6.4 ; 6.8 ; 7.0$ dan 7.4 dan diukur pada suhu $37{ }^{\circ} \mathrm{C}$. Kemudian dilakukan pengukuran aktivitas sebagaimana prosedur. Selanjutnya diplot antara besar $\mathrm{pH}$ dengan aktivitas crude enzymem. Nilai Unit terbesar menunjukkan tercapainya $\mathrm{pH}$ optimum.

\section{Penentuan suhu Optimum}

Penentuan suhu optimum dilakukan pada enzim hasil isolasi dari plasma post heparin dengan variasi suhu sebesar: 30 ${ }^{\circ} \mathrm{C}, 32^{\circ} \mathrm{C}, 35^{\circ} \mathrm{C}, 37^{\circ} \mathrm{C}$ dan diukur pada $\mathrm{PH}$ optimum. Kemudian dilakukan pengukuran aktivitas crude enzyme. Dan diplot antara besarnya suhu dengan aktivitas crude enzyme. Nilai Unit terbesar menunjukkan tercapainya suhu optimum.

\section{Penentuan waktu inkubasi optimum}

Penentuan waktu inkubasi optimum dilakukan pada enzim hasil isolasi dari plasma post heparin dengan variasi waktu inkubasi sebesar 5 menit, 10 menit, 15 menit, 20 menit pada $\mathrm{pH}$ dan suhu optimum. Kemudian dilakukan pengukuran aktivitas crude enzyme. Dan diplot antara besarnya suhu dengan aktivitas crude enzyme. Nilai Unit terbesar menunjukkan tercapainya waktu inkubasi optimum.

\section{Pemurnian Enzim Kasar Lipoprotein Lipase (LPL)}

Enzim kasar LPL dimurnikan dengan metode pengendapan bertingkat menggunakan amonium sulfat, dengan fraksi endapan 60-90\%. Selanjutnya dilakukan dialisis dengan kantong selofan dan direndam dalam buffer phosphat $\mathrm{pH} 7$ untuk memisahkan enzim dari komponen terlarut lainnya, kemudian dilakukan uji aktivitas.

\section{Penentuan Berat Molekul LPL}

Elektroforesis, dilakukan untuk mengetahui berat molekul enzim dan untuk menunjukkan bahwa enzim yang diisolasi adalah enzim liporotein lipase

Penentuan masa molekul realtif (BM) dari LPL dilaukan dengan SDS PAGE. Untuk menentukan massa molekul relatif enzim, maka dilakukan dengan menghitung $\operatorname{Rf}($ Retardaction Factor) dari masing-masing pita, dimana:

$$
\mathrm{Rf}=\frac{\text { Jarak pergerakan pita dari tempat awal }}{\text { Jarak pergerakan warna dari tempat awal }}
$$

Nilai Rf yang diperoleh diplotkan dengan kurva kalibrasi hubungan antara $\mathrm{Rf}$ dengan berat molekul dari protein standar.

\section{Penentuan Konstanta Kinetika Reaksi}

Penentuan konstanta kinetika reaksi crude enzyme LPL yang terdiri dari harga KM dan Vmaks. Dilakukan dengan menguji aktivitas crude enzyme LPL hasil isolasi dari plasma post heparin, pada kondisi optimum dengan variasi substrat sebesar $0.5 \%, 1 \%$, $1.5 \%$,dan $2 \%$ (dalam $\%$ volume per volume). Kemudian dibuat kurva Hanes, yaitu hubungan antara [S] dan [S]/Vo. Berdasarkan kurva tersebut dapat dihitung $\mathrm{V}$ maks dan $\mathrm{Km}$ crude enzyme Lipoprotein lipase.

\section{Uji aktivitas crude enzyme LPL berdasarkan kondisi optimum}

Aktivitas LPL adalah kemampuan LPL dalam menghidrolisa trigliserida (8). Satu unit aktivitas enzim LPL adalah didefinisikan sebagai jumlah mikromol dari asam lemak bebas (FFA) per mililiter enzim permenit perdesiliter darah pada kondisi optimum. Rumus yang digunakan:

$$
\text { AKTIVITAS }=\frac{\mathrm{N} \mathrm{NaOH} \times V \mathrm{NaOH} \times \mathrm{T} \times \mathrm{fp}}{\operatorname{VE} \times \mathrm{T}}
$$

\begin{tabular}{ll}
\multicolumn{2}{l}{ Keterangan } \\
$\mathrm{N} \mathrm{NaOH}$ & $:$ Konsentrasi $\mathrm{NaOH}$ \\
$\mathrm{V} \mathrm{NaOH}$ & $:$ Volume $\mathrm{NaOH}$ \\
$\mathrm{fp}$ & $:$ Faktor pengenceran \\
$\mathrm{VE}$ & $:$ Volume Enzim
\end{tabular}

Aktivitas enzim diukur dengan cara menambahkan enzim pada larutan substrat, kemudian diinkubasikan pada inkubator sesuai dengan kondisi optimumnya, setelah itu enzim dipanaskan pada suhu $100^{\circ} \mathrm{C}$ selama 10 menit, kemudian dititrasi dengan $\mathrm{NaOH} 0.1 \mathrm{M}$ sampai terjadi perubahan warna. Selanjutnya aktivitas diukur dengan menggunakan rumus di atas.

\section{ANALISA DATA}

Data lainnya yang diperoleh dianalisis dengan cara membuat deskripsi karakter ezim LPL pada masing-masing subyek dan aktivitas enzim pada kelompok DM tipe 2 dan normal dibandingkan dan diuji sacara statistik untuk mengetahui ada beda aktivitas dengan menggunakan uji $\mathrm{T}$. 
Hal.

HASIL

Dari hasil isolasi enzim lipoprotein lipase (LPL) dari plasma post heparin didapatkan crude enzyme LPL. Selanjutnya crude enzyme ini digunakan untuk mencari kondisi optimum kerja enzim secara in vitro

Penetuan Kondisi Kerja Optimum Enzim LPL Hasil Isolasi

Enzim hasil isolasi ditentukan kondisi optimumnya berdasarkan variasi $\mathrm{pH}(6.0 ; 6.4 ; 7.0$; dan 7.4$)$, suhu (30; $32 ; 35$ dan 37$)^{\circ} \mathrm{C}$,dan waktu inkubasi (10; 15; 20 dan 25 ) menit.

Penentuan pH Optimum

Dari hasil penentuan $\mathrm{pH}$ optimum enzim LPL didaptkan $\mathrm{pH}$ optimum sebesar $6,8^{\circ} \mathrm{C}$ Aktivitas enzim LPL pada masingmasing variasi $\mathrm{pH}$ tersebut dapat dilihat pada Tabel 1.

Tabel 1. Nilai aktivitas rata-rata crude enzyme LPL pada beberapa variasi $\mathrm{pH}$.

\begin{tabular}{|c|c|c|c|}
\hline No & pH & $\begin{array}{c}\text { AKTIVITAS RATA-RATA } \\
\text { (UNIT) (MEAN } \pm \text { SD) }\end{array}$ & $\begin{array}{c}\text { HASIL UJI } \\
\text { BEDA }\end{array}$ \\
\hline 1 & 6.4 & $29.8025 \pm 3.9040$ & \multirow{2}{*}{$\begin{array}{c}\mathrm{P}=10.7279 \\
\text { P }=0.0001\end{array}$} \\
\hline 2 & 6.8 & $33.0403 \pm 6.3353$ & \\
\cline { 1 - 2 } 3 & 7 & $23.7562 \pm 3.7724$ & \multirow{1}{*}{} \\
\hline 4 & 7.4 & $21.5717 \pm 3.7724$ & \\
\cline { 1 - 2 }
\end{tabular}

Dari Table 1 terlihat bahwa variasi $\mathrm{pH}$ memberikan nilai aktivitas crude enzyme LPL yang berbeda-beda. Pada penelitian ini, $\mathrm{pH}$ optimum dicapai pada $\mathrm{pH} 6.8$ dengan aktivitas rata-rata crude enzyme LPL ini sebesar 33.0403 unit.

\section{Penentuan Suhu Optimum}

Penentuan suhu optimum enzim LPL dilakukan pada variasi suhu $(30 ; 32 ; 35 \text {; dan } 37)^{\circ} \mathrm{C}$, dan di ukur pada $\mathrm{pH} 6.8$ dan waktu inkubasi selama 15 menit. Aktivitas enzim LPL pada masing-masing variasi suhu tersebut dapat dilihat pada Tabel 2 .

Tabel 2. Nilai aktivitas rata-rata crude enzyme LPL pada beberapa variasi suhu pada $\mathrm{pH} 6.8$

\begin{tabular}{|l|c|c|c|}
\hline No & Suhu $\left({ }^{\circ} \mathrm{C}\right)$ & $\begin{array}{c}\text { AKTIVITAS RATA-RATA } \\
\text { (UNIT) (MEAN } \pm \text { SD) }\end{array}$ & HASIL UJI BEDA \\
\hline 1 & 30 & $21.0256 \pm 6.0603$ & $\mathrm{~F}=4.9184$ \\
\hline 2 & 32 & $32.7672 \pm 8.5757$ & $\mathrm{P}=0.0072$ \\
\hline 3 & 35 & $32.2211 \pm 7.0785$ & \\
\hline 4 & 37 & $31.1288 \pm 5.8090$ & \\
\hline
\end{tabular}

Dari tabel 2 terlihat bahwa variasi suhu memberikan nilai aktivitas crude enzyme LPL yang berbeda-beda. Uji aktivitas dimulai pada suhu $30^{\circ} \mathrm{C}$ kemudian suhu meningkat pada $32^{\circ} \mathrm{C}$ dan menurun kembali pada suhu $35^{\circ} \mathrm{C}$ dan $37^{\circ} \mathrm{C}$. Pada penelitian ini, suhu optimum dicapai pada suhu $32^{\circ} \mathrm{C}$ dengan aktivitas ratarata crude enzyme sebesar 32.7672 unit .

\section{Penentuan Waktu Inkubasi Optimum}

Penentuan waktu inkubasi optimum enzim LPL dilakukan pada variasi waktu inkubasi (10; 15; 20; dan 25 ) menit, dan diukur pada $\mathrm{pH} 6.8$ dan suhu $32^{\circ} \mathrm{C}$. Aktivitas enzim LPL pada masing-masing variasi waktu inkubasi tersebut dapat dilihat pada Tabel 3.
Tabel 3. Nilai aktivitas rata-rata crude enzyme LPL pada beberapa variasi waktu inkubasi, pada $\mathrm{pH} 6.8$ dan suhu $32^{\circ} \mathrm{C}$

\begin{tabular}{|c|c|c|c|}
\hline No & $\begin{array}{c}\text { Waktu } \\
\text { (menit) }\end{array}$ & $\begin{array}{c}\text { AKTIVITAS RATA-RATA } \\
\text { (UNIT) (MEAN } \pm \text { SD) }\end{array}$ & $\begin{array}{c}\text { HASIL UJI } \\
\text { BEDA }\end{array}$ \\
\hline 1 & 5 & $30.5827 \pm 4.6706$ & $\mathrm{~F}=4.9932$ \\
\hline 2 & 10 & $26.7599 \pm 2.5675$ & $\mathrm{P}=0.0067$ \\
\hline 3 & 15 & $35.4978 \pm 15.2196$ & \\
\cline { 1 - 3 } 4 & 20 & $20.2064 \pm 2.1457$ & \\
\hline
\end{tabular}

Dari Tabel 3 terlihat bahwa variasi waktu inkubasi memberikan nilai aktivitas crude enzyme LPL yang berbedabeda. Uji aktivitas dimulai dengan waktu inkubasi 5 menit, kemudian ditingkatkan menjadi 10 menit. Disini tampak adanya sedikit penurunan aktivitas. Selanjutnya waktu inkubasi ditingkatkan kembali menjadi 15 menit, dan aktivitas meningkat kembali selanjutnya waktu ditingkatkan lagi hingga mencapai 20 menit, namun aktivitas enzim menurun kembali. Pada penelitian ini, waktu inkubasi optimum dicapai pada waktu 15 menit dengan aktivitas enzim sebesar 35.4978 unit.

\section{Penentuan Harga KM dan Vmaks}

Penentuan harga Harga KM dan Vmaks dilakukan dengan cara mengukur kecepatan rata-rata crude enzyme LPL pada posisi optimumnya, dengan variasi konsentrasi substrat yang dinyatakan pada tabel 4 .

Tabel 4. Kecepatan reaksi rata-rata crude enzyme LPL pada berbagai variasi konsentrasi substrat, pada $\mathrm{pH} 6.8$; suhu $32^{\circ} \mathrm{C}$ dan waktu inkubasi selama 15 menit

\begin{tabular}{|c|c|c|c|}
\hline No & {$[\mathbf{S}] \%$} & $\begin{array}{c}\text { Kecepatan reaksi (Unit) } \\
\text { (Mean } \pm \text { SD) }\end{array}$ & Hasil Uji Beda \\
\hline 1 & 0.5 & $20.21 \pm 5.31889$ & \multirow{F}{*}{$\mathrm{F}=451,5632$} \\
\hline 2 & 1.0 & $47.48 \pm 1.46455$ & \multirow{2}{*}{$\mathrm{N}=0,0001$} \\
\hline 3 & 1.5 & $87.37 \pm 8.86650$ & \\
\hline 4 & 2.0 & $124.02 \pm 6.12760$ & \\
\hline
\end{tabular}

Penentuan kinetika enzim menurut Lehninger, 1995 dapat ditentukan berdasarkan pada nilai $\mathrm{Km}$ dan VM. Untuk menentukan kecepatan reaksi kinetika enzim dilakukan dengan memberikan variasi konsentrasi substrat dengan konsentrasi enzim tetap. Hal ini karena konsentrasi enzim yang tetap dan konsentrasi substrat yang semakin besar akan menyebabkan kenaikan aktivitas enzim, karena dengan meningkatnya konsentrasi substrat, maka semakin banyak enzim yang berikatan dengan substrat, sehingga produk yang dihasilkan akan banyak. Meningkatnya aktivitas enzim ini akan mencapai maksimum jika semua enzim telah mengikat substrat atau enzim telah jenuh oleh substrat. 


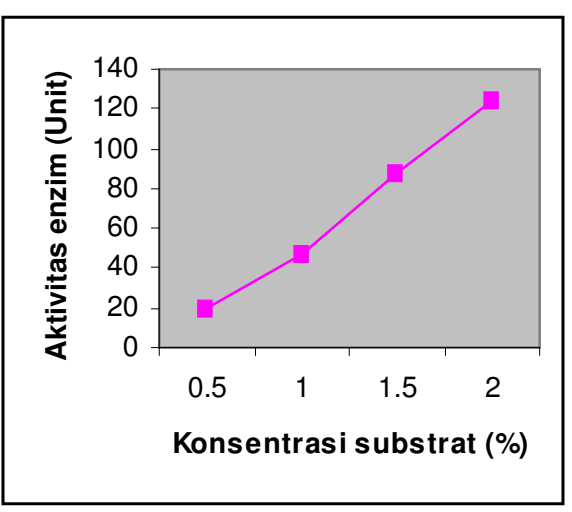

Gambar 1. Pengaruh variasi konsentrasi substrat terhadap aktivitas enzim LPL

Harga KM dan Vmaks ditentukan dengan menggunakan persamaan Hanes. Dari Tabel 4. disubstitusikan harga [S] pada sumbu $x$ dan $[S] / V$ pada sumbu y.

Dari perhitungan harga KM dan Vmaks, diperoleh besarnya kecepatan maksimum (Vmaks) crude enzyme LPL dalam menghidrolisis substrat adalah 4.61017 dalam mmol produk terbentuk/gr protein enzim/detik dan konsentrasi substrat pada saat kecepatan mencapai setengah dari kecepatan maksimum $\left(\mathrm{K}_{\mathrm{M}}\right)$ adalah $36,6747 \mathrm{mmol} / \mathrm{dm}^{3}$

Dari Gambar 1 terlihat bahwa semakin tinggi konsentrasi substrat, maka semakin tinggi pula kecepatan reaksi enzimatis ekstrak kasar enzim LPL sampai pada konsentrasi yang lebih tinggi lagi akan menghasilkan kecepatan reaksi yang konstan, mengikuti persamaan : $y=-0.0059 x+0.0272$

\section{Penentuan Massa Molekul Relatif}

Enzim yang telah dimurnikan pada fraksi endapan ke 3 dilektroforesis dengan menggunakan gel poliakrilamida. Hasil elektroforesis ditunjukkan pada gambar elektroforegam berikut:

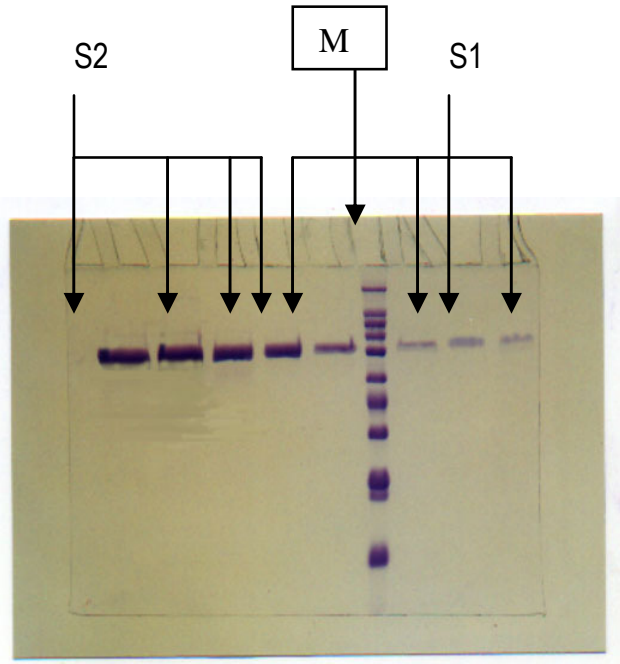

Gambar 2. Elektroforegam dari enzim LPL yang diisolasi dari plasma post heparin kelompok sampel normal dan DM tipe 2

Keterangan :

M : Marker (Protein standar)

S1 : Sampel Kontrol/Normal

S2 : Sampel dengan DM Tipe II
Dari hasil diatas dapat dilihat bahwa nilai massa molekul relatif enzim LPL adalah $71 \mathrm{kDa}$. Menurut Schomburg (1991), masaa molekul relatif enzim LPL yaang diisolasi dari manusia, tikus dan burung sebesar 34.000-75.000 Dalton, sehingga diduga pita protein tersebut adalah pita protein dari enzim LPL (9).

Pada Gambar 2 di atas nampak adanya perbedaan ketebalan band pada sampel normal dan sampel DM.

\section{Aktivitas LPL Pada Penderita DM}

Dari hasil penelitian yang telah dilakukan pada 8 orang penderita DM tipe 2 menunjukkan nilai rata-rata dari aktivitas enzim LPL adalah sebesar 34.26 unit/menit. Dan hal ini menunjukkan adanya perbedaan dengan nilai aktivitas LPL pada kelompok normal (87.37 unit/menit) seperti tampak pada gambar di bawah ini :

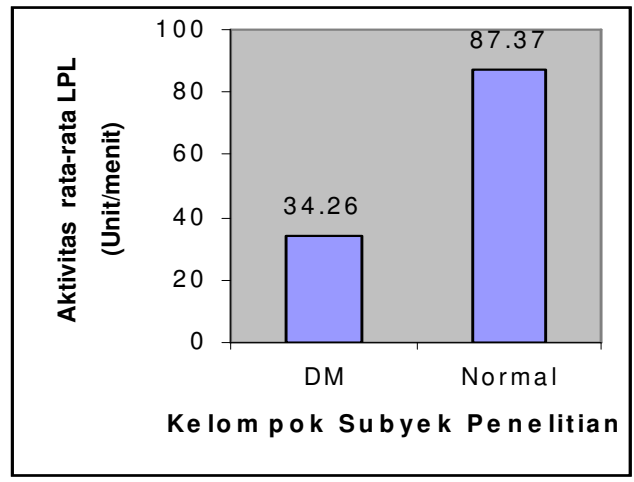

\section{Gambar 3. Perbedaan aktivitas rata-rata enzim LPL pada kelompok DM tipe 2 dan kelompok normal}

Selanjutnya dengan menggunakan uji statistik T-test membuktikan adanya perbedaan antara kedua nilai aktivitas di atas dengan $p$ value 0.0001 .

\section{PEMBAHASAN}

Dari plasma post heparin dapat diisolasi enzim LPL, selanjutnya hasil isolasi ini diuji aktivitasnya. Enzim hasil isolasi ditentukan kondisi optimumnya berdasarkan variasi $\mathrm{pH}(6.0 ; 6.4$; 7.0;dan 7.4), suhu (30; $32 ; 35$ dan 37$)^{\circ} \mathrm{C}$, dan waktu inkubasi (10; 15; 20 dan 25) menit. Hal ini mengingat setiap enzim mempunyai kondisi kerja optimum yang berbeda tergantung dari jenis dan sumber enzim tersebut (10). Kondisi kerja optimum LPL ditentukan besar nilai aktivitas enzim yang tertinggi dengan satuan unit. Satu unit aktivitas enzim LPL didefinisikan sebagai jumlah mikromol asam lemak yang dibebaskan permililiter enzim per menit pada kondisi optimumnya.

Dari hasil penentuan $\mathrm{pH}$ optimum menunjukkan variasi $\mathrm{pH}$ memberikan nilai aktivitas crude enzyme LPL yang berbedabeda. Pada penelitian ini, $\mathrm{pH}$ optimum dicapai pada $\mathrm{pH} 6.8$ dengan aktivitas rata-rata crude enzyme LPL ini sebesar 32.767 unit/menit. pH optimum merupakan $\mathrm{pH}$ dimana enzim dan substrat berada pada tingkat ionisasi yang diinginkan, yaitu gugus pemberi dan penerima proton pada sisi aktif enzim berada pada konformasi yang sesuai substrat, sehingga aktivitas enzim untuk mengikat substrat menjadi maksimum.

Pada $\mathrm{pH}$ rendah yatu dibawah $\mathrm{pH} 6.8$, konsentrasi ion $\mathrm{H}^{+}$ yang tinggi akan berikatan dengan gugus yang bermuatan 
Hal.

negatif, yaitu gugus amino (NH2), baik pada substrat maupun pada enzim, sehingga akan membentuk gugus yang bermuatan positif $\left(\mathrm{NH}_{3}+\right)$. Hal ini disebabkan reaksi yang terjadi antara trigliserida (substrat) dengan protein (enzim LPL), sehingga akan terjadi tolakan pada sisi enzim yang bermuatan sama sehingga sisi aktif enzim akan mengalami perubahan konformasi dan enzim menjadi terdenaturasi.

Pada $\mathrm{pH}$ tinggi yaitu $\mathrm{pH}$ diatas 6.8 , diduga terjadi perubahan muatan gugus ionik enzim pada sisi aktifnya, yaitu dengan berubahnya gugus karboksilat $(\mathrm{COOH})$ dari tidak bermuatan menjadi bermuatan negatif (COO-), karena terjadi pelepasan ion $\mathrm{H}+$ untuk menyetimbangkan banyaknya ion $\mathrm{OH}+$ yang disebabkan adanya penambahan $\mathrm{NaOH}$. Untuk mengkondisikan $\mathrm{pH}$ substrat kemudian ditambahkan buffer fosfat $\mathrm{pH}$ yang sesuai dengan $\mathrm{pH}$ larutan subtrat yang diinginkan. Selanjutnya $\mathrm{pH}$ optimum yang didapatkan di atas digunakan untuk mencari pengaruh perlakuan suhu dan waktu inkubasi optimum.

Penentuan suhu optimum enzim LPL dilakukan pada variasi suhu $(30 ; 32 ; 35 \text {; dan } 37)^{\circ} \mathrm{C}$, dan di ukur pada $\mathrm{pH} 6.8$ dan waktu inkubasi selama 15 menit. Aktivitas enzim LPL pada masing-masing variasi suhu tersebut dapat dilihat pada tabel 4.2. Suhu optimum dicapai pada suhu $32^{\circ} \mathrm{C}$ dengan aktivitas enzim rata-rata 32.7672 unit. Peningkatan suhu menyebabkan peningkatan energi kinetik molekul tersebut, sehingga frekuensi tumbukan antara molekul-molekul enzim dengan substrat akan semakin besar dan sehingga mengakibatkan produk enzim LPL yang dihasilkan akan menjadi maksimum.

Suhu di atas dan dibawah suhu optimum memiliki aktivitas enzim yang lebih kecil dari rata 32.7672 unit. Pada suhu di bawah suhu optimum, energi kinetik molekul enzim akibat kenaikan suhu belum mampu menghasilkan daya katalitik yang optimum. Sedangkan pada suhu di atas suhu optimum yaitu $35^{\circ} \mathrm{C}$ dan $37^{\circ} \mathrm{C}$ kecepatan reaksinya menurun kembali. Hal ini diperkirakan karena ikatan-ikatan pada enzim mulai terputus, sehingga struktur alamiah proetin enzim menjadi rusak.

Kerja katalitik enzim sangat dipengaruhi oleh suhu, seperti yang terjadi juga pada reaksi kimia lainnya (11). Pada umumnya suhu semakin tinggi maka aktivitasnya akan meningkat. Namun mengingat enzim merupakan protein, maka peningkatan suhu di atas suhu optimumnya akan berakibat proses inaktivasi akan meningkat pula. Hal ini sesuai dengan pendapat Kusnawijaya, 1983 bahwa pada suhu yang terlalu tinggi untuk enzim yang merupakan protein maka akan terjadi denaturasi yang menyebabkan sisi aktif enzim dan enzim secara keseluruhan mengalami denaturasi (12).

Waktu inkubasi adalah waktu yang diperlukan oleh enzim untuk berikatan dengan substrat. Pada waktu inkubasi yang kecil, maka aktivitas enzim juga akan kecil. Hal ini disebabkan karena waktu untuk berinteraksi antara enzim dan substrat yang kecil mengakibatkan interakasi tidak berlangsung secara keseluruhan sehingga produk yang dihasilkan hanya sedikit. Hal ini nampak pada kecilnya aktivitas crude enzyme pada waktu inkubasi 5 dan 10 menit dibandingkan dengan waktuinkubasi 15 menit.

Bila waktu inkubasi diperbesar, maka akan semakin banyak enzim yang berikatan dengan substrat, sehingga produk yang dihasilkan semakin besar, seperti terlihat pada aktivitas crude enzyme LPL yang tinggi pada waktu inkubasi 15 menit.
Apabila waktu inkubasi diperbesar maka enzim akan jenuh oleh substrat, dan kelebihan substrat tidak akan diikat oleh enzim, maka produk yang dihasilkan tetap.

Nilai aktivitas akan mengalami penurunan pada waktu 20 menit. Hal ini disebabkan karena perhitungan aktivitas enzim akan melibatkan faktor waktu sebagai pembagi, sehingga makin besar waktu inkubasi akan makin besar pembaginya sehingga nilai aktivitas yang dihasilkan akan semakin kecil. Menurut Montgomery (1993) pemecahan trigliserida dikatalisis oleh lipoprotein lipase. Dalam waktu 15 menit setelah sekresinya, lipoprotein kekurangan sebagian besar trigliseridanya, selanjutnya partikel sisanya akan diambil oleh hati (13).

Selanjutnya waktu inkubasi optimum yang didapatkan di atas, digunakan untuk menentukan harga $\mathrm{Km}$ dan Vmaks. Penentuan harga Harga KM dan Vmaks dilakukan dengan cara mengukur kecepatan rata-rata crude enzyme LPL pada posisi optimumnya ( $\mathrm{pH} 6.8$, suhu $32^{\circ} \mathrm{C}$, dan waktu inkubasi 15 menit), dengan variasi konsentrasi substrat $0.5 \%, 1.0 \%, 1.5 \%$, dan $2 \%$. Penentuan kinetika enzim menurut Lehninger 1995 dapat ditentukan berdasarkan pada nilai $\mathrm{Km}$ dan Vmaks (6). Untuk menentukan kecepatan reaksi kinetika enzim dilakukan dengan memberikan variasi konsentrasi substrat dengan konsentrasi enzim tetap. Hal ini karena konsentrasi enzim yang tetap dan konsentrasi substrat yang semakin besar akan menyebabkan kenaikan aktivitas enzim, karena dengan meningkatnya konsentrasi substrat, maka semakin banyak enzim yang berikatan dengan substrat, sehingga produk yang dihasilkan akan banyak. Seperti tampak pada Tabel 1 dan Gambar 2, konsentrasi substrat yang semakin besar menyebabkan banyak enzim yang berikatan dengan substrat sehingga banyak produk yang dihasilkan. Meningkatnya aktivitas enzim ini akan mencapai maksimum jika semua enzim telah mengikat substrat atau enzim telah jenuh oleh substrat.

Penetapan nilai $\mathrm{Km}$ dan Vmaks dilakukan dengan membuat grafik [S] $N$ pada sisi ordinat versus [S] pada sisi aksis. Dari grafik ini ditemukan persamaan grafik $y=-0.0059 x+0.0272$ dan dihasilkan harga $V$ maks $=36.76471$ dan $\mathrm{Km}=-0.21691$

Harga KM dan Vmaks ditentukan dengan menggunakan persamaan Hanes. Dari Tabel 4 disubstitusikan harga [S] pada sumbu $x$ dan $[S] / V$ pada sumbu $y$.

Penentuan harga $\mathrm{Km}$ dan $\mathrm{V}$ maks digunakan regresi linier dengan maksud untuk melihat apakah ada hubungan antara variasi konsentrasi substrat dengan kecepatan reaksi crude enzyme LPL. Dari Gambar 1 terlihat bahwa semakin tinggi konsentrasi substrat, maka akan semakin tinggi pula kecepatan reaksi enzimatis crude enzyme LPL sampai pada konsentrasi yang lebih tinggi lagi akan menghasilkan kecepatan yang konstan, mengikuti persamaan : $y=-0.0059 x+0.0272$

Berdasarkan nilai Vmaks diketahui bahwa aktivitas LPL maksimum sangat dipengaruhi oleh [S]. Pada kondisi gangguan lipid terjadi peningkatan [TG] sebagai subtrat sehingga LPL jenuh terhadap subtratnya sehingga terjadi penurunan aktivitas LPL.

Pada Gambar 2 nampak adanya perbedaan ketebalan band pada sampel normal dan sampel DM. Perbedaan ini diduga disebabkan karena jumlah LPL pada orang DM tipe 2 lebih banyak dibandingkan dengan orang normal. Peningkatan jumlah LPL ini dapat dikaitkan dengan tingginya kadar trigliserida pada 
orang DM $(170 \mathrm{mg} / \mathrm{dl})$ dibandingkan dengan kadar trigliserida pada orang normal $(152.5 \mathrm{mg} / \mathrm{dl})$.

Seperti yang dikatakan oleh Tjokroprawiro, 1994 pada penderita DM tipe 2 dislipidemia yang sering terjadi adalah adanya peningkatan serum trigliserida dan penurunan serum $\mathrm{HDL}$ (14). Namun pada orang DM tipe 2 walaupun jumlah LPL lebih banyak aktivitasnya lebih rendah dibandingkan dengan pada orang normal, hal ini disebabkan karena salah satu aktivator kerja LPL adalah insulin dan pada orang DM tipe 2 terjadi defisiensi insulin akibat kegagalan respon jaringan terhadap insulin (resistensi insulin). Dan adanya gangguan produksi insulin dapat dilihat dari hasil pemeriksaan C-peptide yang menunjukkan adanya penurunan pada kelompok DM $(1,005 \mathrm{ng} / \mathrm{dl})$ sedangkan pada orang normal sebesar $(2.7 \mathrm{ng} / \mathrm{dll})$. Hal tersebut di atas juga di dukung dengan pendapat Howard \& Howard 1994, bahwa pada NDDM, defisiensi insulin terjadi akibat kegagalan respon jaringan terhadap insulin (resistensi insulin) (15). Kelainan yang jelas terlihat adalah adanya peningkatan kadar trigliserida dan VLDL sebagai akibat terjadinya pertambahan mobilisasi glukosa dan asam lemak bebas ke hepar. Selain itu aktivitas LPL juga mengalami penurunan yang mengakibatkan klirens VLDL menjadi terganggu, dan hal ini biasa terjadi pada penderita hiperglikemia berat.

Pada DM tipe II, kadar apo A-I akan menurun tetapi kadar apo-B, apo E serta rasio apo C-III/apoC-II akan meningkat (16). Perubahan komposisi VLDL sebagai akibat bertambahnya proporsi apo $E$ dan glikosilasi apo $E$ mengganggu ikatan apo $E / B$ dan menghambat terjadinya uptake sisa VLDL oleh hepar, disamping adanya proses enrichment VLDL oleh apo C-III yang menghambat kerja LPL. Hal-hal tersebut diatas akan mengakibatkan peningkatan kadar VLDL dan juga kilomikron yang berarti juga terjadi peningkatan trigliserida.

Penelitian epidemiologis menunjukkan bahwa hipertrigliseridemia merupakan faktor resiko timbulnya penyakit kardio vaskular pada penderita DM tipe II. Adanya hyper TG akan meningkatkan aktifitas Herpatic lipase (HL) sehingga berakibat pada peningkatan katabolisme HDL. Dan telah diketahui bahwa penurunan $1 \mathrm{mg} \mathrm{HDL}$ akan meningkatkan resiko PJK sampai 3 kali lebih tinggi.

Adanya perbedaan aktivitas LPL pada kelompok normal dan kelompok DM tipe 2 menunjukkan bahwa penurunan aktivitas LPL terjadi pada kelompok DM tipe 2. Rendahnya nilai aktivitas LPL pada orang DM dibandingkan dengan kelompok kontrol diduga disebabkan karena rendahnya aktivitas insulin pada penderita DM seperti tampak pada hasil laboratoriumnya yaiu nilai rata-rata C-Peptide kelompok DM adalah sebesar $0.7 \mathrm{ng} / \mathrm{dl}$ sedangkan pada kelompok normal adalah $2.7 \mathrm{ng} / \mathrm{dl}$. Seperti dikatakan oleh Marks,1996 bahwa salah satu penyebab yang mempengaruhi aktivitas LPL adalah insulin (17). Penurunan aktivitas insulin dapat menurunkan aktivitas LPL. Hubungan antara resistensi insulin dan metabolisme trigliserida pada Very Low Density Lipoprotein (VLDL) dan apo-B adalah bahwa insulin selain berperan pada proses ambilan glukosa juga mempunyai peranan menurunkan Free Fatty Acid (FFA) Plasma melalui aktivasi enzim Liporprotein Lipase (LPL). Dan insulin juga berperanan pada stimulir sekresi apo $B$ dari hati. Akibat turunnya aktivitas LPL kadar trigliserida di dalam darah menjadi tinggi. Hal ini mengakibatkan timbulnya bentuk-bentuk abnormal dari HDL dan LDL, dimana bentuk LDL dan HDL menjadi lebih kecil dan mempunyai densitas yang lebih tinggi serta VLDL dan sisa kholesterol mengandung banyak kolesterol. Hal ini disebabkan dengan kadar trigliserida yang tinggi akan memacu kerja CETP untuk memindahkan trigliserida dari VLDL dan IDL ke LDL dan HDL. Dan sebaliknya memindahkan lebih banyak kolesterol kepada VLDL dan IDL. Oleh enzim hepatik lipase (HL), LDL dan HDL yang mengandung banyak trigliserida dihidrolisis sehingga ukuran LDL dan HDL menjadi lebih kecil dan menjadi lebih atherogenik.

Sehingga disimpulkan resistensi insulin mempunyai peran penting terhadap terbentuknya "Small dense $L D L$ " yang sangat aterogenik. Small dense LDL ini lebih mudah menembus dinding pembuluh darah dan lebih mudah dioksidasi oleh radikal bebas. Komposisi small dense LDL yang berbeda dengan LDL biasa juga akan mengakibatkan respstor LDL tidak mengenali LDL lagi. LDL yang tidak dikenali oleh reseptornya akan diambil oleh macrofag yang selanjutnya akan terbentuk foam cell dan bila keadaan terus berlanjut akan timbul fibrous plak di dinding pembuluh darah sehingga timbulah ateroma dan terjadilah aterosklerosis (18).

\section{KESIMPULAN}

1. Untuk uji aktivitas LPL in vitro dibutuhkan enzim ang diisolasi dari plasma post heparin dengan kondisi optimum suhu $32^{\circ} \mathrm{C}$, pH 6.8 dan waktu inkubasi 15 menit .

2. Dengan kondisi optimum ini dapat dibedakan aktivitas LPL pada orang dengan DM tipe 2 dan kelompok normal.

3. Aktivitas LPL pada pasien DM tipe 2 lebih kecil bila dibandingkan dengan aktivitas LPL pada kelompok normal ( $P$ $<0.0001)$

4. Berdasarkan hasil elektroforesis nampak bahwa ketebalan pita protein pada sampel dengan DM tipe 2 lebih tebal dibandingkan dengan sampel normal.

\section{SARAN}

Untuk menerapkan metode ini sebagai alternatif pemeriksaaan gangguan lipid pada DM tipe 2 perlu dikaji lebih luas kasus DM tipe 2 dengan obesitas.

\section{DAFTAR KEPUSTAKAAN}

1. Feher, D. M., and Ricmond, W., Lipid and lipid disorders. Times Mirror Int. Pub. Limited. 1997: 17-18, 26.

2. Gotto, A. M., Illingworth, Thomson, G. R., Carlson, L. A., Clinician's Manual on Hyperlipidemia. Internatinal Atherosclerosis Society. 1993: $14-28$.

3. Bell, D.S.H., Diabetes Mellitus and Coronary Artery Disease. J. Cardiovascular Risk. 1997: 4: 83 -90

4. Dugi, K. A., Feuerstein, I. M., Hill, Suvimol, Shih, Joana, et. al, Lipoprotein Lipase (LPL) correlates positively and Herpatic lipase Inversely With Calcific Atherosclerosis in Homozygous Familial Hypercholesterolemia, American Heart Association, Inc. 1997. 
5. David, J.H., and Hazel, P., Analytical Biochemistry, $2^{\text {nd }}$ edition, Longman Limited, England. 1993: 261.

6. Lehninger, A. L., Dasar-dasar Biokimia, Jilid 1, Alih Bahasa: Thenawidjaja, Penerbit Erlangga, Jakarta. 1995: 9, 235 - 237, 242, 253, 255.

7. Sumner and Myrback, 195 In, Wharton D.C and R.E Casty. 1972.

8. Merkel, M., Weinstock, P.H., Shaul, T.C., Radner, H., Lipoprotein Lipase Expression Exclusively in Liver. J. Clin. Invest. September 1998: 102: 893-901.

9. Schomburg, D., Enzyme Handbook, Springer -Verlag, German. 1990: 4.

10. Lehninger, A. L., Dasar-dasar Biokimia, Jilid 1, Alih Bahasa: Thenawidjaja, Penerbit Erlangga, Jakarta. 1990: 237, $242,255$.

11. Dhawale, D. A., Monitoring Enzyme Conversion of Penicillin G in Aquaeous Solution, Hidustan Antibiotics Bulletin. 1983: 25, 37-41.

12. Kusnawijaya, K., Biokimia. Penerbit: Alumni. Bandung. 1983: 123, 125, 131.

13. Montgomery, Rex. Biokimia Jilid II terjemahan: M Ismiadi, Gadjah Mada University Press, Yogyakarta. 1993.

14. Tjokroprawiro, A., Dislipidemia pada Diabetes Mellitus. Simposium Nasional Diabetes dan Lipid. 1994: 243-253.

15. Howard, B. V., \& Howard, W. J., Dyslipidemia in Non Insulin -Dependent Diabetes Mellitus. Endocrin Review. 1994: 15: 205-213.

16. Jellesof, N. E., Feinglos, M., Granger, C. B., Callif, R. M., Outcome of Diabetic Patients Following acute Myocardic Infarction: a Review of the Major Trombotic Trials. J. Cardiovasc. Risk. 1997.

17. Marks, B. D., Mark, A. D., Smith, C. M., Biokimia Kedokteran Dasar, Alih Bahasa: Brahm U Pendit, EGC. 1996.

18. Baynes, J.W., And Thorpe, S.R., Role Of Oxidatif Stress in Diabetic Complication A New Perspective on an Old Paradigm. Diabetes. 1999.

19. Calles, Jorge, Escandon and Cipolla Marilyn, Diabetes and Endothelial Dysfunction: A Clinical Perspective. The Endocrin Society. 2001

20. Fox, P. F., Food Enzymology, Elsever Science Publisher LTD, England. 1991: 73 - 75.

21. Girindra, A., Biokimia I. Gramedia, Jakarta. 1988: 91 - 113.

22. Kusnawidjaja, K., Biokimia, Penerbit: Alumni; Bandung. 1983: 123 -125, 131.

23. Martin, D. W., Mayes, and V.W. Rodwel., Harper's Review Of Biochemistry, Large Medical Publications, Singapura. 1983: 62-67, $87-89,96$.

24. Miller, Z. M., and Litsky, W., Industrial Microbiology, Macgraw Hill, Canada. 1976: 188.

25. Mingrone, G., Henriksen, Finn, L., Greco, Aldo, V., Krogh, Lotte, N., et.al. Trigliceride-Induced Diabetes associated With Familial Lipoprotein Lipase Deficiency. Catholic University, Rome. 1999.

26. Muchtadi, D., Palupi, dan Astawan, M., Enzim Dalam Industri Pangan, Jendral Pendidikan Tinggi Pusat Antar Universitas Pangan dan Gizi IPB, Bogor. 1992: 31-37, 60 -67.

27. Pickup and Williams., Textbook Of Diabetes, Blackwall Science Ltd. 1997.

28. Poejiadi, A., Dasar-dasar Biokimia, UI-Press. 1994: $44-67$.

29. Rahayu, K., Isolasi dan Pengujian Aktivitas Enzim, PAU Pangan dan Gizi Universitas Gajahmada, Yogjakarta. 1982: 59.

30. Rhoads, G. G., Gulbrandsen, C. L., Kagan, A., Serum lipoproteins and coronary heart disease in a population study of Hawaii japanese men. N Engl Med. 1976: 294, 293 - 298.

31. Robyt and White, Biochemical Tehniques Theory and Practise, Brooks/Cole Publishing Company, California. 1989: 40 - 47.

32. Soeatmadji, D. W., Prinsip-prinsip endokrinologi. Kursus Endokrinologi Dasar. FK. Unibraw. 2001.

33. Soeatmadji, J. W., Aulani'Am, Arsana, P. M., Rudijanto, A., Aktivitas LPL dan Profil Lemak Darah Pada DM. Majalah Kedokteran Univ. Brawijaya. 1999: 15(2): $58-60$.

34. Soehartono, Enzim dan Bioteknologi, Bioteknologi-IPB, Bogor. 1989: 147 - 150.

35. Soemitro, S. B., Fatchiyah, Rahayu, S., Widyarti, S., Arumningtyas, E.L., Kursus Tehnik-tehnik Dasar analisis Protein dan DNA, Jurusan Biologi, F.MIPA. 1996: 35 - 48.

36. Sukmawati, I. R., Mekanisme dan aspek Laboratorium Komplikasi Diabetes Mellitus. Forum Diagnosticum. 1999: 5: 8 - 9.

37. Voet, D., and Voet, J., Biochemistry. Jhon Willey and Sons Inc., New York. 1990: 88 -96.

38. Widodo, M. A., Renin Angitensin Peran Fisiologis dan Pada Patomekanisme Penyakit Jantung Pembuluh Darah, Kursus Endokrinologi Dasar FK. Unibraw. 2001.

39. Wijaya, Andi, Pemeriksaan Laboratorium Untuk Diagnosis dan Pengelolaan Diabetes Mellitus Up Date, Prodia Diagnostic Educational Services. 1997.

40. Winarno, F.G., Enzim Pangan, Gramedia, Jakarta. 1996: 48 - 54.

41. Zubay, G., Biochemistry, 2nd ed., Macmillan Publishing Company, Singapore. 1989: 100-115. 
Hal.

\title{
PERBEDAAN BENTUK LUKISAN SIDIK JARI, RIDGE COUNT, PALMAR PATTERN DAN SUDUT A-T-D ANTARA ORANG TUA ANAK SUMBING DENGAN ORANG TUA ANAK NORMAL DI TIMOR TENGAH SELATAN, NUSA TENGGARA TIMUR
}

\author{
Vincentia Maria Iriane ${ }^{*}$, Pudjo Sanjoto**, Retno M. Loekito** \\ * Mahasiswa Fakultas Kedokteran Unibraw \\ ** Laboratorium Anatomi Fakultas Kedokteran Unibraw
}

\begin{abstract}
The skin and lip-palate are formed nearly at the same period. They might be influenced by the similar genetic factor and environment. The objective of this research is to find the difference of dermatoglyphi between cleft-lip children's parents and normal childern's parents. The research is an analytical observation. It takes 50 samples of cleft-lip children's parents and 50 samples of normal children's parents. Each sample is classified into two groups, that is, (25) fathers and (25) mothers. Finger pattern, ridge count, palmar patern and a-t-d angle are dermatoglyphi variables to be measured. He result shows that: (1) The relationship between father's dermatoglifi and cleft-lip children is stronger than that between mother's dermatoglifi and cleft-lif childern. (2) The percentage of whorl (W) pattern is higher in cleft-lip children's parents; ehile the percentage of ulnar loop (UL)pattern is higher in normal children's parents. (3) The ridge count of cleft-lip children's fathers is normally higher than that of normal children's fathers. (4) There is no difference found in palmar pattern between cleft-lip children'parents and normal children's parents. (5) A-t-d angle of the cleft lips children's fathers is bigger than that of normal children's fathers. (6) Cleft lips in South East Timor, East Nusa Tenggara is ancertrally inherited.
\end{abstract}

Key words: Dermatoglyphies, cleft lip patients parent

\section{ABSTRAK}

Pembentukan kulit dan bibir-palatum terjadi dalam rentang waktu yang relatif bersamaan. Keduanya mungkin dipengaruhi faktor genetik dan lingkungan yang sama. Penelitian ini bertujuan mencari perbedaan dermatoglifi antara orang tua anak sumbing dengan orang tua anak normal. Penelitian dilakukan secara observasional analitik. Sampel terdiri dari 50 orang tua anak sumbing dan 50 orang tua anak normal, yang masing-masing dikelompokkan lagi menjadi 2, yaitu 25 ayah dan $25 \mathrm{ibu}$. Variabel yang diukur adalah dermatoglifi, yang meliputi bentuk lukisan sidik jari, ridge count, palmar pattern dan sudut a-t-d. Hasil penelitian ini menunjukkan bahwa: (1) Hubungan dermatoglifi ayah dengan kejadian sumbing pada anak lebih kuat dibandingkan hubungan dermatoglifi ibu dengan kejadian sumbing pada anak. (2) Prosentase pola whorl (W) lebih besar pada orang tua anak sumbing; prosentase pola ulnar loop (UL) lebih besar pada orang tua anak normal. (3) Rata-rata ridge count pada ayah anak sumbing lebih besar dari ayah anak normal. (4) Tidak ada perbedaan palmar pattern antara orang tua anak sumbing dengan orang tua anak normal.(5) Sudut a-t-d pada ayah anak sumbing lebih tumpul daripada ayah anak normal. (6) Kejadian sumbing di Timor Tengah Selatan (TTS), Nusa Tenggara Timur (NTT) diwariskan secara familial.

Kata kunci: Sidik jari, orang tua anak sumbing

\section{PENDAHULUAN}

Pada kulit jari tangan, telapak tangan, jari kaki dan telapak kaki terdapat sulur-sulur yang menimbulkan pola gambaran tertentu yang disebut dermatoglifi $(1,2)$. Dermatoglifi tidak akan berubah seumur hidup (3). Antara satu orang terhadap yang lain bahkan antar jari pada seorangpun tidak mungkin ada yang sama persis.

Dermatoglifi mulai terbentuk pada awal bulan kedua perkembangan embrio dan telah terbentuk secara sempurna pada minggu ke-17. Pembentukan dermatoglifi ini ditentukan oleh faktor genetik dan lingkungan embrio $(4,5)$. Bibir dan palatum mulai terbentuk pada minggu ke-6 dan telah terbentuk secara sempurna pada minggu ke-11. Kegagalan fusi pada pembentukan bibirpalatum menyebabkan terbentuknya celah (cleft). Kelainan ini disebut dengan sumbing. Faktor yang menjadi penyebab kelainan bawaan ini adalah faktor genetik, lingkungan, atau keduannya (6).

Pembentukan kulit dan pembentukan bibir-palatum terjadi pada waktu yang relatif sama sehingga keduanya bisa saja dipengaruhi oleh faktor internal (genetik) dan eksternal (lingkungan) yang sama. Dan tidaklah menutup kemungkinan bahwa insiden sumbing yang terjadi pada anaknya disebabkan karena mutasi genetik yang terjadi pada orang tuanya atau bahkan 2 generasi di atasnya. Terjadinya mutasi genetik ini juga akan mempengaruhi dermatoglifi.

Tujuan dari penelitian ini adalah untuk mengetahui perbedaan dermatoglifi (bentuk lukisan sidik jari, ridge count, palmar pattern, besar sudut a-t-d) antara orang tua anak sumbing dengan orang tua anak normal.

\section{METODE DAN CARA PENELITIAN}

Penelitian ini dilaksanakan dalam rancang bangun penelitian observasional analitik. Populasi penelitian ini adalah orang tua anak sumbing dan orang tua anak normal di Timor Tengah Selatan (TTS), Nusa Tenggara Timur (NTT).

Dalam penelitian ini, sampel yang digunakan 50 orang tua anak sumbing (25 ayah dan 25 ibu). Data sekunder yang telah

Maj. Kedok. Unibraw Vol. XIX, No.2, Agustus 2003 
diperoleh dibagi menjadi 2 kelompok, yaitu data dermatoglifi orang tua anak sumbing dan data dermatoglifi orang tua anak normal.

Kemudian dengan menggunakan kaca pembesar dilakukan pengamatan lebih lanjut untuk mendapatkan 1) bentuk lukisan sidik jari pada tiap jari kedua tangan yang meliputi a) W (whorl) dimana lukisannya berupa sulur-sulur yang membentuk putaran atau kelokan spiral seperli gelung serta memiliki dua triradius (pertemuan 3 sulur), b) RL (radial loop) dimana lukisannya berupa sulur-sulur yang membentuk belokan atau lengkung tajam yang membuka ke tepi radial serta memiliki satu triradius, c) UL (ulnar loop) dimana lukisannya berupa sulur-sulur yang membentuk belokan atau lengkung tajam yang membuka ke tepi ulnar serta memiliki satu triradius, d) A (arch) dimana sulursulurnya membentuk garis melengkung menyerupai busur serta tidak memiliki triradius, 2) ridge count pada tiap jari kedua tangan, diperoleh dengan membuat garis antara triradius dan titik pusat terlebih dahulu kemudian dihitung garis-garis yang melintasinya, 3) ada atau tidak pola atau bentuk lukisan pada tiap area palmar (telapak tangan), 4) sudut a-t-d (sudut yang dibentuk antara garis yang ditarik dari triradius a ke triradius $t$ dengan garis yang ditarik dari triradius $t$ ke triradius $d$ ) diukur dengan menggunakan busur derajat.

Dari data dermatoglifi orang tua anak sumbing dan orang tua anak normal 1) dihitung frekuensi dan prosentase kemunculan W, RL, UL, A untuk tiap jari kemudian dianalisa dengan uji chisquare, 2) dihitung rata-rata (mean) dan standart deviasi dari hasil penghitungan ridge kemudian dianalisa dengan $T$-test, 3 ) dihitung prosentase ada dan tidak pola untuk tiap-tiap area interdigital, thenar, dan hypothenar kemudian dianalisa dengan uji chi-square, 4) dilakukan pengukuran besar sudut a-t-d, dihitung rata-rata (mean) dan standart deviasinya kemudian dianalisa dengan $T$ test.

\section{HASIL PENELITIAN}

Tabel 1. Hasil Analisa Bentuk Lukisan Sidik Jari antara Orang tua Anak Sumbing dengan Orang tua Anak Normal dengan Uji Chi-square

\begin{tabular}{|c|c|c|c|c|}
\hline \multirow{2}{*}{ Tangan } & Jari & $\begin{array}{c}\text { Orang tua } \\
\text { anak sumbing } \\
\text { dengan orang } \\
\text { tua anak } \\
\text { normal }\end{array}$ & $\begin{array}{c}\text { Ayah anak } \\
\text { sumbing } \\
\text { dengan ayah } \\
\text { anak normal }\end{array}$ & $\begin{array}{c}\text { ibu anak } \\
\text { sumbing } \\
\text { dengan ibu } \\
\text { anak normal }\end{array}$ \\
\hline Kiri+kanan & 10 jari & $19,952^{*}$ & $15,850^{*}$ & $12,124^{*}$ \\
K & 5 & 1,328 & 0,5 & 1,086 \\
I & 4 & 0 & 0,802 & 0,724 \\
R & 3 & 1,841 & 1,389 & 1,032 \\
I & 2 & 3,243 & 1,545 & 2,883 \\
K & 1 & $14,070^{*}$ & $7,657^{*}$ & $9,710^{*}$ \\
A & 1 & $12,298^{*}$ & $9,704^{*}$ & 4,971 \\
N & 2 & $9,454^{*}$ & $10,500^{*}$ & 2,468 \\
A & 3 & 2,064 & 0,72 & 2,845 \\
N & 4 & $4,167^{*}$ & 3,125 & 1,298 \\
& 5 & 0,060 & 0,925 & 2,380 \\
\hline
\end{tabular}

Keterangan: $5=$ jari kelingking

$4=$ jari manis

$3=$ jari tengah

$2=$ jari telunjuk $1=i b u$ jari

* terdapat perbedaan bermakna

Tabel 2. Hasil Analisa Ridge Count antara Orang tua Anak Sumbing dengan Orang tua Anak Normal dengan $T$ tes.

\begin{tabular}{|c|c|c|c|c|}
\hline \multirow{2}{*}{ Tangan } & Jari & $\begin{array}{c}\text { Orang tua anak } \\
\text { sumbing } \\
\text { dengan } \\
\text { orang tua anak } \\
\text { normal }\end{array}$ & $\begin{array}{c}\text { Ayah anak sumbing } \\
\text { dengan } \\
\text { ayah anak normal }\end{array}$ & $\begin{array}{c}\text { ibu anak sumbing } \\
\text { dengan } \\
\text { ibu anak normal }\end{array}$ \\
\hline Kiri+kanan & 10 jari & $4,246^{*}$ & $4,608^{*}$ & 1,135 \\
K & 5 & 0,918 & 0,952 & 0,319 \\
I & 4 & 0,725 & 1,207 & $-0,095$ \\
R & 3 & 0,841 & 1,122 & 0 \\
I & 2 & 0,624 & 1,325 & $-0,613$ \\
K & 1 & $2,767^{*}$ & 1,809 & 2,117 \\
A & 1 & $2,760 *$ & $2,906^{*}$ & 0,979 \\
N & 3 & $1,236^{*}$ & $2,111^{*}$ & $-0,389$ \\
A & 4 & 0,332 & 0,986 & $-0,595$ \\
N & 5 & $2,129^{*}$ & 1,527 & 1,463 \\
\hline
\end{tabular}

Keterangan: $5=$ jari kelingking

$$
\begin{aligned}
& 4=\text { jari manis } \\
& 3=\text { jari tengah } \\
& 2=\text { jari telunjuk } \\
& 1=\text { ibu jari } \\
& \text { * terdapat perbedaan bermakna }
\end{aligned}
$$

Tabel 3. Hasil Analisa Palmar Pattern antara Orang tua Anak Sumbing dengan Orang tua Anak Normal dengan Uji Chi-square.

\begin{tabular}{|l|l|c|c|c|}
\hline \multirow{2}{*}{ Area } & Tangan & $\begin{array}{c}\text { Orang tua anak } \\
\text { sumbing dengan } \\
\text { orang tua anak } \\
\text { normal }\end{array}$ & $\begin{array}{c}\text { Ayah anak } \\
\text { sumbing dengan } \\
\text { ayah anak normal }\end{array}$ & $\begin{array}{c}\text { ibu anak } \\
\text { sumbing } \\
\text { dengan } \\
\text { ibu anak normal }\end{array}$ \\
\hline Hypothenar & Kiri & 2,8368 & 3,191 & 0,354 \\
Thenar/ID1 & Kanan & 3,092 & 2,083 & 1,020 \\
ID2 & Kiri & 0,198 & 0,802 & 2,913 \\
Kanan & 0 & 0 & 0 \\
ID3 & Kiri & 0 & 0 & 0 \\
ID4 & Kanan & 2,040 & 1,020 & 1,020 \\
& Kiri & 0,088 & 0,595 & 0,222 \\
& Kanan & 1,168 & 3,125 & 0,103 \\
& Kiri & 0,190 & 0,095 & 0,095 \\
Kanan & 0,666 & 2 & 0,095 \\
\hline
\end{tabular}

Keterangan: ID1= Interdigital 1

ID2= Interdigital 2

ID3 = Interdigital 3

ID4= Interdigital 4 
Hal.

Tabel 4. Hasil Analisa Sudut A-t-d antara Orang tua Anak Sumbing dengan Orang tua Anak Normal dengan $T$ test.

\begin{tabular}{|l|c|c|c|}
\hline \multirow{2}{*}{ Tangan } & \multicolumn{3}{|c|}{$\mathrm{X}^{2}$} \\
\cline { 2 - 4 } & $\begin{array}{c}\text { Orang tua anak } \\
\text { sumbing dengan } \\
\text { orang tua anak } \\
\text { normal }\end{array}$ & $\begin{array}{c}\text { Ayah anak sumbing } \\
\text { dengan } \\
\text { ayah anak normal }\end{array}$ & $\begin{array}{c}\text { ibu anak sumbing } \\
\text { dengan } \\
\text { ibu anak normal }\end{array}$ \\
\hline Kiri & $3,227^{*}$ & $4,586^{*}$ & 0,434 \\
Kanan & 2,362 * & $3,542^{*}$ & $-0,143$ \\
\hline
\end{tabular}

Keterangan: * terdapat perbedaan bermakna

\section{PEMBAHASAN}

Berdasarkan literatur, aspek genetik sumbing yang sebenarnya masih diperdebatkan orang. Para ahli mengungkapkan pendapat yang berbeda-beda mengenai teori ini, antara lain pewarisan secara terangkai $X$ dan autosomal.

Dari hasil penelitian ternyata hubungan dermatoglifi dengan kejadian sumbing pada anak lebih kuat dibandingkan dengan hubungan dematoglifi ibu dengan kejadian sumbing pada anak. Hal ini tidak disebabkan karena autosom (bila diwariskan secara autosom maka kejadian sumbing akan disertai kelainan kongenital yang lain) maupun $X$-lingked recesif. Menurut teori $X$ lingked recesif terdapat tiga kemungkinan, yaitu:

Kemungkinan I:

\section{$X X$ Ibu normal}

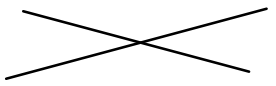

$x Y$ ayah sumbing

F1: $\quad X x$ carrier $X Y$ ônormal Xx q carrier $X Y$ ônormal

Kondisi ini tidak mungkin terjadi sebab ayah menderita sumbing.

Kemungkinan II:<smiles></smiles>

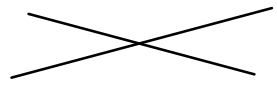

$x Y$ ayah sumbing

$\mathrm{F}$

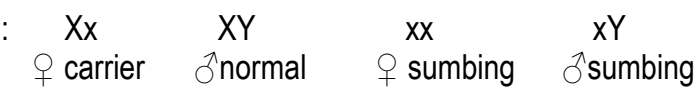

Kondisi ini tidak mungkin terjadi sebab ayah menderita sumbing

Kemungkinan III:

$$
\begin{gathered}
\text { Xx } \\
\text { Ibu carrier }
\end{gathered}
$$

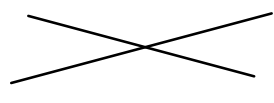

$X Y$ ayah normal
F1: $\quad X x$ $X Y$ $X X$ q carrier ônormal
$x Y$ $\partial^{\top}$ sumbing

Kondisi ini juga tidak mungkin terjadi pada daerah TTS, NTT karena F1 menunjukkan hanya anak laki-laki yang menderita sumbing sedangkan pada daerah ini jumlah laki-laki dan perempuan sumbing hampir sama banyaknya (peluang laki-laki sumbing 0,345 ; peluang perempuan sumbing 0,342 ).

Dengan gugurnya kedua teori di atas, maka kejadian sumbing di TTS, NTT ini kemungkinan disebabkan karena multifaktorial.

Dari hasil analisa bentuk lukisan sidik jari ternyata prosentase pola Whorl (W) lebih besar pada orang tua anak sumbing dan prosentase pola Ulnar Loop (UL) lebih besar pada orang tua anak normal.

Dari hasil analisa ridge count didapatkan rata-rata ridge count pada ayah anak sumbing yang lebih besar dari ayah anak normal, sedangkan pada ibu tidak selalu demikian. Dari hasil analisa palmar pattern ternyata tidak didapatkan perbedaan bermakna antara orang tua anak sumbing dengan orang tua anak normal.

Dari hasil analisa sudut a-t-d ternyata perbedaan bermakna terdapat pada ayah saja, sedangkan pada ibu tidak. Hal ini menunjukkan bahwa hubungan ayah-anak lebih kuat dari pada ibu-anak. Hal ini sesuai dengan Loekito (1992) dalam "Hubungan Labiopalatoschisis dengan Konsanguitas dan Beberapa Ukuran Kepala", dimana ternyata lebar bigonial ayah saja yang berbeda sedangkan ibu tidak (6). Hal ini menunjukkan bahwa korelasi bentuk wajah ayah-anak lebih kuat daripada ibuanak. Sudut a-t-d pada ayah anak sumbing lebih tumpul. Deshmukh (1979) berpendapat bahwa adanya variasi dermatoglifi yang tidak simetris antara tangan kiri dan kanan menunjukkan bahwa kejadian tersebut diwariskan secara familial (7). Apabila kejadian itu disebabkan oleh teratogen, maka pola dermatoglifi akan simetris antara tangan kiri dan kanan. Dari hasil penelitian didapatkan adanya variasi dermatoglifi yang tidak simetris antara tangan kiri dan kanan. Sehingga dapat dikatakan bahwa kejadian sumbing di TTS,NTT memang diwariskan secara familial.

Pada penelitian selanjutnya pengamatan pola sidik jari dapat dilakukan pada ibu jari kiri terlebih dahulu, dengan tidak mengabaikan jari yang lain. Karena perbedaan bermakna terutama didapatkan pada jari tersebut.

\section{KESIMPULAN}

Kesimpulan yang diperoleh dari penelitian ini yaitu:

1. Hubungan dermatoglifi ayah dengan kejadian sumbing pada anak lebih kuat dibandingkan hubungan dermatoglifi ibu dengan kejadian sumbing pada anak.

2. Prosentase pada whorl (W) lebih besar pada orang tua anak sumbing dan prosentase pola ulnar loop (UL) lebih besar pada orang tua anak normal.

3. Rata-rata ridge count pada ayah anak sumbing lebih besar dari ayah anak normal.

4. Tidak ada perbedaan palmar pattern antara orang tua sumbing dengan orang tua anak normal.

5. Sudut a-t-d pada ayah sumbing lebih tumpul daripada anak normal.

6. Kejadian sumbing di TTS, NTT diwariskan secara familial. 


\section{SARAN}

Saran yang dapat dibuat dari penelitian ini adalah:

1. Penelitian lebih lanjut tetang hubungan dermatoglifi orang tua dengan kejadian sumbing pada anak, sampel dapat difokuskan pada pola dermatoglifi ayah.

2. Melakukan penelitian tentang kerusakan kromosom pada anak sumbing.

3. Mencari kelainan lain yang manifes selain sumbing.
4. Melakukan penelitian lebih lanjut tentang faktor lingkungan apa saja di TTS, NTT yang dapat menyebabkan kejadian sumbing.

5. Melakukan penelitian serupa di daerah lain.

6. Melakukan peneitian serupa terhadap kelainan kongenital lainnya, misalnya sindroma down, kelainan jantung kongenital.

\section{DAFTAR PUSTAKA}

1. Cummins, H., Finger Prints, Palms and Soles: An Introduction to Dermatoglyphic. New York: Dover Publication Inc. 1961: 3-88.

2. Hidayati, R.S., et all. Penelitian Pola Triradius Garis Simian pada Telapak Tangan Anak-anak Penderita Sindroma Down di Sumber Asih Jakarta. Majalah Kedokteran Indonesia. 1980: 30(8): 202.

3. Karjadi, M., Sidik Jari Sistem Henry. Bogor: Politeia. 1976: 2-38.

4. Moore, K. L., The Developing Human, Clinically Oriented Embryology 4th Ed. Philadelphia: W.B. Sauders Company. 1982: 421-422.

5. Sadler, T. W., Langman's Medical Embryology $7^{\text {th }}$ Ed. Maryland: William and Wilkins Publisher. 1995: 368-369.

6. Loekito, R. M., Hubungan Labiopalatoschisis dengan Konsanguitas dan Beberapa Ukuran Kepala (disertasi). 1992: 9-54.

7. Deshmukh, R.N., et al. Dermatogliphics in Cleft Lip and Cleft Palate Anomaly: Fimilial and Teratogenic Groups. Indian J Med Res 70. 1979: 814-818.

8. Anonymous. Closing in On Clefting. 2002. Http://www.nidr.nih.gov/spectrum/NIDCR/1textsec6.htm. 


\title{
PENGARUH GAYA BERENANG (GAYA BEBAS DAN GAYA DADA) TERHADAP PERUBAHAN VOLUME OKSIGEN MAKSIMUM
}

\author{
Dennison ${ }^{*}$, Endang Sriwahyuni**, Viera Wardhani*** \\ * Mahasiswa Fakultas Kedokteran Unibraw \\ ${ }^{* *}$ Laboratorium Fisiologi Fakultas Kedokteran Unibraw \\ *** Laboratorium IKM-KP Fakultas Kedokteran Unibraw
}

\begin{abstract}
Swimming is frequently used to improve the individual physical endurance. Most of the studies have proved that swimming can improve the maximum oxygen volume effectively, but none of them compare the differences in the swimming styles. The study was aimed to analyse the differences of swimming styles in improving maximum oxygen volume, so it can be used as basis for physical training scheme. A pretest-posttest experimental design was conducted in two sample group (front crawl stroke group and breast stroke group) consists of six people in each group. The samples were selected based on questionaire to control the confounding variables, ie: sex, age, height, weight, training habit and health status (anemia, heart disease and respiratory distress). The training method were carried out in 12 session in 4 weeks ( 3 session per week) by increasing the swimming distance gradually. Each session arrangement was consists of warming up - training in short sets with rests - relaxation. The maximum oxygen volume was measured using Cooper method and the result was analyzed using independent sample t-test with SPSS 11. The result shows that there is a significant difference in maximum oxygen volume improvement ( $t=-4.718, C l 95 \%=l o w e r:-5.014$; upper: $-1.722, p=0.002)$ in which the result in breast stroke group has a higher improvement (mean: 6.313, sd: 1.378) compared to front crawl stroke group (mean: 3.203, sd: 1.941). This result may due to the glide position in breast stroke, the variation of measuring maximum oxygen volume and physiological variation of the swimmers
\end{abstract}

Key words: Swimming Style, Maximum Oxygen Volume

\section{ABSTRAK}

Latihan berenang banyak menjadi pilihan sebagai olahraga ketahanan yang di-tujukan untuk meningkatkan dan memelihara ketahanan fisik. Berbagai studi telah mengkaji efektifitas berenang dalam meningkatkan volume oksigen maksimum sebagai salah satu indikator ketahanan fisik. Namun belum ada studi yang secara spesifik mengkaji perbedaan gaya dalam latihan berenang terhadap peningkatan volume oksigen maksimum. Studi ini ditujukan untuk mengkaji pengaruh perbedaan gaya dalam latihan berenang terhadap peningkatan volume oksigen maksimum, sehingga dapat menjadi dasar dalam pilihan olah raga berenang. Penelitian dilakukan dengan pretest-postest experimental design pada kelompok latihan gaya bebas dan gaya dada dengan masingmasing kelompok terdiri dari enam orang coba. Pemilihan sampel orang coba dilakukan dengan seleksi menggunakan kuesioner untuk mengendalikan variabel pengganggu, yaitu jenis kelamin, usia, berat badan, tinggi badan, kebiasaan berolahraga dan gangguan kesehatan diantaranya anemia, penyakit jantung dan gangguan pernafasan. Latihan berenang dilakukan dalam 12 sesi latihan selama 4 minggu (3 sesi seminggu) dengan peningkatan jarak tempuh secara bertahap. Dalam setiap sesi latihan dilakukan dengan metode pemanasan - latihan dalam set pendek yang diselingi istirahat - relaksasi. Pengukuran volume oksigen maksimum dilakukan dengan metode Cooper, sedangkan analisis data dilakukan dengan uji independent sample t-test menggunakan SPSS 11. Hasil penelitian ini menunjukkan adanya perbedaan rata-rata peningkatan volume oksigen maksimum setelah latihan $(t=-4,718, \mathrm{Cl}$ 95\% = lower: $-5,014$; upper: $-1,722$ dan $p=0,002)$ dengan peningkatan lebih tinggi ditemukan pada kelompok gaya dada (mean: 6,313 , sd: 1,378) dibanding kelompok gaya bebas (mean: 3,203, sd: 1,941). Perbedaan tersebut dapat disebabkan oleh adanya fase meluncur pada gaya dada, variasi dari pengukuran volume oksigen maksimum dan variasi fisiologis orang coba.

Kata kunci: Gaya Berenang, Volume Oksigen Maksimum

\section{PENDAHULUAN}

Dalam olahraga, salah satu kunci untuk meraih kemenangan terletak pada ketahanan tubuh seorang atlet. Penelitian menunjukkan bahwa orang yang memiliki kapasitas konsumsi oksigen yang besar umumnya tampil lebih baik dalam pertandingan olahraga yang perlu ketahanan tubuh (1).

Volume oksigen maksimum $\left(\mathrm{VO}_{2}\right.$ maksimum) secara fungsional menunjukkan jumlah maksimum oksigen yang dapat diambil dari darah sirkulasi dan digunakan oleh jaringan-jaringan yang bekerja selama periode tertentu (2). $\mathrm{VO}_{2}$ maks ini dapat ditingkatkan dengan latihan ketahanan (3). Karena berenang merupakan salah satu dari olahraga ketahanan, maka latihan berenang akan dapat meningkatkan $\mathrm{VO}_{2}$ maksimum.

Berenang dapat dilakukan dalam beberapa gaya yang berbeda. Dua gaya berenang yang umum digunakan adalah gaya bebas dan gaya dada. Gaya bebas merupakan gaya yang termudah dan paling adekuat untuk melatih sistim sirkulasi dan respirasi serta menstimulasi volume konsumsi oksigen maksimum (4). Sedangkan gerakan dalam gaya dada dianggap sebagai 
gerakan istirahat. Gaya bebas merupakan gaya dengan gerakan yang ritmis pada kaki dengan kayuhan yang bergantian pada lengan sedangkan gaya dada memiliki gerakan simetris pada dua sisi tubuh, dengan pergantian gerak antara kaki dan lengan disertai fase meluncur (5).

Berbasis pada fakta teoritis perbedaan gaya dada dan gaya bebas, menarik untuk dikaji apakah terdapat pengaruh perbedaan gaya dalam program latihan berenang terhadap peningkatan $\mathrm{VO}_{2}$ maksimum. Tujuan dari penelitian ini adalah untuk mengetahui pengaruh perbedaan gaya berenang, antara gaya bebas dan gaya dada, terhadap perubahan $\mathrm{VO}_{2}$ maksimum. Diharapkan hasil dari penelitian ini dapat menjadi dasar dalam mengembangkan program latihan olahraga ketahanan bagi atlet serta masyarakat umum.

\section{MATERI DAN METODE}

Penelitian dilakukan dengan rancangan pretest-posttest experimental design dengan dua kelompok perlakuan yaitu gaya bebas dan gaya dada, dan pengukuran volume oksigen maksimum sebagai outcome. Dua belas orang subyek dipilih dengan kriteria: laki-laki yang berumur 21-25 tahun dengan berat badan $60-70 \mathrm{~kg}$ dan tinggi badan $165-175 \mathrm{~cm}$; bukan perenang terlatih dan frekuensi olahraga rutin maksimal 2 kali seminggu; tidak mengalami gangguan kesehatan berupa sakit jantung, gangguan pernafasan berat, anemia berat atau sering pingsan, atau cedera yang menyebabkan gangguan gerak menetap. Subyek penelitian diambil dari mahasiswa laki-laki yang tinggal di Malang, diseleksi dengan kuesioner. Persetujuan keikutsertaan dilakukan dengan penandatanganan lembar persetujuan yang tersedia.

Ke duabelas subyek secara random ditetapkan sebagai kelompok perlakuan I (gaya bebas dan kelompok perlakuan II (gaya dada). Perlakuan latihan berenang dan pengukuran outcome $\left(\mathrm{VO}_{2}\right.$ maksimum) diberikan dengan prosedur sebagai berikut:

1. Penelitian dimulai dengan pretest berupa pengukuran $\mathrm{VO}_{2}$ maksimum masing-masing orang coba. Pengukuran berupa lari dengan cara Cooper selama 12 menit. Jeda waktu untuk istirahat sebelum mulai latihan berenang selama maksimal 2-3 hari. $\mathrm{VO}_{2}$ maksimum sebelum latihan dimulai tidak akan mengalami perubahan yang berarti selama periode istirahat tersebut karena peningkatan $\mathrm{VO}_{2}$ maksimum hanya bisa diperoleh dari akumulasi latihan.

Besar $\mathrm{VO}_{2}$ maksimum ditentukan dengan perhitungan menurut cara Cooper :

$\mathrm{VO}_{2}=\{0,0225 \mathrm{X}$ jarak lari yang ditempuh dalam 12 menit (meter) $\}-11,3$

$\mathrm{VO}_{2}$ maksimum menggunakan satuan $\mathrm{ml} / \mathrm{kg} /$ menit (6).

2. Metode latihan berenang dilakukan sebagai berikut:

- Pemanasan selama 10 menit. Berupa berenang dengan kecepatan 60\%-70\% kecepatan maksimum menggunakan gaya yang telah ditentukan dalam kelompok masing-masing (3).

- Latihan :
- Kecepatan yang digunakan sebesar $80 \%-85 \%$ kecepatan maksimum.

- Waktu istirahat sebesar setengah dari waktu latihan dalam tiap set.

- Set yang telah ditentukan diulang sampai mencapai jarak tempuh total pada hari itu.

Pada pertemuan pertama, jarak yang harus ditempuh 300 meter (3).

- Relaksasi selama 10 menit. Berupa berenang dengan kecepatan 60\%-70\% kecepatan maksimum menggunakan gaya yang telah ditentukan dalam kelompok masing-masing (3).

Latihan ini dilakukan 3 kali seminggu, selama satu bulan atau 12 kali pertemuan. Pada latihan inti dilakukan penambahan jarak tempuh secara bertahap, yaitu sebesar 100 meter tiap 3 kali pertemuan.

3. Post test dilakukan maksimal 2 hari setelah latihan yang terakhir. Karena setelah 2 hari akan mulai terjadi penurunan dari $\mathrm{VO}_{2}$ maksimum orang coba (3).

4. Dicari selisih dari hasil pretest dan posttest tiap-tiap orang coba. Selanjutnya dari tiap kelompok dicari rata-rata selisih $\mathrm{VO}_{2}$ maksimum.

5. Rata-rata peningkatan $\mathrm{VO}_{2}$ maksimum dari kedua kelompok perlakuan diuji dengan uji beda rata-rata, yaitu $t$ test.

Uji statistika untuk membandingkan rata-rata $\mathrm{VO}_{2}$ maksimum dari dua kelompok menggunakan uji beda rata-rata dengan independent $t$ test. Penghitungan dan analisa data menggunakan program SPSS.

\section{HASIL PENELITIAN}

Volume oksigen maksimum diukur secara tidak langsung menggunakan metode lari cara Cooper. Tabel 3.1 menyajikan hasil pengukuran volume oksigen maksimum yang merupakan konversi dari hasil pengukuran jarak tempuh lari dengan menggunakan rumus Cooper.

Hasil tersebut menunjukkan adanya peningkatan $\mathrm{VO}_{2}$ maksimum dari hasil pretest ke posttest. Peningkatan terjadi pada tiap orang coba, baik dari kelompok gaya bebas maupun kelompok gaya dada. Bila dibandingkan antara kedua kelompok terdapat perbedaan dari rata-rata $\mathrm{VO}_{2}$ maksimum, hasil rata-rata yang lebih besar ada pada kelompok gaya dada.

Dari hasil penghitungan dengan t-test diperoleh $\mathrm{t}$ hitung sebesar $-4,718$. Dengan df 8 , tingkat kepercayaan $95 \%$, two tailed, didapatkan $t$ tabel sebesar 2,306. Berarti t hitung berada di luar area penerimaan Ho. Jadi Ho ditolak dan Ha diterima. Dengan demikian dapat disimpulkan dari analisa t-test tersebut bahwa: terdapat perbedaan dari peningkatan rata-rata volume oksigen maksimum pada kelompok dengan latihan gaya bebas dan gaya dada. 
Tabel 3.1 Hasil Pengukuran Volume Oksigen Maksimum dari Pretest dan Posttest

\begin{tabular}{|l|c|c|c|c|}
\hline Kelompok & Orang Coba & VO2 Max Pretest & VO2 Max Posttest & Selisih VO2 Max \\
\hline Gaya & 1 & 37.345 & 40.787 & 3.442 \\
Bebas & 2 & 22.421 & 24.423 & 2.002 \\
& 3 & 26.95 & 33.471 & 6.521 \\
& 4 & 20.88 & 25.022 & 4.142 \\
& 5 & 35.995 & 37.633 & 1.638 \\
& 6 & 31.135 & 32.607 & 1.472 \\
\hline & & & Mean & 3.203 \\
& & & Standar Deviasi & 1.941 \\
\hline \multirow{3}{*}{ Gaya } & 1 & 36.081 & & \\
Dada & 2 & 37.57 & 43.33 & 7.249 \\
& 3 & 32.625 & 38.65 & 4.41 \\
& 4 & 31.556 & 39.897 & 6.025 \\
& 5 & 30.28 & 36.708 & 8.341 \\
& 6 & 20.583 & 26.005 & 6.428 \\
& & & Mean & 5.422 \\
\hline
\end{tabular}

\section{PEMBAHASAN}

Dari hasil analisa t-test didapatkan kesimpulan bahwa terdapat perbedaan dari peningkatan rata-rata volume oksigen maksimum pada kelompok dengan latihan gaya bebas dan gaya dada, dengan rata-rata volume oksigen maksimum dari kelompok gaya dada lebih tinggi daripada kelompok gaya bebas. Hal ini berbeda dari teori yang menyebutkan bahwa gaya bebas merupakan gaya yang paling adekuat untuk mening-katkan volume oksigen maksimum (4).

Faktor penyebab yang mungkin adalah terdapatnya perbedaan dari kedua gaya, yaitu pada fase meluncur pada gaya dada. Seperti yang disebutkan dalam tinjauan pustaka, dalam gaya dada terdapat fase meluncur, yang bisa dianggap pula sebagai fase istirahat, karena pada saat itu tubuh terdorong ke depan begitu saja tanpa perlu gerakan tambahan. Fase meluncur ini tidak terdapat dalam gaya bebas (5).

Perbedaan ini bisa dianalogikan dengan teori bahwa berenang dengan set-set pendek dengan diselingi istirahat akan lebih efektif dalam meningkatkan volume ok-sigen maksimum. Adanya istirahat di sela latihan akan memberi hasil yang lebih baik karena kelelahan diperlambat. Bila fase meluncur dalam gaya dada diasumsikan sebagai fase istirahat, maka dapat diartikan bahwa dalam gaya dada terdapat waktu istirahat ekstra, di mana dalam gaya bebas tidak didapatkan. Dilihat dari sudut pandang demikian, maka penggunaan gaya dada akan lebih memperlambat kelelahan dibandingkan gaya bebas, dan pada akhirnya akan menghasilkan peningkatan volume oksi-gen maksimum yang lebih tinggi (3).

\section{KESIMPULAN DAN SARAN}

Hasil penelitian menunjukkan bahwa perbedaan gaya berenang (gaya bebas dan gaya dada) mempunyai pengaruh dalam rata-rata peningkatan volume oksigen maksimum, dimana latihan dengan gaya dada mempunyai rata-rata peningkatan lebih tinggi dibanding latihan berenang dengan gaya bebas. Perbedaan tersebut disebabkan adanya fase meluncur dalam gaya dada yang dapat diidentikkan sebagai fase istirahat dalam satu set latihan. Adanya fase istirahat dapat memberikan peningkatan volume oksigen maksimum yang lebih tingggi dibandingkan dengan set latihan tanpa fase istirahat.

Secara keseluruhan hasil penelitian juga menunjukkan bahwa program latihan berenang baik gaya bebas maupun gaya dada dapat meningkatkan volume oksigen maksimum. Sehingga program tersebut dapat dijadikan program latihan ketahanan baik bagi atlet renang, pelatih renang, maupun perenang biasa.

Adanya perbedaan hasil penelitian ini dengan teori sebelumnya mendukung perlunya penelitian lebih lanjut dengan kontrol yang lebih ketat pada karakteristik orang coba. Hal ini perlu dilakukan supaya faktor pengganggu makin sedikit dan hasil penelitian menjadi lebih valid.

\section{DAFTAR KEPUSTAKAAN}

1. Costill, D.L., Adaptation in Skeletal Muscle During Training for Sprint and Endurance Swimming; Swimming Medicine IV (Eds.) Baltimore. University Park Press. 1978: 233-248.

2. Kimura, Y., Simulated Swimming: A Useful Tool For Evaluating the VO2 Max in Laboratory. British Journal of Sport Medicine. 1990.

3. Maglischo, E.W., Swimming Faster. Chico. Mayfield Publishing Company. 1982: 270-313.

4. Trummer, P., 2001. (http//www.swimefsl.ritanet.net/coach201.htm, diakses 22 Mei 2002)

5. Parker, J., Wiping Your Swimmers Out. Swimming Technique. 1990 


\title{
FAKTOR-FAKTOR YANG MELATARBELAKANGI INTENSITAS TERAPI PERILAKU AUTISME METODE ABA (APPLIED BEHAVIOR ANALYSIS) PADA ANAK AUTIS DI RUMAH
}

\author{
Aisyah, Asmika, Nanik Setijowati \\ Fakultas Kedokteran Unibraw
}

\begin{abstract}
The Autism children in Indonesia had increased drastically every year. From HOPA's (Himpunan Orang tua Peduli Autisme) data, in Malang and surrounding area, there were 12 autism children in 2001, 98 children ini 2002 and increased to 120 children in June 2003. Major behavioral therapy centers in Indonesian are using ABA method for autism's therapy. The 3 intensity of ABA methode needs to apply at leas 40 hours a week to get on optimal result. However, in "A- PLUS " Dharma Wanita Autistic Behavioral Therapy Center, the intensity of ABA methode didn't achieve the target. Thus the lack of time should be substitute by applying at home. The objective of the study is to observe the factors that influence the intensity of autistic behavioral therapy with ABA methode to the autismchildren a their home. This research is descriptive observational with cross sectional study using questionaire as instrument. The Study has been done 17 parents with autism children whom received behavioral therapy in "A-PLUS "Dharma Wanita Autistic Behavioral Therapy Center Kota Malang. It was held from June until August 2003 using quota sapling technique. The result of the intensity of ABA methode on autistic children at home is sufficient (47\%). The respondent's knowledge about autism and the treatment are good (59\%). The father's occupations are merchant (70\%) while the mother's are housewives (58\%). The incomes of the parets are more than 2 million rupiah monthly (59\%). Duration of respondent's dialy activity is more then six hours (53\%). Respondents families are extended family (65\%) with two children (65\%). Almost all respondent (82\%) are not participating in any autism organization in Malng. The study hows that the intensity of autism behavioral therapy with ABA method to autism children at home is mostly sufficient because the respondent's knowledge about autism and the treatment are good.
\end{abstract}

Key words: Autism, Autistic Behavioral Therapy, and ABA Method

\begin{abstract}
ABSTRAK
Jumlah anak penyandang autisme di Indonesia mengalami peningkatan yang drastis dari tahun ke tahun. Di Malang dan sekitarnya, dari data Himpunan Orang tua Peduli Autisme (HOPA) tahun 2001 tercatat 12 anak penyandang autisme, tahun 2002 terdaftar 98 anak dan pada bulan Juni 2003 tercatat 120 anak autis. Di Indonesia, terapi perilaku yang banyak dijalankan oleh pusat-pusat terapi untuk anak autis adalah ABA. Intensitas terapi perilaku ini mensyaratkan minimal 40 jam seminggu untuk mencapai hasil yang optimal. Tetapi intensitas terapi perilaku di Pusat Terapi Autisme 'A-Plus' Malang tidak mencapai angka tersebut, sehingga kekurangan dari jumlah waktu terapi bagi anak autis harus diberikan di rumah. Penelitian ini dimaksudkan untuk memperoleh gambaran tentang faktor-faktor yang melatarbelakangi intensitas terapi perilaku autisme metode ABA pada anak autis di rumah. Penelitian ini bersifat deskriptif observasional melalui pendekatan cross sectional study dengan instrumen penelitian berupa kuisioner. Responden sebanyak 17 orang tua dari anak penyandang autisme yang diterapi di pusat terapi autisme 'A-Plus' Dharma Wanita PUNM Kotamadya Malang mulai Juli 2003 sampai dengan Agustus 2003 yang diperoleh dengan teknik quota sampling. Didapatkan hasil intensitas terapi perilaku autisme metode ABA pada anak autis di rumah adalah cukup (47\%). Tingkat pengetahuan responden tentang autisme dan penanganannya baik (59\%). Pekerjaan ayah wiraswasta (70\%) dan ibu tidak bekerja (58\%). Penghasilan orang tua lebih dari 2 juta rupiah perbulan (59\%). Durasi aktivitas responden di luar rumah lebih dari 6 jam per hari (53\%). Struktur keluarga responden adalah extended family (65\%) dengan jumlah anak 2 orang (65\%). Hampir seluruh responden (82\%) tidak ikut serta dalam keanggotaan organisasi khusus autisme di Malang. Dari penelitian diperoleh gambaran bahwa intensitas terapi perilaku autisme metode $A B A$ pada anak autis di rumah sebagian besar cukup baik karena didukung oleh tingkat pengetahuan yang dimiliki responden tentang autisme dan penanganannya baik.
\end{abstract}

Kata kunci: Autisme, Terapi Perilaku Autisme, Metode ABA.

\section{PENDAHULUAN}

Anak harus tumbuh dan berkembang menjadi manusia dewasa yang baik yang bisa mengurus dirinya sendiri dan tidak bergantung atau menimbulkan masalah pada orang lain, pada keluarga atau masyarakatnya (1).

Tetapi suatu kenyataan yang tidak dapat dipungkiri bahwa adanya sejumlah anak yang memperlihatkan perilaku tidak wajar, bertingkah laku tidak sesuai dengan norma, baik norma budaya maupun norma sosial yang berlaku dalam lingkungan dimana anak berada, sehingga tingkah laku mereka ini biasanya lebih dirasakan oleh lingkungannya dari pada oleh anak sendiri (2).

Pembahasan mengenai anak dengan Gangguan Perkembangan atau Gangguan Pervasif (Autisme, Asperger Syndrome, Rett Syndrome, dII) akhir-akhir ini sudah semakin informatif (3). 
Autisme bukanlah penyakit menular, namun suatu gangguan perkembangan yang luas yang terjadi pada anak. Gejala muncul sebelum usia tiga tahun. Perkembangan yang terganggu adalah bidang komunikasi, interaksi sosial dan perilaku (4).

Pada tahun 1987 disebutkan 1: 5000 anak menunjukkan gejala autisme, sepuluh tahun kemudian tercatat 1: 500 anak. Bahkan tiga tahun kemudian angka ini meningkat menjadi 1: 150 anak, dan tahun 2001 yang lalu sudah mencapai 1: 100 anak (5). Di Malang dan sekitarnya, tahun 2001 tercatat 12 anak penyandang autisme, tahun 2002 bulan Februari yang terdaftar 98 anak dan pada bulan Juni 2003 tercatat 120 anak autis (Himpunan Orang tua Peduli Autisme-HOPA).

Terapi-terapi dan model pendidikan bagi anak-anak dengan gangguan perkembangan khususnya autisme mulai mendapat perhatian khusus dari para ahli (3). Di Indonesia, terapi perilaku yang banyak dijalankan oleh pusat-pusat terapi untuk anak autis adalah ABA (Aplied Behavior Analysis) yang mulai dipraktekkan pada tahun 1997 (6).

Kurikulum ABA terdiri atas lebih dari 500 tugas individual yang perlu dikerjakan, dan terapi berlangsung sekitar 2 tahun secara intensif dengan 40 jam per minggu (6). Persyaratan ini sangat sulit dipenuhi oleh para orang tua karena apabila akan dilakukan di sekolah, mereka terbentur pada masalah biaya yang besar. Bila akan dilakukan di rumah, mereka sendiri tidak mempunyai waktu yang cukup, karena masih ada anak-anak yang lain atau karena mereka harus bekerja mencari nafkah (7).

Dari majalah Nakita edisi Februari 2002 diketahui bahwa rata-rata klinik khusus yang menangani autisme di beberapa tempat di Jakarta hanya memberikan terapi 10 jam dalam setiap minggunya. Sisanya dilakukan di rumah oleh orang tua atau terapis. Berdasarkan wawancara dengan Dra. Indrawati, MEd selaku pimpinan pusat terapi autisme 'A-Plus' sekaligus anggota HOPA (Himpunan Orang tua Peduli Autisme) di Malang mengatakan bahwa rata-rata terapi yang diberikan untuk anak autis di tempat tersebut adalah 5 kali per minggu dimana setiap sesi berlangsung selama 2 jam. Jadi rata-rata 10 jam perminggunya. Dan yang lebih penting lagi, walaupun anak-anak autis sudah diterapi di pusat/tempat terapi, di rumah pun tetap dilatih, mengingat bahwa waktu yang dihabiskan di rumah tentu lebih banyak (8).

Jadi, dari data tersebut diatas dapat dikatakan bahwa intensitas terapi di pusat terapi autisme 'A-Plus' Malang tidak mencapai angka 40 jam per minggunya, sehingga kekurangan dari jumlah waktu terapi bagi anak autis harus diberikan di rumah, disamping itu waktu yang dihabiskan oleh anak autis lebih banyak di rumah. Sehingga penelitian ini bertujuan ingin mengetahui mengenai faktor-faktor yang melatarbelakangi intensitas terapi perilaku metode ABA bagi anak autis di rumah.

\section{METODOLOGI}

Metode yang digunakan deskriptif observasional dengan pendekatan cross sectional study untuk memperoleh data mengenai faktor-faktor yang melatarbelakangi intensitas terapi perilaku autisme metode ABA pada anak autis di rumah. Sebagai Populasi adalah semua orang tua dari anak-anak penyandang autisme yang menjalani terapi di Pusat Terapi Autisme 'A- Plus' Dharma Wanita PUNM Kotamadya Malang. Sampel dalam penelitian ini adalah semua orang tua (ayah atau ibu) dari anak penyandang autisme yang diterapi di Pusat Terapi Autisme 'APlus' Dharma Wanita PUNM Kotamadya Malang yang diperoleh dengan teknik quota sampling. Lokasi penelitian dilakukan di Pusat Terapi Autisme 'A-Plus' Dharma Wanita PUNM Kotamadya Malang. Waktu penelitian dilakukan mulai bulan Juli sampai dengan Agustus 2003.Instrumen Penelitian kuesioner tertutup dan terbuka yang diberikan secara langsung kepada reponden.

1. Data variabel pengetahuan dan intensitas Terapi perilaku yang terkumpul dilakukan tabulasi, kemudian diberikan skor pada jawaban responden. Jawaban ini diberi skor 1 sampai 5. Diberi skor 0 bila responden tidak menjawab.

Untuk jawaban dari pertanyaan yang menanyakan tentang pendapat responden, dengan menggunakan skala Likert, pengolahannya menggunakan skoring dengan nilai:

$\mathrm{STS}=1 ; \mathrm{TS}=2 ; \mathrm{RR}=3 ; \mathrm{S}=4 ; \mathrm{SS}=5$

Keterangan:

STS = Sangat Tidak Setuju

TS = Tidak Setuju

$\mathrm{RR}=$ Ragu-ragu

$S \quad=$ Setuju

SS = Sangat Setuji

Untuk pertanyaan positif.

$\mathrm{STS}=5 ; \mathrm{TS}=4 ; \mathrm{RR}=3 ; \mathrm{S}=2 ; \mathrm{SS}=1$

Untuk pertanyaan negatif.

Selanjutnya dijumlahkan dan dibandingkan dengan skor tertinggi lalu dikalikan $100 \%$ dengan rumus:

$$
\mathrm{N}=\frac{\mathrm{Sp}}{\mathrm{Sm}} \times 100 \%
$$

Keterangan

$\mathrm{N}$ : Nilai yang didapat

Sp : Skor yang didapat

$\mathrm{Sm}$ : Skor tertinggi

Hasil pengolahan data berupa prosentase diinterpretasikan dengan kriteria kualitatif:

a. $76-100 \%=$ baik

b. $56-75 \%=$ cukup baik

c. $40-55 \%=$ kurang baik (9)

2. Data variabel aktivitas orang tua, struktur keluarga, dan organisasi khusus autisme yang terkumpul dilakukan tabulasi, kemudian dilakukan analisis data dengan distribusi frekuensi dan prosentase.

Nilai hasil prosentase kemudian diinterpretasikan dengan menggunakan skala:

$$
\begin{array}{ll}
0 \% & =\text { tidak satupun } \\
1-25 \% & =\text { sebagian kecil } \\
26-49 \% & =\text { hampir setengahnya } \\
50 \% & =\text { setengahnya } \\
51-75 \% & =\text { sebagian besar } \\
76-99 \% & =\text { hampir seluruhnya } \\
100 \% & =\text { seluruhnya }(9)
\end{array}
$$

Pengumpulan Data dilaksanakan dengan menggunakan teknik wawancara/kuisioner.

\section{HASIL PENELITIAN}


Hal.

Pengambilan sampel dilakukan dengan teknik quota sampling di Pusat Terapi Autisme 'A-Plus' Dharma Wanita PUMN Kotamadya Malang dengan instrumen penelitian berupa kuesioner. Jumlah sampel yang diharapkan dari lokasi penelitian tersebut adalah sebanyak 29 responden, tetapi hingga akhir waktu pengumpulan kuesioner yang telah ditentukan ternyata hanya 17 responden yang mengumpulkan kuesioner, sehingga oleh peneliti 13 orang lainnya dianggap tidak memenuhi kriteria inklusi penelitian.

Respondennya adalah para orang tua dari anak autis yang diterapi di pusat terapi autisme 'A-Plus' Malang dimana yang mengisi kuisioner terdiri dari ibu sebanyak 15 orang dan ayah 2 orang.

Hasil penelitian tentang faktor-faktor yang melatarbelakangi intensitas terapi perilaku autisme metode ABA pada anak autis di rumah adalah sebagai berikut:

Tabel 1. Distribusi Frekuensi Responden berdasarkan Karakteristik Responden

\begin{tabular}{|l|c|c|c|c|}
\hline Karakteristik responden & Ayah $\mathrm{n}=17)$ & & Ibu ( $\mathrm{n}=17)$ & \\
\hline & Frekuensi & $\%$ & Frekuensi & $\%$ \\
\hline Pendidikan & & & & \\
a. S.D. & 0 & 0 & 0 & 0 \\
b. SLTP & 4 & 0 & 0 & 0 \\
c. SLTA & 3 & 18 & 3 & 18 \\
d. Diploma & 10 & 58 & 11 & 18 \\
e.P.T & & & & \\
\hline Pekerjaan & 2 & 12 & 1 & 6 \\
a. P.N.S. & 0 & 0 & 1 & 6 \\
b. B.U.M.N. & 3 & 18 & 1 & 6 \\
c. Kary. Swasta & 12 & 70 & 4 & 24 \\
d. Wiraswasta & 0 & 0 & 10 & 58 \\
e. Tidak bekerja & \multicolumn{2}{|c|}{}
\end{tabular}

Dari data diatas diperoleh gambaran karakteristik orang tua anak penyandang autisme yang menjadi responden dalam penelitian ini, yaitu:

- Sebagian besar responden ayah (58\%) berpendidikan terakhir di perguruan tinggi. Sedangkan sebagian besar responden ibu (64\%) juga berpendidikan terakhir di perguruan tinggi.

- Sebagian besar responden ayah (70\%) memiliki usaha sendiri (wiraswasta) sebagai mata pencahariannya. Untuk responden ibu, sebagian besar (58\%) adalah ibu rumah tangga tetapi hampir setengah yang lain (42\%) adalah ibu-ibu yang bekerja.

Tabel 2. Distribusi Frekuensi Responden berdasarkan Tingkat Pengetahuan Autisme dan Penanganannya

\begin{tabular}{|c|c|c|}
\hline Kategori & Frekuensi & $\%$ \\
\hline Baik & 10 & 59 \\
Cukup & 2 & 12 \\
Kurang & 5 & 29 \\
\hline Jumlah & 17 & 100 \\
\hline
\end{tabular}

Dari tabel 2 diperoleh gambaran bahwa sebagian besar tingkat pengetahuan responden tentang autisme dan penanganannya adalah baik (59\%).
Tabel 3. Distribusi Frekuensi Responden Berdasarkan Pengetahuan tentang Metode ABA

\begin{tabular}{|c|c|c|}
\hline Pengetahuan tentang metode ABA & Frekuensi & $\%$ \\
\hline Tahu & 14 & 82 \\
Tidak tahu & 3 & 18 \\
\hline Jumlah & 17 & 100 \\
\hline
\end{tabular}

Dari tabel 3 diperoleh gambaran bahwa hampir seluruh responden (82\%) mengetahui tentang metode ABA (Applied Behaviour Analysis). Hanya sebagian kecil responden (18\%) belum mengetahui tentang metode $A B A$.

Tabel 4. Distribusi Frekuensi berdasarkan Penghasilan Keluarga per Bulan

\begin{tabular}{|l|c|c|}
\hline \multicolumn{1}{|c|}{ Penghasilan per bulan } & Frekuensi & $\%$ \\
\hline <Rp. 1.000.000,- & 0 & 0 \\
Rp. 1.000.000-2.000.000,- & 7 & 41 \\
>Rp. $2.000 .000,-$ & 10 & 59 \\
\hline & 17 & 100 \\
\hline
\end{tabular}

Dari tabel 4 diperoleh gambaran bahwa sebagian besar responden (59\%) memiliki penghasilan perbulan lebih dari $\mathrm{Rp}$. 2.000.000,- dan hampir setengah responden (41\%) berpenghasilan antara Rp.1.000.000-2.000.000,- per bulannya.

Tabel 5. Distribusi Frekuensi Responden berdasarkan Ratarata Jumlah Jam untuk Aktivitas Sehari-hari di Luar Rumah

\begin{tabular}{|c|c|c|}
\hline Jumlah jam per hari & Frekuensi & $\%$ \\
\hline$<2$ & 7 & 41 \\
$3-5$ & 1 & 6 \\
$>6$ & 9 & 53 \\
\hline Jumlah & 17 & 100 \\
\hline
\end{tabular}

Dari tabel 5 diketahui bahwa sebagian besar reponden $(53 \%)$ menghabiskan waktu rata-rata lebih dari 6 jam per harinya untuk aktivitas sehari-hari di luar rumah. Hampir setengah responden (41\%) yang menghabiskan kurang dari 2 jam per hari dan hanya 1 responden yang memakai 3-5 jam untuk aktivitas sehari-harinya.

Tabel 6. Distribusi Frekuensi berdasarkan Hubungan Kekerabatan yang Tinggal Serumah dengan Responden

\begin{tabular}{|l|c|c|}
\hline Hubungan kekerabatan & Frekuensi & $\%$ \\
\hline Nuclear family & 6 & 35 \\
Extended family & 11 & 65 \\
\hline \multicolumn{1}{|c|}{ Jumlah } & 17 & 100 \\
\hline
\end{tabular}

Dari tabel diatas diperoleh gambaran bahwa hubungan kekerabatan responden sebagian besar $(65 \%)$ adalah extended family.

Tabel 7. Distribusi Frekuensi berdasarkan Jumlah Anak Responden

\begin{tabular}{l|l|l} 
Jumlah anak & Frekuensi & $\%$
\end{tabular} 


\begin{tabular}{|c|c|c|}
\hline 1 & 2 & 12 \\
2 & 11 & 65 \\
$>2$ & 4 & 23 \\
\hline Jumlah & 17 & 100 \\
\hline
\end{tabular}

Dari tabel 7 diatas diperoleh gambaran bahwa sebagian besar responden (65\%) memiliki 2 anak.

Tabel 8. Distribusi Frekuensi berdasarkan Jumlah Jam Terapi Anak Autis per Minggu di Tempat Terapi

\begin{tabular}{|c|c|c|}
\hline Jumlah jam per minggu & Frekuensi & $\%$ \\
\hline$\leq 10$ & 10 & 59 \\
$>10$ & 7 & 41 \\
\hline Jumlah & 17 & 100 \\
\hline
\end{tabular}

Dari tabel 8 diketahui bahwa sebagian besar dari anak autis responden diterapi selama kurang dari atau sama dengan 10 jam per minggu (59\%) di tempat terapi.

Tabel 9. Distribusi Frekuensi berdasarkan Keberadaan Terapis di Rumah

\begin{tabular}{|c|c|c|}
\hline Keberadaan terapis & Frekuensi & $\%$ \\
\hline Ada & 3 & 18 \\
Tidak ada & 14 & 82 \\
\hline Jumlah & 17 & 100 \\
\hline
\end{tabular}

Dari tabel diatas dapat diketahui bahwa hampir seluruh responden (82\%) tidak mendatangkan terapis ke rumah. Hanya sebagian kecil responden (18\%) yang memanggil terapis untuk melatih anak autis di rumah.

Tabel 10.Distribusi Frekuensi berdasarkan Keberadaan Terapis Memberikan Latihan di Rumah dalam Jam per Minggu

\begin{tabular}{|c|c|c|}
\hline Jumlah jam per minggu & Frekuensi & $\%$ \\
\hline$<4$ & 1 & 33 \\
$5-6$ & 2 & 67 \\
\hline Jumlah & 3 & 100 \\
\hline
\end{tabular}

Tabel diatas menunjukkan bahwa dari 3 responden yang mendatangkan terapis ke rumah, 2 diantaranya menyatakan bahwa jumlah jam terapi yang diberikan oleh terapis berkisar 5-6 jam per minggunya dan responden yang lain hanya memberikan kurang dari 4 jam waktu bagi terapis untuk melatih anak autis di rumah.

Tabel 11. Distribusi Frekuensi berdasarkan Pendamping Anak Autis di Rumah Setiap Harinya

\begin{tabular}{|l|c|c|}
\hline \multicolumn{1}{|c|}{ Pendamping } & Frekuensi & $\%$ \\
\hline Ayah & 1 & 6 \\
Ibu & 10 & 59 \\
Lain-lain* & 6 & 35 \\
$\begin{array}{l}\text { Ket*:anggota keluarga yang lain, suster/baby } \\
\text { sister, pembantu. }\end{array}$ & & \\
\hline \multicolumn{1}{|c|}{ Jumlah } & 17 & 100 \\
\hline
\end{tabular}

Dari tabel diatas dapat dilihat bahwa sebagian besar responden (59\%) yang mendampingi anak autis di rumah setiap harinya adalah ibu.
Tabel 12.Distribusi Frekuensi berdasarkan Intensitas Terapi Perilaku Autisme di Rumah

\begin{tabular}{|c|c|c|}
\hline Kategori & Frekuensi & $\%$ \\
\hline Baik & 2 & 12 \\
Cukup & 8 & 47 \\
Kurang & 7 & 41 \\
\hline Jumlah & 17 & 100 \\
\hline
\end{tabular}

Tabel diatas menunjukkan bahwa hanya sebagian kecil responden (12\%) yang melakukan intensitas latihan di rumah dengan baik. Hampir setengah responden menerapkan intensitas latihan dengan kategori cukup (47\%) dan kurang (41\%).

Tabel 13. Distribusi Frekuensi Jumlah Jam per Hari berdasarkan Materi Latihan yang Diberikan Pendamping pada Anak autis di Rumah

\begin{tabular}{|c|c|c|c|c|c|c|}
\hline \multirow{2}{*}{$\begin{array}{c}\text { Jjam/hari } \\
\text { materi } \\
\text { latihan }\end{array}$} & \multicolumn{2}{|c|}{$\leq 4$} & \multicolumn{2}{c|}{$>4$} & \multicolumn{2}{c|}{ Jumlah } \\
\cline { 2 - 7 } & Frek & $\%$ & Frek & $\%$ & Frek & $\%$ \\
\hline Baik & 0 & 0 & 2 & 12 & 2 & 12 \\
\hline Cukup & 2 & 12 & 6 & 35 & 8 & 47 \\
\hline Kurang & 2 & 12 & 5 & 29 & 7 & 41 \\
\hline Jumlah & 4 & 24 & 13 & 76 & 17 & 100 \\
\hline
\end{tabular}

Dari tabel diatas diperoleh gambaran bahwa hanya sebagian kecil responden (12\%) yang menerapkan latihan di rumah dengan kategori baik kepada anak autis. Hampir setengah responden menjawab bahwa mereka menerapkan latihan dengan kategori cukup (47\%).

Sedangkan untuk jumlah jam pendamping, hampir seluruh responden (76\%) mengatakan bahwa mereka mendampingi anak di rumah lebih dari 4 jam.

Tabel 14. Distribusi Frekuensi berdasarkan Keikutsertaan Responden dalam Organisasi Khusus Autisme

\begin{tabular}{|c|c|c|}
\hline Ikut serta & Frekuensi & $\%$ \\
\hline Ya & 3 & 18 \\
Tidak & 14 & 82 \\
\hline Jumlah & 17 & 100 \\
\hline
\end{tabular}

Dari tabel 14 diketahui bahwa hampir seluruh responden (82\%) tidak ikut serta dalam suatu keanggotaan dari perkumpulan orang tua anak penyandang autisme. Hanya sebagian kecil responden (18\%) mengaku ikut dalam keanggotaan tersebut.

\section{PEMBAHASAN}

Gambaran Karakteristik Responden. Dari tabel 1 diperoleh gambaran bahwa sebagian besar responden memiliki tingkat pendidikan yang tinggi yaitu lulusan perguruan tinggi (ayah $=58 \%$, ibu=64\%). Hal ini berarti tidak sulit bagi responden untuk mencari informasi tentang autisme dan penanganannya (3).

Seluruh ayah dalam penelitian ini bekerja dengan bidang pekerjaan sebagian besar (70\%) adalah wiraswasta. Hal ini tentunya akan mengurangi waktu interaksi mereka dengan anak autis di rumah. Sehingga dituntut waktu lebih banyak dari ibu 
untuk mendampingi anak di rumah (7) Sebagian besar ibu dalam penelitan ini adalah ibu rumah tangga (58\%). Bahkan ada diantara mereka yang meninggalkan pekerjaanya karena anak autis perlu mendapat perhatian khusus (10). Sehingga mereka diharapkan dapat menyediakan waktu untuk mendampingi anak di rumah (7).

Gambaran Tingkat Pengetahuan Responden tentang Autisme dan Penanganannya. Dari tabel 2 diketahui bahwa tingkat pengetahuan responden tentang autisme dan penanganannya sebagian besar adalah baik (59\%). Hal ini tentunya akan memudahkan responden untuk mencari dan memahami informasi tentang autisme dan akan cukup terbuka tehadap perkembangan yang ada. Hal ini bisa berdampak sampai sebesar $80 \%$ pada kemajuan terapi anak (3).

Hampir seluruh responden (82\%) mengetahui tentang metode $A B A$ yang diterapkan kepada anak mereka di tempat terapi autisme 'A-Plus' Malang. Dan hampir seluruhnya juga mengetahui bahwa yang menunjang keberhasilan terapi autisme dangan metode ABA adalah jika dilakukan secara intensif di tempat terapi dan di rumah. Akan tetapi setengah dari responden juga beranggapan bahwa penanganan oleh banyak ahli yang profesional juga termasuk penunjang keberhasilan dalam metode ABA. Hal ini kurang tepat oleh karena penunjang keberhasilan dalam metode $A B A$ yaitu pelaksanaan yang intensif, optimal dan pada usia dini (6). Kemitraan orang tua dengan para ahli (psikiater, psikolog, orthopaedagog) hanya merupakan program yang dapat membantu optimalitas penerapan intervensi pada anak autis (11).

Gambaran Penghasilan Keluarga Responden. Sebagian besar responden memiliki penghasilan keluarga lebih dari 2 juta rupiah per bulannya (59\%). Hal ini tentu akan memberi kesempatan untuk mendapatkan penanganan sebaik mungkin bagi anak autis. Walaupun sebagian besar pendapatan keluarga responden lebih dari 2 juta per bulannya, dalam beberapa penelitian, para orang tua merasakan beban yang berat dalam membiayai pendidikan khusus, baik di tempat terapi/ sekolah maupun di rumah. Hal ini tampaknya dipengaruhi oleh makin berkembangnya informasi tentang cara-cara penanganan gangguan autis sehingga orang tua cenderung ingin mengikuti lebih banyak cara untuk 'menyembuhkan' anaknya (7).

Gambaran Aktivitas Sehari-hari Responden. Sebagian besar responden (53\%) yang dalam hal ini adalah ibu dari anak autis menghabiskan waktu lebih dari 6 jam perharinya untuk aktivitas sehari-hari di luar rumah. Ini bisa disebabkan karena hampir setengah responden ibu adalah wanita yang bekerja. Hal ini akan membatasi waktu interaksi antara sang ibu dengan anak di rumah $(7,10)$.

Gambaran Struktur Keluarga Responden. Dari tabel 6 diketahui bahwa hubungan kekerabatan yang tinggal serumah dengan anak autis adalah extended family (65\%). Menurut Wardhani, besaran anggota keluarga turut mempengaruhi pola penanganan anak dengan problematika autisme (11). Didalam extended family akan dijumpai anggota keluarga lain yang turut tinggal serumah dengan anak autis. Orang serumah yang seringkali menjadi penghalang adalah nenek dari anak tersebut. Meskipun banyak juga dijumpai para nenek yang justru ikut mendorong dan memberikan semangat untuk para orang tua anak agar segera menerapi anaknya dengan intensif. Para nenek yang menjadi penghalang biasanya adalah para nenek dominan yang sulit memahami tentang kelainan perilaku ini. Mereka menganggapnya hanya sebagai kenakalan biasa saja. Kelambatan bicara bukanlah hal aneh bagi mereka, oleh karena banyak anak mereka yang mengalami kelambatan bicara. Tapi orang lain yang serumah juga perlu diwaspadai dan kalau perlu juga diberi informasi yang cukup tentang kelainan ini (7).

Dari tabel 7 diketahui bahwa hampir seluruh responden $(88 \%)$ memiliki anak lebih dari 1 orang. Hal ini akan mempengaruhi besarnya perhatian yang diberikan oleh orang tua kepada anak autis maupun anggaran dana keluarga yang harus dikeluarkan untuk mencapai kesembuhan anak autis itu sendiri. Semakin banyak jumlah anak maka perhatian orang tua harus terbagi-bagi kepada seluruh anak tersebut. Sedangkan anggaran dana keluarga untuk anak yang lebih dari 1 orang akan lebih besar daripada keluarga dengan 1 anak (3).

Gambaran Intensitas Terapi Perilaku Autisme di Tempat Terapi. Sebagian besar dari responden (59\%) menerapi anak autis di tempat terapi kurang dari atau sama dengan 10 jam per minggu. Hal ini menunjukkan bahwa intensitas terapi perilaku di tempat terapi tidak mencapai angka 40 jam seminggu. Sehingga kekurangan jam tersebut harus dipenuhi di rumah.

Tetapi pada realitanya banyak orang tua anak dengan kebutuhan khusus seperti autisme menyerahkan (penanganan) anaknya "pasrah penuh" kepada institusi pusat terapi atau sekolah khusus. Mereka tidak mau tahu lagi dengan urusan pendidikan anaknya, cukup menyediakan biaya dan sarananya saja. Hal ini akan sangat merugikan dan sangat menghambat kemajuan terapi (7)

Gambaran Intensitas Terapi Perilaku Autisme di Rumah. Hampir seluruh responden (82\%) tidak mendatangkan terapis untuk menerapi anak di rumah. Hanya sebagian kecil saja $(18 \%)$ yang mendatangkan terapis ke rumah, itupun dengan intensitas terapi yang kurang dari 30 jam tiap minggunya. Hal ini bisa dimaklumi oleh karena biasanya kebutuhan dana untuk terapi di rumah jauh melebihi dari terapi di sekolah khusus. Terapis lepas biasanya menetapkan biaya terapi per jam dan mereka juga menuntut biaya transportasi. Kelangkaan terapis yang handal masih sulit didapat, sehingga mereka menetapkan harga yang tinggi (7).

Sebagian besar responden menyebutkan bahwa yang mendampingi anak autis di rumah setiap harinya adalah ibu $(59 \%)$. Karena memang seharusnya para orang tua terutama para ibu menyediakan waktu, pikiran dan tenaga untuk melakukan terapi sendiri bagi anaknya. Hal ini akan sangat mendukung terapi bagi anak autis jika para ibu mengerti teori tentang autisme dan metode ABA serta cukup terampil dalam berinteraktif dengan anak. Dan disiplin dalam metode $A B A$ juga harus mampu dilakukan oleh orang yang yang bersinggungan dengan anak baik sebagai terapis ataupun hanya sebagai anggota keluarga (7).

Mayoritas responden menerapkan intensitas terapi perilaku dengan kategori cukup. Hanya sebagian kecil responden yang menerapkan intensitas terapi perilaku autisme di rumah dengan kategori baik. Hal ini dapat disebabkan oleh ketidakpahaman responden ataupun pendamping anak tentang materi apa yang harus diberikan kepada anak autis dan bagaimana kemampuan anak dalam menyerap materi yang 
diajarkan, selain kurang terampilnya responden ataupun pendamping dalam berinteraktif dengan anak (7). Hal ini didukung dengan bukti dari tabel 13 yang menunjukkan bahwa hanya $12 \%$ responden yang memiliki kategori materi latihan baik. Jadi walaupun para orang tua terutama ibu mendampingi anak di rumah dalam jangka waktu cukup lama (lebih dari 4 jam per hari) tetapi mereka tidak menerapkan materi latihan yang sesuai konsep terapi perilaku metode ABA dengan baik. Sebab bukan hanya jumlah jam yang disediakan untuk intervensi yang penting, tetapi penting juga apa yang dikerjakan selama waktu tersebut. Seorang terapis atau orang tua yang terampil mungkin dapat menghasilkan lebih banyak kemajuan pada anak dalam 10 jam dibanding individu yang kurang terampil yang dikerjakan dalam 30 waktu jam dengan anak yang sama (6).

Gambaran Keikutsertaan Responden dalam Organisasi Khusus Autisme. Tabel 14 memberi gambaran bahwa hampir seluruh responden (82\%) tidak ikut serta dalam suatu keanggotaan organisasi khusus autisme. Sebagian diantara mereka menyebutkan bahwa alasan ketidakikutsertaan mereka oleh karena di Malang organisasi seperti itu tidak ada. Padahal berdasarkan wawancara dengan Dra. Indrawati, M.Ed selaku pimpinan pusat terapi autisme 'A-Plus' dan anggota HOPA, mengatakan bahwa sebetulnya organisasi semacam itu ada yaitu Himpunan Orang tua Peduli Autisme (HOPA). Jadi sebetulnya responden belum mengetahui keberadaan organisasi khusus autisme di Malang.

\section{KESIMPULAN :}

Gambaran bahwa intensitas terapi perilaku autisme metode ABA pada anak autis dirumah sebagian besar cukup baik hal ini didukung oleh tingkat pengetahuan yang dimiliki responden tentang autisme dan penanganannya baik.

\section{DAFTAR KEPUSTAKAAN}

1. Gunarsa, S., Teori Perkembangan Anak. Jakarta: BPK Gunung Mulia. 1980.

2. Staf Pengajar IImu Kesehatan Anak. Buku Kuliah IImu Kesehatan Anak. Jakarta: Info Medika. 1985.

3. Chandra, T., Membantu Orang tua dalam Menangani dan Mendidik Anak dengan Gangguan Perkembangan Pervasif. Spectrum Treatment and Education Center. (online), (http://www.spectrum-autism.com, diakses 19 Maret 2002).

4. Sutady, R., Autisme: Gangguan Perkembangan Pada Anak. Dibacakan di Simposium Autisme. Yayasan Autisme Indonesia. Jakarta. 1997.

5. Kurnasih, D., dan Koesworini E., Menangani Anak autis. Nakita edisi Februari. Jakarta: PT Gramedia. 2002.

6. Sutady, R., Seminar dan Pelatihan Autisme 2 Hari. Jakarta: Lembaga Intervensi Terapan Autisme. 2000.

7. Handoyo, Y., Autisma-Petunjuk Praktis Pedoman Materi untuk Mengajar Anak Normal, Autis dan Perilaku Lain. Jakarta: PT. Bhuana IImu Populer. 2003.

8. Indrawati, Hendarto, Y.E., Kiat Membimbing Anak Autis. Makalah disajikan dalam Seminar Mampersiapkan Anak Penyandang Autis Hidup Mandiri. Malang. 6 April 2003.

9. Roesmana, J., Siregar, U., Terapi Baru Autisme. Femina, no. 29/XXX 18-24 Juli, 2002: 91

10. Arikunto, Suharsini. Prosedur Penelitian Suatu Pendekatan Praktek. Jakarta: Rineka Cipta. 1998.

11. Kompas. 22 November 1999. Pengalaman Orang tua Memenangkan Anak Autis, (Online), (http:www.handoko.net/keluarga.org/autisme.shtml, diakses 31 Maret 2002).

12. Buku Saku Diagnosis Gangguan Jiwa rujukan Ringkas dari PPDGJ III. Dalam Maslim R (Ed.). Jakarta. 2001.

13. Yuniar, S., Gangguan Spektrum Autisme dan Kiat Menanggulanginya. Makalah dibacakan dalam Seminar Maempersiapakan Anak Penyandang Autisme Hidup Mandiri. Malang. 6 April 2003.

14. Diagnostik and Statistical Manual of Mental Disorders. American phychiatric Assosiation. Washington DC. 1994.

15. Sutady, R., Autisme?! Apakah itu?. Buletin Autisme. Yayasan Autisme Indonesia. Jakarta, 1999.

16. Anonymous. Mengenal Autisme. (Online), (htttp://www.iqeq.web.id/art/art0.5.shtml, diakses 14 Maret 2002)

17. Indrawati. Deteksi Dini Autisme. Pimpinan Pusat Terapi Autisme "A-Plus" Dharma Wanita PUNM Kotamadya Malang. Malang. 2000.

18. Anonymous. Keunikan Autisme. (Online) (http://www.puterakembara.org/sebab.shtml, diakses 9 Maret 2002)

19. Anonymous, Pendidikan Khusus Bagi Anak dengan Gangguan Perkembangan. Spectrum Treatment and Education Center. (Online), (http://www.spectrum-autism.com, diakses 19 Maret 2002)

20. Hurlock, Elizabeth, H., Perkembangan Anak. Jilid 2. Jakarta: Penerbit Erlangga. 1989.

21. Notoadmodjo, Soekidjo. Metodologi Penelitian Kesehatan. Jakarta: Rineka Cipta. 1993.

22. Ginanjar, A.S., Wardhani, E.R., Towards A Better Life for Autistic Individual. Makalah dibacakan dalam Konferensi Nasional Autisme I. Jakarta, 2-4 Juli 2003.

23. Machmud, Rander. Pelaksanaan Holistic Autisme. Makalah dibacakan dalam Kongres Nasional Autisme Indonesia Pertama. Pusat Informasi dan Penelitian FKUI. Jakarta, 3 Mei 2003.

24. Ahmadi, A., Psikologi Sosial. Jakarta: PT. Rineka Cipta. 1991. 


\title{
PAKAIAN SEBAGAI PELINDUNG SURYA
}

\author{
Tantari SHW \\ Laboratorium IImu Kesehatan Kulit dan Kelamin Fakultas Kedokteran \\ Universitas Brawijaya, Malang
}

\begin{abstract}
Although sunlight is of much benefit for live, it has an adverse effects on human skin. The effects of sunlight can be controlled by using protective cream or reducing the exposure to sunlight. Appropiate design clothes and correct protective factorsare part of efforts can prevent all spectrum of UV rays. The clothes's protective nature depend on it's fibre's struvture, colour, waterproof properties, as well as it's refine processes. Personal protection towards Ultraviolet radiation can be further supported by wearing a big cap, using an umbrella, being under a shade, using appropriate protective clothes and avoiding the sunlight between $10.00 \mathrm{am}$ until $04.00 \mathrm{pm}$. The above steps should be initiated at an children. In every country including Indonesia, there should be standarritation and regulation concering protective steps towards sunlight.
\end{abstract}

\begin{abstract}
ABSTRAK
Sinar surya selain banyak memberikan manfaat bagi kehidupan, juga memiliki berbagai efek yang merugikan kulit manusia. Paparan surya pada dasarnya dapat dikendallikan melalui perlindungan kulit atau meminimalkan paparan. Mengenakan pakaian dengan desain dan faktor pelindung yang tepat merupakan upaya yang dapat mencegah semua spektrum sinar UV. Daya perlindungan kain dipengaruhi oleh struktur serat, warna, basah tidaknya kain serta proses penyempurnaan kain tersebut. Perlindungan perorangan terhadap radiasi UV dapat ditunjang dengan mengenakan topi bertepi lebar, memakai payung, mencari tempat teduh, memakai tabir surya yang tepat dan menghindari paparan surya antara pukul 10.00 hingga pukul 16.00. Perilaku perlindungan surya yang benar seyogyanya dimulai sejak usia kanak-kanak. Disetiap negara termasuk Indonesia perlu dibuat standarisasi dan regulasi mengenai langkah-langkah perlindungan surya.
\end{abstract}

\section{PENDAHULUAN}

Sampai saat ini sinar matahari (sinar surya) menjadi satu-satunya sumber paparan energi dalam spektrum fotobiologi kulit manusia. Manfaat dari sinar surya dalam kehidupan makhluk di dunia telah banyak diketahui, yaitu memberikan energi untuk fotosintesis, penerangan alam dan kesehatan. Selain bermanfaat bagi kehidupan, terdapat banyak bukti yang menunjukkan bahwa sinar surya memiliki efek buruk terhadap kulit manusia. Secara umum efek tersebut dibagi menjadi dua yaitu: efek akut yang meliputi terbakar surya (sunburn) dan gosong kulit (suntan), serta efek kronis berupa gangguan pigmentasi, penuaan dini dan beberapa kanker kulit (1). Sekalipun promosi kesehatan meningkat dan manusia makin mengenal serta waspada terhadap efek buruk paparan sinar surya, namun paparan sinar surya ini tidak mudah dihindari. Hal ini diperburuk dengan adanya kecenderungan deplesi lapisan ozon yang berakibat meningkatnya radiasi sinar ultraviolet (UV) pada permukaan bumi.

Para pasien dan masyarakat sering bertanya pada dokter termasuk ahli dermatologi mengenai bagaimana agar tampak tetap terlihat muda, sehat dan terhindar dari risiko kanker kulit. Untuk itu tentunya diperlukan pengetahuan yang benar mengenai cara perlindungan terhadap paparan sinar surya.

Paparan sinar surya pada manusia dapat dikontrol melalui perlindungan kulit atau meminimalkan paparan sinar surya. Pelindung surya (photoprotection) meliputi semua cara untuk melindungi kerusakan kulit dari radiasi sinar UV, yaitu: tabir surya, pakaian, topi, berlindung di tempat teduh dan mempertimbangkan durasi serta waktu terpapar sinar surya
$(2,3,4.5)$. Menghindari sinar surya sebenarnya merupakan cara yang paling tepat untuk perlindungan kulit, namun cara ini tidak praktis. Tabir surya diketahui memberikan perlindungan terhadap paparan sinar surya, tapi pemakaiannya memberikan beberapa gangguan pada sebagian orang misalnya reaksi alergi, gangguan kosmetis, ketidak nyamanan serta biayanya mahal (5).

Pakaian dapat melindungi kulit terhadap paparan sinar surya bahkan dipandang sebagai langkah yang paling sederhana dalam mengurangi efek buruk sinar surya terhadap kulit $(2,5,6)$. Namun karena hanya sedikit petunjuk yang ada mengenai seluk beluk pakaian sebagai pelindung surya serta masih kalah populernya penggunaan pakaian sebagai pelindung surya dibanding tabir surya kimiawi, maka manfaat pakaian sebagai pelindung surya seolah hilang bila dibanding dengan fungsi estetiknya. Meskipun demikian di beberapa negara maju telah tersedia pakaian yang dinyatakan memiliki kemampuan perlindungan terhadap sinar surya tertentu. Pakaian-pakaian tersebut tentu saja mahal, namun tampaknya akan terus berkembang menjadi bisnis industri kain yang menjanjikan. Berbagai riset bahkan telah dikembangkan untuk menetapkan standar kain dan desain pakaian pelindung surya.

\section{ULTRAVIOLET DAN RADIASI TAMPAK}

Untuk memahami efek radiasi solar diperlukan sejumlah pengetahuan mengenai konsep dasar fotobiologi. Beberapa bentuk energi yang ada dibumi adalah radiasi elektromagnetik, mekanik, elektrikal, panas dan radiasi nuklir (gambar 1) (7).Radiasi elektromagnetik yang utama adalah radiasi solar yang dapat terabsorbsi, dihamburkan, dipantulkan dan dibiaskan $(7,8)$. 

Hal.

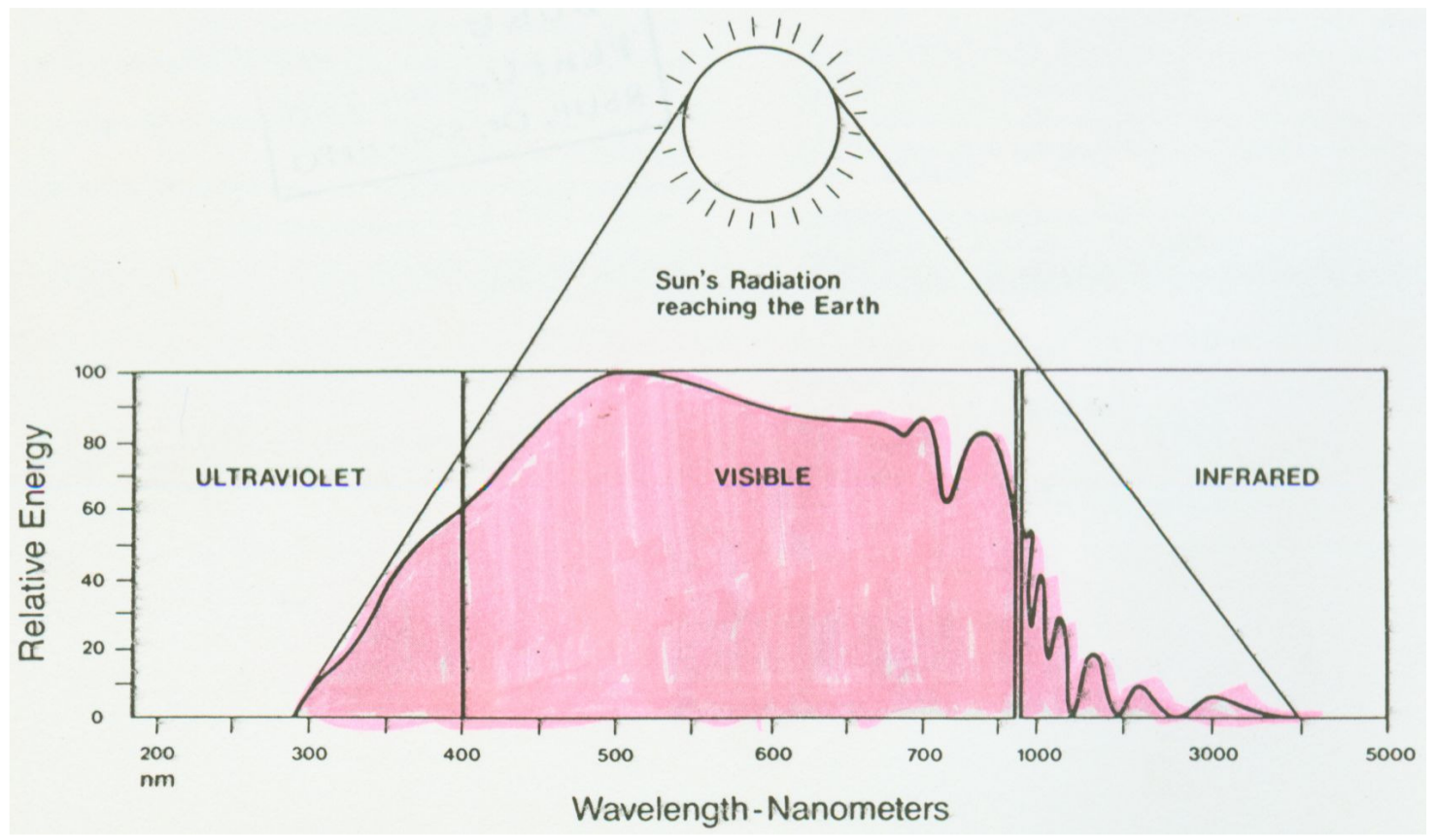

Gambar 1. Radiasi elektomagnetik sinar surya yang mencapai bumi (panjang gelombang $290-4000 \mathrm{~nm}$ ), Dikutip dari Harber et al. (9)

\section{SPEKTRUM SINAR SURYA}

Dalam fotobiologi klinis terdapat klasifikasi radiasi elektromagnetik berdasarkan panjang gelombang dan frekuensi dengan nanometer $(\mathrm{nm})$ sebagai satuan internasional ukuran panjang gelombang.

Sinar surya merupakan suatu kumpulan gelombang elektromagnetik yang terdiri atas sinar-sinar kasat mata dan sinar tidak kasat mata. Spektrumnya $99 \%$ berada pada panjang gelombang antara $270-400 \mathrm{~nm}$, mulai dari sinar ultraviolet (UV) sampai sinar inframerah. Dalam perjalanannya sampai ke bumi sinar surya harus melewati beberapa lapisan pembungkus bumi (biosfer). Oleh karena itu sinar yang sampai di bumi sudah mengalami perlemahan. Di bagian atas (stratosfer) ada lapisan ozon yang akan menyerap semua sinar dengan panjang gelombang kurang dari $296 \mathrm{~nm}$, sedang di lapisan bawah (trofosfer) sinar surya masih mengalami rintangan dengan adanya uap air, $\mathrm{CO}_{2}$, awan dan sebagainya yang merupakan pelindung dari pengaruh sinar UV yang kuat, sehingga spektrum sinar surya yang benar-benar sampai di bumi adalah sebagai berikut:

\section{Tabel 1. Spektrum sinar surya dan intensitas radiasi}

\begin{tabular}{|l|c|c|}
\hline \multicolumn{1}{|c|}{ SPEKTRUM } & $\begin{array}{c}\text { PANJANG GELOMBANG } \\
(\mathrm{nm})\end{array}$ & PERSENTASE \\
\hline UVB & $295-320$ & 0,5 \\
UVA & $320-400$ & 5 \\
Sinar kasat mata & $400-760$ & 40 \\
Inframerah & $>760$ & 54 \\
\hline
\end{tabular}

Dikutip dengan modifikasi dari Herber LC,dkk (10)
Seperti tampak pada tabel 1, maka sebenarnya sinar UV hanya merupakan sebagian kecil saja dari spektrum sinar surya. Namun sinar UV ini paling berbahaya bagi kulit karena reaksireaksi yang ditimbulkannya seperti terbakar surya sampai timbulnya kanker kulit.

Jumlah UV yang mencapai permukaan bumi dipengaruhi oleh berbagai hal, diantaranya: kondisi atmosfer dan lingkungan, waktu,dan musim $(1,8)$. Sebenarnya sinar UV baik yang berasal dari matahari maupun dari alat buatan dapat dibagi menjadi 3 yaitu: UVA, UVB dan UVC. Sinar UVC merupakan sinar yang tidak sampai ke bumi karena mengalami penyerapan. Akan tetapi seseorang dapat terkena paparan sinar UVC ini dari lampu-lampu buatan. Kelainan yang timbul yang disebabkan oleh UVC adalah kulit kemerahan, peradangan mata dan merangsang pigmentasi. Sinar UVB yang mempunyai panjang gelombang $290-320 \mathrm{~nm}$ sering disebut sebagai spektrum terbakar surya, karena sinar ini penyebab utama terjadinya terbakar surya (sunburn). UVB ini paling efektif menyebabkan pigmentasi, sedang UVA biasanya hanya menyebabkan kulit menjadi coklat, walaupun dapat juga menimbulkan terbakar surya tapi lebih lemah dibanding dengan UVB. Karena intensitas UVA yang sampai ke bumi kira-kira 10 kali UVB, maka efek kumulatif jangka panjang sinar UVA ini sama pentingnya dengan efek UVB.

\section{PENGARUH SINAR SURYA PADA KULIT}

Dalam fotokimiawi ditetapkan bahwa hanya sinar terabsorbsi yang dapat menyebabkan perubahan fotokimiawi $(6,8)$. Agar sinar UV dapat mengakibatkan perubahan dalam suatu sistem maka harus terabsorbsi dulu oleh sistem tersebut. Dalam pengertian ini energi sinar (energi elektromagnetik) dikonversi menjadi energi kimiawi dalam molekul yang mengabsorbsi sinar, selanjutnya digunakan untuk memulai 
perubahan kimiawi. Konsep ini dikemukakan oleh Grotthus \& Draper pada tahun $1818(7,9)$.

Anderson \& Parrish, 1981 menunjukkan bahwa sinar yang mengenai kulit dipantulkan sebesar $5 \%$ dan sisanya memasuki kulit melalui stratum korneum. Sepuluh persen diantaranya dihamburkan kembali keluar kulit, sedang lainnya diabsorbsi kulit dan jaringan di bawahnya sesuai panjang gelombang $(7,9)$.

Sebagian kecil efek sinar surya yang menguntungkan pada kulit diantaranya adalah fotosintesis vitamin $D$, efek bakterisidal dan efek terapeutik (10), sedangkan sebagian besar pada umumnya efeknya adalah merugikan. Secara klinis reaksi kulit terhadap UV dibagi menjadi reaksi akut dan kronis. Reaksi akut terjadi dalam beberapa jam sampai beberapa hari setelah paparan. Reaksi ini dapat terjadi apabila kulit terpapar sinar surya terus menerus dalam waktu $10-24$ jam. Makin terang kulit seseorang makin cepat timbulnya terbakar surya. Yang paling berperan dalam terbakar surya ini adalah UVB. Perubahan akut berikutnya yang mungkin terjadi adalah pigmentasi kulit, pigmentasi dapat timbul setelah paparan $24-36$ jam, yang berpengaruh pada reaksi ini terutama adalah UVA. Pigmentasi dapat juga terjadi tertunda yaitu setelah 3 hari yaitu jika sinar UVA dan atau UVB merangsang melanosit membentuk melanin. Di klinik pigmentasi ini berupa timbulnya bercak hitam pada kulit. Perubahan akut lain yang dapat terjadi adalah kerusakan DNA, RNA dan melabillkan membran lisosomal dan selular $(2,9)$. Sedang perubahan-perubahan paparan UVB yang berkepanjangan menyebabkan kerusakan jaringan ikat dermal dan merupakan stimulus karsinogenik primer untuk kanker non melanoma. Efek UVB adalah langsung, tak perlu fotosensitiser dan tak dapat menembus kaca jendela, akan tetapi bila terpapar berkepanjangan akan menyebabkan kerusakan jaringan ikat dermal dan merupakan stimulus karsinogenik primer untuk kanker nonmelanoma, sedangkan sinar UVA dapat melalui kaca jendela dan menghasilkan sejumlah efek fotobiologi yang tidak langsung karena memerlukan oksigen (10). Sinar UVA ini dibagi dalam 3 katagori yaitu: UVA, UVA I dan UVA II, yang menimbulkan respon eritema langsung dan menghilang dalam 2 jam sedang eritema lambat dalam waktu 6 jam.

Dosis eritema minimal (DEM), menggambarkan jumlah minimal radiasi UV yang mampu menimbulkan eritema. Faktor Pelindung Surya/Sun Protecting Factor (FPS/SPF) adalah pengukuran fotoproteksi dengan memakai suatu stimulator solar. Menurut Pathak et al. (1971) angka ini merupakan rasio dosis energi yang diperlukan untuk menimbulkan DEM oleh suatu tabir surya dibandingkan dengan energi yang diperlukan untuk meimbulkan DEM tanpa perlindungan. Nilai FPS akan memberikan gambaran bagi konsumen mengenai perkiraan efek proteksi kulit terhadap radiasi UVB (11).

Paparan surya perorangan tergantung pada intensitas radiasi UV, fraksi paparan pada lokasi tubuh, perilaku perorangan dan waktu saat terpapar surya. Selanjutnya dosis UV yang diabsorbsi kulit masih dipengaruhi oleh tipe kulit dan pelindung yang dikenakan seperti pakaian, topi maupun tabir surya (12).

\section{PENGETAHUAN DASAR MENGENAI KAIN}

Kain sebagai bahan sandang harus diproses sedemikian rupa sehingga memenuhi syarat dan dapat memenuhi selera pasar (13). Untuk itu para produsen industri tekstil memiliki kebiasaan mengadakan pengamatan dan penelitian terhadap selera pasar sebelum produksi berjalan. Penelitian dikerjakan baik mengenai mutu, fungsi maupun harganya. Di beberapa negara industri tekstil juga mempertimbangkan alasan kesehatan dalam produksinya termasuk memproduksi kain yang memiliki kualitas sebagai pelindung surya.

Pengetahuan mengenai kain diawali dengan mempelajari hal-hal sebagai berikut: (1), Struktur atau komposisi kain yang meliputi anyaman, lebar kain, tebal benang, bahan atau serat asal benang, dan macam kain, (2) Warna, corak atau motif kain, (3), Sifat-sifat kain, termasuk daya tahan terhadap keadaan, mutu dan lainnya, (4) Penggunaannya, (5) Cara pembuatan/prosesnya (10). Berdasarkan bahan dasar maka serat kain dapat dikelompokkan atas 2 bagian yaitu: serat asli yang berasal dari tumbuhan (serat biji, kulit, daun atau buah), hewan atau mineral seperti asbestos dan serat buatan yang dapat berasal dari tumbuhan, hewan, mineral maupun serat sintetis (10).

Kapas merupakan bahan dasar serat asli yang paling banyak dipakai di seluruh dunia. Dari serat ini dapat dibuat berbagai jenis kain yang sangat berbeda satu dari lainnya seperti cita, flanel, organdi, tenunan seperti dril atau jeans dll. Berdasarkan cara pembuatannya terdapat pembagian sederhana serat buatan sebagai berikut: (a) Dengan bahan dasar selulose (rayon, asetat), (b) Dengan bahan alami lain (benang kertas, benang karet, wol susu, benang kaca) dan (c) Melalui proses persenyawaan zat kimia, hasilnya disebut serat sintetis (serat poliamid, poliakrilik, poliester). Nylon adalah serat sintetis yang pertama kali ditemukan di Amerika, hampir semua serat sintetis dibuat dengan cara mencairkan bahan-bahan dasar biasa dengan bahan kimia, kemudian menyemprotkan campuran cairan tersebut melalui sebuah lubang. Cairan akan mengeras menjadi benang halus atau kasar sesuai kehendak pembuatnya (10).

Setiap serat memiliki keunggulan dan kekurangan dalam sifat tenunannya yang baik berkaitan dengan kelenturannya, elastisitasnya, kelembutannya, misalnya kuat, tidak lekas kusut, tidak terasa panas, lembut dan beberapa sifat lain yang disesuaikan dengan keperluan pemakainya $(1,10)$. Konsumen juga masih mempertimbangkan kain bermutu sebagai kain yang mudah perawatannya, indah tampilannya dan fungsional. Pertimbangan lain dalam memproduksi kain adalah daya absorbsinya, kebersihannya, efeknya terhadap pencucian, penyusutan, sifat jatuhnya kain, perspirasi dll. Selain mengetahui sifat tenunannya, kain dapat juga diketahui dari asal bahan dasarnya misalnya dengan cara memeriksa panjang serat, kilau serat, daya mulurnya dan kehalusannya. Untuk memastikannya maka dapat dilakukan dengan cara membakar atau membasahi kain tersebut (10).

\section{KAIN DAN PAKAIAN SEBAGAI PELINDUNG SURYA}

Kain dalam fungsinya sebagai pakaian telah lama digunakan sebagai bagian dalam upaya perlindungan terhadap paparan surya bahkan sebagian ahli menyatakan pakaian sebagai mode utama namun sederhana dalam perlindungan terhadap sinar surya $(5,6)$. Meskipun demikian pertanyaan mengenai jenis kain yang efektif belum juga terjawab secara memuaskan. Secara umum petunjuk medis akan memilihkan kaos berlengan panjang, celana panjang dan topi bertepi lebar yang seluruhnya terbuat dari kain tenunan rapat sebagai pelindung surya yang memadai (6). Dengan demikian sebanyak mungkin badan tertutup pakaian maka akan terhindarlah 
Hal.

seseorang dari efek buruk paparan sinar surya. Tentunya hal ini kurang praktis dan cukup mengganggu bagi seseorang yang senang mengikuti perkembangan mode maupun mereka yang gemar dengan kegiatan di udara terbuka. Oleh karena itu dikembangkan berbagai riset yang menyelidiki transmisi sinar UV melalui kain baik secara in vivo, radiometrik dan spektrofotometrik (5). Pada umumnya riset-riset tersebut mencoba menetapkan sifat bahan berdasarkan perbedaan berat, jumlah, kelembaban, warna, tercuci atau tidak (14). Data diambil dari data transmisi UV, iradiasi dan spektrum kerja eritema. Respon eritema biasanya dipakai sebagai dasar evaluasi sifat pelindung surya suatu kain, baik melalui transmisi langsung maupun uji foto langsung.

\section{Faktor Pelindung Surya Kain \& Pakaian}

Di Australia pada tahun 1992, Gies memperkenalkan konsep perlindungan surya (Protection Factor/PF) oleh pakaian dan menyebutnya sebagai Ultra Violet Protection Factor (UPF) $(6,15,16)$. Istilah ini analog dengan Fabric Protection Factor (FPF) dan Relative Protection Factor (RPF). Kekuatan suatu pelindung surya dilihat dengan cara mengukur besarnya UPF/PF. Konsep ini bermanfaat dalam mempelajari kemampuan pakaian atau kain terhadap paparan surya serta memberikan informasi kepada konsumen mengenai perkiraan perlindungan kulit terhadap paparan surya, sehingga kain dengan UPF 10 adalah setara dengan tabir surya SPF 107. Industri pakaian yang mencantumkan UPF dalam bentuk label pakaian menuliskan pula pesan-pesan bahaya paparan surya yang berlebihan di sisi balik label tersebut. Untuk masyarakat umum diketengahkan skema UPF sebagai berikut:

\section{Tabel 2. Rangkuman Faktor Proteksi Ultraviolet Kain}

\begin{tabular}{|c|l|l|}
\hline $\begin{array}{c}\text { FAKTOR PROTEKS } \\
\text { ULTRAVIOLET }\end{array}$ & $\begin{array}{c}\text { RATA-RATA } \\
\% \text { TRANSMISI UV }\end{array}$ & KATAGORI PROTEKSI \\
\hline UPF $40+$ & $<2,5$ & Proteksi maksimum \\
UPF $30-39$ & $3,3-2,5$ & Proteksi sangat tinggi \\
UPF $20-29$ & $5,0-3,3$ & Proteksi tinggi \\
\hline
\end{tabular}

Dikutip dari Bendes K (16)

Faktor UPF ini tergantung dari kemampuan penetrasi UV melalui kain, terutama transmisi langsung melalui lubang/celah diantara tenunan seratnya dan bukan melalui penetrasi pada kain (6). Dalam penelitian Lowe (1998), diketahui bahwa kain yang secara in vitro memiliki UPF kurang dari 15 ternyata memang gagal dalam mencegah timbulnya eritema pada penelitian in vivo (7). Eritema baru terlindungi bila secara in vitro UPF kain menunjukkan nilai 31 (5). Konsep mutakhir fotoproteksi juga merekomendasikan pakaian dengan UPF minimal $30(2,6)$. Orang dengan aktifitas di udara terbuka dan mengenakan kaos yang memiliki UPF rata-rata 7 serta tidak memakai tabir surya termasuk tindakan yang tidak megedepankan langkah perlindungan surya. Diusulkannya standar minimum UPF sebesar 40 sampai 50. Selain itu ada pendapat yang menyatakan bahwa pakaian dengan nilai proteksi rendahpun memiliki kemampuan perlindungan UVA dan UVB yang lebih baik dari pada tabir surya kimiawi (10). Diffey (1998) menyatakan bahwa sebagian besar tipe kain menghasilkan perlindungan yang baik terhadap semua spektrum radiasi UV (4). Kemampuan ini serupa dengan perlindungan UV kumulatif yang dihasilkan dari tempat teduh, payung, topi dengan tepi lebar dan kanopi (10).

Pathak (1993) menyatakan bahwa transmisi UV melalui kain dipengaruhi oleh metode penyusun misalnya sela antar benang / kerapatan tenunan, tipe serat, warna, bahan-bahan yang ditambahkan pada kain tersebut, serta proses penyempurnaannya. Bandes (1999) menambahkan unsur keadaan tercuci atau tidak menjadi faktor yang mempengaruhi kemampuan perlindungan surya suatu pakaian $(16,18)$.

\section{Faktor serat atau struktur kain}

Serat tenunan atau rajutan yang rapat dengan sela antar benang yang kecil memiliki UPF yang lebih tinggi bila dibandingkan kain berserat longgar $(2,17)$. Densitas serat ini bahkan lebih utama bila dibandingkan dengan jenis kainnya sendiri (2). Kelonggaran serat kain dapat dilihat dengan menerawangkan kain tersebut ke arah sumber sinar. Seluruh katun putih, linen, asetat dan rayon memiliki UPF kurang dari 15 , sedangkan poliester memiliki UPF yang lebih tinggi $(5,18)$. Kain dengan serat sintetis kurang transparan terhadap UVB dan UVA bila dibanding dengan katun, sehingga memiliki kemampuan lindung yang lebih baik. Rajut dengan serat khusus diproduksi untuk yang gemar berjemur, karena dapat mencegah sinar-sinar eritemogenik.

\section{Berat atau masa kain}

UPF diketahui juga dipengaruhi oleh meningkatnya masa atau berat kain (5). Faktor ini bukan merupakan unsur yang dominan, mengingat faktor serat/struktur dan warna dapat memberikan perbedaan kemampuan proteksi kain.

\section{Warna kain}

Warna gelap pada kain akan memberikan perlindungan surya yang lebih tinggi daripada warna terang. Lowe, et all (1998) dan Pathak et al (1993) juga mendukung bahwa proteksi UV lebih baik pada pakaian dengan warna gelap bahkan disebutkan bahwa hitam sangat baik untuk mencegah radiasi UV ke kulit, tapi karena sekaligus menyerap sinar kasat mata dan infra merah maka warna hitam tidak nyaman dipakai (11). Orang-orang di Timur Tengah mengenakan pakaian warna putih yang menutup hampir seluruh badan. Kebiasaan ini mampu menyerap kurang lebih $80 \%$ radiasi UV dan memendarkan $10 \%$ nya.

\section{Kain dan Desain Pakaian}

Perlindungan terhadap paparan surya selain dipengeruhi jenis kain maka juga terdapat manfaat dari desain pakaian dan perangkat penunjang yang menyertainya misalnya pada penggunaan topi, payung, stocking dll. Perlindungan terhadap mata dan kulit sekitarnya juga penting diantaranya dengan mengenakan kacamata hitam, kacamata renang, helm tertentu, payung dan lain-lain $(5,15,11)$.

Bagi penderita fotosensitif maka wajah adalah bagian badan yang sangat mudah terkena sehingga perlu dilindungi denga topi. Diffey (1992) membagi 4 jenis topi yaitu: bertepi kecil $(<2,5 \mathrm{~cm})$, medium $(2,5-7 \mathrm{~cm})$, besar $(>7,5 \mathrm{~cm})$ dan peaked cap. Seluruh tipe topi memberikan perlindungan yang baik untuk dahi. Bagi orang yang tinggal di daerah panas, dianjurkan dengan tepi $>7,5 \mathrm{~cm}$ agar dapat melindungi area sekitar hidung dan pipi sebagai lokasi tersering timbulnya kanker nonmelanoma (4). 
Penyakit Bowen, karsinoma sel basal dan karsinoma sel skuamosa, serta melanoma maligna lebih banyak timbul pada kaki wanita daripada laki-laki, hal ini diperkirakan karena pola pakaian pria dan wanita yang berbeda. Penelitian tentang stocking menunjukkan bahwa jenis stocking yang paling populer hanya memiliki UPF kurang dari 2, sedang yang terbuat dari kain denim, twill atau lycra diperkirakan memiliki UPF lebih dari 50. Untuk itu disarankan agar para wanita yang memerlukan pelindung surya mengenakan stocking dari bahan tersebut atau mengenakan celana panjang (19). Selain itu perlu mewaspadai penurunan UPF stocking, bila pada pemakaian diregangkan (20).

\section{Kain dan Air}

Kain yang basah (karena berkeringat atau saat berenang) dapat mempengaruhi potensi pelindung surya $(2,12)$. Keadaan ini berlaku untuk kain jenis katun, sedangkan untuk jenis poliester, oleh karena itu keadaan basah dapat menaikkan ataupun menurunkan nilai UPF kain. Pakaian yang telah dicuci berulang kali juga memiliki kemampuan pelindung surya lebih rendah $(2,7,11)$.

\section{Kampanye Pakaian sebagai Pelindung Surya}

Di Amerika Serikat pada tahun 1989 dikeluarkan konsensus untuk mengurangi risiko paparan surya dengan langkah-langkah, yaitu menggunakan pakaian yang tepat, penggunaan produk tabir surya fisik dan kimiawi, meningkatkan perilaku mengurangi paparan surya, berhati-hati terhadap pengobatan fotosensitif dan waspada terhadap efek samping paparan surya (1). Senada dengan konsensus tersebut maka di banyak negara lainnya didapatkan program untuk mengurangi risiko paparan surya yang meliputi: (a) Menghindari paparan surya saat radiasi UV yang paling tinggi yaitu antara pukul 10.00 sampai pukul 16.00 , (b) Menutup badan dengan pakaian yang tepat serta (c) memakai tabir surya (21).

Dari berbagai bukti maka pada tahun 1999 the American Academy of Dermatology menyatakan peningkatan kanker kulit disebabkan karena paparan surya yang belebihan. Untuk menyikapi hal tersebut dilakukan penyempurnaan upaya pencegahan, diantaranya melalui program kampanye perlindungan surya dengan rekomendasi seperti pada tabel berikut.

Tabel 3. Rekomendasi Pencegahan Primer Risiko Paparan Surya

A. Batasi paparan radisi UV, terutama antara pukul 10.00 sampai pukul 16.00

B. Memakai pakaian dan kacamata matahari yang tepat

C. Memakai tabir surya (SPF 15 atau lebih) termasuk pemoles bibir

D. Hindari alat-alat menggosong kulit

E. Anak-anak bawah usia 6 bulan memakai topi, berlindung di tempat teduh, bukan memakai tabir surya

Semangatkan anak-anak untuk mempraktekkan shadow rule, cari tempat teduh

F. Preservasi lapisan ozon

Dikutip dari Lim HW, Cooper K (12)

Mengingat paparan surya selama masa kanak-kanak sangat erat kaitannya dengan peningkatan tumbuhnya nevus melanositik, yang merasakan suatu prediktor untuk risiko melanoma maka strategi kampanyenya harus ditujukan pada anak juga. Dari data statistik setengah usia kehidupan manusia yang terpapar UV adalah sebelum usia 18 tahun. Pada anak-anak terbakar surya yang menimbulkan lepuh walaupun hanya 1 buah akan meningkatkan risiko keganasan kulit pada usia dewasa sebesar 2 kali. Kenyataannya bila anak-anak terlindung dari UV sampai usia 12 tahun maka lebih dari $80 \%$ risiko keganasan kulit pada usia dewasa dapat dihindari. Dalam beberapa tahun terakhir ini banyak dikembangkan penelitian-penelitian risiko paparan sinar surya kaitannya dengan risiko keganasan pada populasi anak, yang pada kesimpulannya menyarankan metode-metode perlindungan paparan surya termasuk mengenakan pakaian dan topi yang tepat $(4,18,21)$.

\section{DAFTAR PUSTAKA}

9. Bickers, D.R., Parrish, J.A., Lowe, N.J., National Institutes of Health Summary of the Consensus Development Conference on Sunlight, Ultraviolet Radiation and the Skin. Maryland Consensus Development Panel 1989; J Am Acad Dermatol. 1991: 24: 608612.

10. Kaminester, K.H., Current Concepts: Photoprotection. Arch Fam Med. 1996: 5: 289-295.

11. Mc Leahn, D.I., Gallagher, R., Sunscreen: Use and Misuse. Dermatology Clinics .1998: 16: 219-225.

12. Diffey, B.I., Cheesman, J., Sun Protection With Hats. British J of Dermatol. 1992: 127: 10-12.

13. Davis, S., Capjack, L., Kerr, N., Fedosejevs, R., Clothing As Protection From Ultraviolet Radiation: Which Fabrics Is Most Effective? Int J Dermatol. 1997: 36: 374-379.

14. Kimlin, M.G., Paresi, A.V., Meldrum, L.R., Effect of Strech on The Ultraviolet Spectral Transmission of One Type Commonly Used Clothing. Photodermal Photoimmunol Photomed. 1999: 15: 171-71

15. Bech-Thomson, N., Walf, H.C., Ullman, S., Xeroderma Pigmentosum Lesions Related to Ultraviolet Transmitance by Clothes. J Am Acad Dermatol. 1991: 24: 365-368.

16. Menter, J.M., et al., Protection Against UV Photocarcinogenesis by Fabrics Material, J Am Acad Dermatol. 1994: 31: 711-716.

17. Lowe, Nj., Bourget, T.D., Hughes, S., Sayre, R.M., Ultraviolet Protection Offered By Clothing: An In Vitro and In Vivo Assesment of Clothing Fabrics. In: NJ Lowe, NA Shaath, MA Pathak, eds). Sunscreen Development, Evaluation and Regulatory Aspect 2 nd ed. Marcel Dekker Inc. New York. 1998: 619-629.

18. Harber, L.C., Bickers, D.R., Kochevar, I., Lamola, A., Introduction to Ultraviolet and Photobiology In: LC Haebe, DR Bickers. Photosensitivity Diseases. Principles Diagnosis and Tratment 2nd ed BC Decker Inc. Philadelphia. 1989: $12-24$. 
Hal.

19. Honingsmann, H., Szeimies, R.M., Knobler, R., Fitzpatrtick, T.B.., Pathak, M.A., Wolff, K., Photochemistry and Photodynamic Therapy. In: TB Fitzpatrick., AZ Eise, K Wolff, IM Freedberg, KF Austen, eds. Dermatology in General Medicine $5^{\text {th }}$ ed. Mc GrawHill Inc. New York. 1999: 2880-2900.

20. Lim, H.W., Cooper, K., (ed). The Health Impact of Solar Radiation and Prevention Strategies. J Am Acad Dermatol. 1999: 41: 81 102.

21. Diffey, B.L., Human Exposure to Ulraviolet Radiation, In: JLM Hawh ed. Photodermatology 1st ed. Arnold, London. 1999.

22. Yayasan Pembonaan Keluarga UPN Veteran. Pengetahuan dasar Tentang Kain-kain Tekstil dan Pakaian Jadi., Yogyakarta. 1984.

23. Van Paassen, W.J.G., Ruygrok, J.R., Sjahrial, R.P., Pengetahuan Barang Tekstil Sederhana. Pradnya Paramata. Jakarta. 1977.

24. Bandes, K., Under the Sun: Solar Protecctive Fabrics Are Not A; The Same. J of Family and Costumer service. 1999: 91(4) 91-95 (abs).

25. Greiter, F., Bilek P., Doskoczil. History of Sunscreen and The Rationale for Their Use. Practice of Dermatology $2^{\text {nd }}$ ed. McGraw Hill Co. New York. 1993: 187-206

26. Pathak, M,A., Fitzpatrick, T.B., Prevention Treatment of Sunburn, Dermatoheliosis and skin Cancer with Sun Protective Agents. In: TB Fitzpatrick, AZ Eise, K Wolff, IM Freedberg, KF Austen, eds. Dermatology in General Medicine ${ }^{4}$ th ed. Mc Graw-Hill Inc.New York. 1993: 1689-1716.

27. Sinclair, S.A., Diffey, B.L., Sun Protection Provided by Ladies Stockings. Br J dermatol. 1997: 136: 239-241.

28. Turner, M., Sun safety: Avoiding Noonday Sun, Wearing Protective Clothing and the Use of Sunscreen. J of Nat Cancer Ins. 1998: 90 (25): 1854-1855.

29. Buller, D.B., Buller, M.K., Beach, B., Ertl, G., Sunny Days, Healthy Ways: Evaluation of a Skin Cancer Prevention Curriculum for Elementary School-aged Childern, J Am Acad Derrmatol. 1996: 35: 911-922. 